\title{
Journal of

\section{Design, Synthesis, and Biological Evaluation of Imidazo[1,5-a]quinoline as Highly Potent Ligands of Central Benzodiazepine Receptors}

Andrea Cappelli, ${ }^{* \dagger}$ Maurizio Anzini, ${ }^{*}{ }^{\dagger}$ Federica Castriconi, ${ }^{\dagger}$ Giorgio Grisci, ${ }^{\dagger}$ Marco Paolino, ${ }^{\dagger}$ Carlo Braile, ${ }^{\dagger}$ Salvatore Valenti, ${ }^{\dagger}$ Germano Giuliani, ${ }^{\dagger}$ Salvatore Vomero, ${ }^{\dagger}$ Angela Di Capua, ${ }^{\dagger}$ Laura Betti, ${ }^{\ddagger}$ Gino Giannaccini, ${ }^{\ddagger}$ Antonio Lucacchini, ${ }^{\ddagger}$ Carla Ghelardini, ${ }^{\S}$ Lorenzo Di Cesare Mannelli, ${ }^{\S}$ Maria Frosini, Lorenzo Ricci," Gianluca Giorgi, ${ }^{\dagger}$ Maria Paola Mascia, ${ }^{\perp}$ and Giovanni Biggio ${ }^{\perp}$

${ }^{\dagger}$ Dipartimento di Biotecnologie, Chimica e Farmacia and European Research Centre for Drug Discovery and Development, Università degli Studi di Siena, Via A. Moro 2, 53100 Siena, Italy

"Dipartimento di Farmacia, Università di Pisa, Via Bonanno 6, 56126 Pisa, Italy

${ }^{\S}$ Dipartimento di Neuroscienze, Psicologia, Area del Farmaco e Salute del Bambino (NEUROFARBA), Sezione Farmacologia e Tossicologia, Università di Firenze, Viale G. Pieraccini 6, 50139 Firenze, Italy

"Dipartimento di Scienze della Vita, Università degli Studi di Siena, Via A. Moro 2, 53100 Siena, Italy

${ }^{\perp}$ Istituto di Neuroscienze, Consiglio Nazionale delle Ricerche, Cittadella Universitaria, S.S. 554-Km 4.500, 09042 Monserrato Cagliari, Italy

\section{Supporting Information}

ABSTRACT: A series of imidazo[1,5-a]quinoline derivatives was designed and synthesized as central benzodiazepine receptor (CBR) ligands. Most of the compounds showed high CBR affinity with $K_{\mathrm{i}}$ values within the submicromolar and subnanomolar ranges with interesting modulations in their structure-affinity relationships. In particular, fluoroderivative $7 \mathbf{w}\left(K_{\mathrm{i}}=0.44 \mathrm{nM}\right)$ resulted in the most potent ligand among the imidazo[1,5- $a$ ]quinoline derivatives described so far. Overall, these observations confirmed the assumption concerning the presence of a large though apparently saturable lipophilic pocket in the CBR binding site region interacting with positions 4 and 5 of the imidazo[1,5-a] quinoline nucleus.

The in vivo biological characterization revealed that compounds $\mathbf{7 a}, \mathbf{c}, \mathbf{d}, \mathbf{l}, \mathbf{m}, \mathbf{q}, \mathbf{r}, \mathbf{w}$ show anxiolytic and antiamnestic activities without the unpleasant myorelaxant side effects of the classical 1,4-BDZ. Furthermore, the effect of 7l,q,r, and 8i in lowering lactate dehydrogenase $(\mathrm{LDH})$ release induced by ischemia-like conditions in rat brain slices suggested neuroprotective properties for these imidazo[1,5-a]quinoline derivatives.

\section{INTRODUCTION}

The neurotransmitting action of $\gamma$-aminobutyric acid (GABA) at the $\mathrm{GABA}_{\mathrm{A}}$ chloride channel complex modulates the excitability of many central nervous system (CNS) pathways. ${ }^{1}$ $\mathrm{GABA}_{\mathrm{A}}$ receptors are ligand-gated ion channels (LGICs) belonging to the Cys-loop superfamily, the same as nicotinic acetylcholine, glycine, zinc-activated, and $5-\mathrm{HT}_{3}$ receptors. Cysloop receptors are characterized by the assembly of five subunits, which form pentameric arrangements around a central ion-conducting pore and are the targets of many drugs. ${ }^{1}$ The function of $\mathrm{GABA}_{\mathrm{A}}$ receptors is regulated, in addition to the agonist binding site, by allosteric sites interacting with a large variety of agents. ${ }^{2}$ Positive modulators of the GABA $\mathrm{A}_{\mathrm{A}}$ receptors, such as the classical 1,4-benzodiazepine (BDZ) diazepam (1, Figure 1), are therapeutically employed as sedatives, muscle relaxants, anxiolytics, and anticonvulsants, whereas negative<smiles>[R]c1c(N2CCNCC2)nc2ccccc2c1[R]</smiles>

6

Serotonin $5-\mathrm{HT}_{3}$ Receptor Ligands<smiles>[R]c1c([R])c2c([R])ncn2c2ccccc12</smiles>

7-9

Benzodiazepine Receptor Ligands
$\mathrm{GABA}_{\mathrm{A}}$ modulators (i.e., BDZ inverse agonists) show anxiogenic and convulsant effects. ${ }^{3-6}$ Finally, neutral modulators, such as the imidazo[1,5-a][1,4] benzodiazepines flumazenil (2), bind to $\mathrm{GABA}_{\mathrm{A}}$ receptor but have no intrinsic activity at the central benzodiazepine receptor (CBR). Thus, flumazenil is recognized to antagonize the activity of both positive and negative $\mathrm{GABA}_{\mathrm{A}}$ modulators acting via the $\mathrm{CBR}$.

Because positive modulators show amnesic effects in animal and $\operatorname{man},{ }^{7-10}$ negative modulators were assumed to possess procognitive properties. ${ }^{11,12}$ However, the use of nonselective CBR inverse agonists in the treatment of neurological disorders associated with cognitive impairment was limited by their anxiogenic and convulsant effects. ${ }^{13}$

Received: January 8, 2016

Published: March 16, 2016 


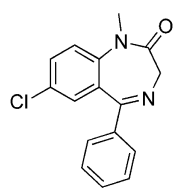

diazepam (1)<smiles>[R6]c1ccc2c(c1[R5])N([R4])C([R])([R])c1ncn-2c1[R]</smiles><smiles>CCOC(=O)c1ncn2c1CN(C)C(=O)c1cc(F)ccc1-2</smiles>

flumazenil (2)

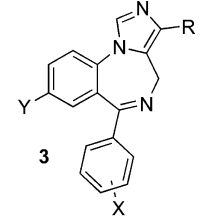

$\mathrm{R}$ : COOEt, COOtBu, CN, CONH $\mathrm{X}: \mathrm{H}, \mathrm{F}, \mathrm{Cl}, \mathrm{CH}_{3}, \mathrm{OCH}_{3}, \mathrm{NO}_{2}$ $\mathrm{Y}: \mathrm{H}, \mathrm{F}, \mathrm{Cl}$

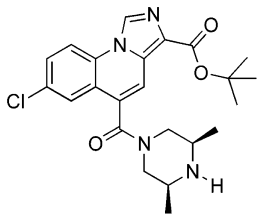

PNU-101017 (5)
Figure 1. Structure of reference compounds.

A large number of subunits (i.e., $\alpha_{1-6}, \beta_{1-4}, \gamma_{1-4}, \delta, \varepsilon, \pi, \theta$, and $\rho_{1-3}$ ) has been cloned and sequenced, but most of GABA receptors are composed of $\alpha, \beta$, and $\gamma$-subunits arranged in a 2:2:1 stoichiometry. $^{14}$ In fact, among the multitude of theoretically possible combinations deriving from the coassembly of the subunits, only the receptor subtypes containing a $\gamma_{2}$ or $\gamma_{3}{ }^{15}$ subunit in conjunction with $\alpha_{1}, \alpha_{2}, \alpha_{3}$, or $\alpha_{5}$ appear to bind BDZ ligands with significant affinity. The CBR binding domain is assumed to be located at the interface between $\alpha$ and $\gamma$ subunits, which contribute to the building of the active site with their amino acid residues. ${ }^{16}$ Investigations based on molecular genetic or pharmacological approaches suggested that $\alpha_{1}$ subunit is involved in the sedative and muscle relaxant effects of the nonselective BDZ agonists, whereas $\alpha_{2}$ or $\alpha_{3}$ can be responsible for the anxiolytic and anticonvulsant effects. ${ }^{17-19}$ The recognition of the pharmacological and physiological roles of $\alpha$ subunits in $\mathrm{GABA}_{\mathrm{A}}$ receptor subtype functions has stimulated new interest in this receptor system as the target for the development of drugs showing fewer side effects with respect to the classical benzodiazepines (e.g., nonsedating anxiolytics) or possessing different indications with respect to the classical benzodiazepines (e.g., analgesics, cognitionenhancing drugs). ${ }^{20-27} \mathrm{~A}$ number of compounds has been developed that show $\mathrm{GABA}_{\mathrm{A}}$ receptor subtype selectivity. ${ }^{20}$ In particular, subtype-selective $\mathrm{GABA}_{\mathrm{A}}$ receptor ligands were obtained either by selective binding (i.e., by forming a receptor-ligand complex with a particular receptor subtype) or by selective efficacy (i.e., by eliciting a biological response after binding to the receptor). These two properties are both important in defining the potency profile. ${ }^{20}$

Very interestingly, the full range of intrinsic efficacies observed in the series of imidazo[1,5- $a][1,4]$ benzodiazepine derivatives 3 was modulated in a rather subtle manner by the substitution pattern. ${ }^{28,29}$ A similar behavior was observed when the seven-membered ring of the benzodiazepine system was contracted as in the series of imidazo[1,5-a]quinoxaline derivatives 4, which were developed in the 1990s in Upjohn laboratories. ${ }^{30-35}$ The large body of work performed by the Upjohn researchers led to the proposal of the existence of a second low affinity-binding site on $\mathrm{GABA}_{\mathrm{A}}$ receptors, the occupancy of which (at high drug concentrations) may reverse the positive allosteric action on CBR and potentially minimize dependence and abuse liability. ${ }^{36}$

Among the large number of imidazo[1,5-a]quinoxaline derivatives developed, compound $\mathbf{4 a}$ (see Figure 1) was shown to induce a negative allosteric modulation via this second low affinity binding site. ${ }^{36}$ On the basis of the huge amount of structure-activity relationship (SAR) data on imidazo $[1,5-a]$ quinoxaline derivatives 4 , the structure of 4 a was easily translated into the imidazo[1,5-a]quinoline one of 5 (see Figure 1), which was considered as a drug candidate for the treatment of anxiety, but its development was discontinued for safety reason (i.e., centrally mediated respiratory depression having lethal effects). ${ }^{37}$ The identification of $\mathbf{5}$ as a candidate for development studies was apparently performed among a limited set of imidazo[1,5-a]quinoline derivatives so that the available SAR data on this class of CBR ligands is limited. In general, the analysis of the available SAR data suggested that bulky substituents are tolerated by CBR binding site when they are located in the ligand region corresponding to positions 4 and 5 of the imidazo[1,5- $a]$ quinoline nucleus consistently with the results obtained with $5-\mathrm{HT}_{3}$ receptor ligands based on quinoline structure $\mathbf{6}^{38,39}$ Similarly, these bulky substituents appeared to play a role in modulating the intrinsic efficacy. ${ }^{39}$ These observations, together with the structural analogies existing between $\mathrm{GABA}_{\mathrm{A}}$ and $5-\mathrm{HT}_{3}$ receptors, led us to apply the approach used in studying $5-\mathrm{HT}_{3}$ receptors to the characterization of CBR binding features by means of the design, synthesis, and pharmacological characterization of imidazo $[1,5-a]$ quinoline derivatives 7,8 , and 9 in comparison with reference imidazo[1,5-a]quinoxalines 10 (Figure 2).

\section{RESULTS AND DISCUSSION}

Chemistry. The preparation of target imidazo[1,5-a]quinoline derivatives was performed by imidazo-annulation of

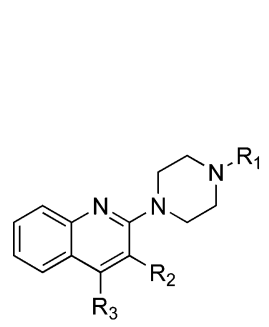

6

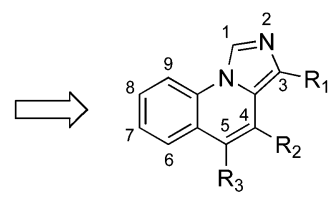

$7-9$

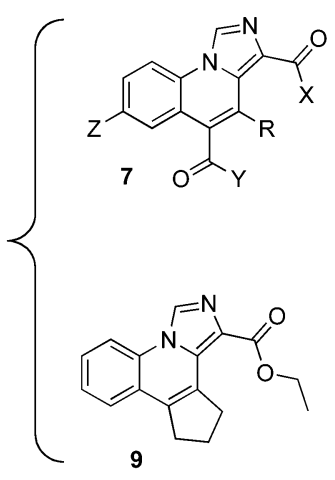<smiles>[X]C(=O)c1ncn2c1c([R])c(-c1ccccc1)c1ccccc12</smiles><smiles>[R]OC(=O)c1ncn2c1CN(C(C)=O)c1cc([X])ccc1-2</smiles>

Figure 2. Design of imidazo[1,5-a] quinoline 7-9 starting from piperazinylquinoline $5-\mathrm{HT}_{3}$ receptor ligands 6. 
suitable 2-chloroquinoline derivatives 11-24 with ethyl isocyanoacetate or tert-butyl isocyanoacetate in the presence of potassium tert-butoxide providing $7 \mathbf{a}-\mathbf{i}, \mathbf{k}-\mathbf{m}, \mathbf{o}-\mathbf{y}$ (Scheme 1 ) in the yields reported in Table 1 . The structure of $7 \mathbf{p}, \mathbf{s , t}$ was confirmed by crystallographic studies (see Supporting Information).

Scheme 1. Imidazo-Annulation of 2-Chloroquinoline Derivatives 11-24 to Target Imidazo[1,5-a]quinoline Derivatives $7 \mathrm{a}-\mathrm{i}, \mathrm{k}-\mathrm{m}, \mathrm{o}-\mathrm{y}^{a}$<smiles>[Y]C(=O)c1c(I)c(I)nc2ccc([Z])cc12</smiles>

$11-24$

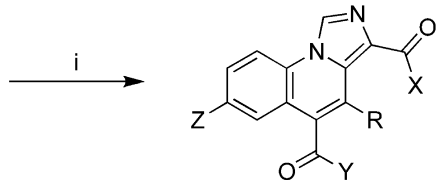

7a-i,k-m,o-y
${ }^{a}$ Reagents: (i) $\mathrm{CNCH}_{2} \mathrm{COOC}_{2} \mathrm{H}_{5}$ or $\mathrm{CNCH}_{2} \mathrm{COOC}\left(\mathrm{CH}_{3}\right)_{3}$, tertBuOK, DMF. Substituents: see Table 1.

The starting 2-chloroquinoline derivatives were either compounds known (see Table 1) or prepared by standard methodology. ${ }^{38,40}$ On the other hand, target propargylamide derivative $7 \mathbf{n}$ was synthesized from tert-butyl ester $7 \mathbf{k}$ via acid $7 \mathbf{j}$ (Scheme 2).

Acyl chloride $25^{38}$ was reacted with potassium tert-butoxide in dry THF to obtain ester 16, which was used in the abovedescribed imidazo-annulation with ethyl isocyanoacetate, affording diester $7 \mathbf{k}$. The cleavage of the tert-butyl ester moiety of the latter with formic acid gave the expected carboxylic acid $7 \mathbf{j}$, which was in turn transformed via acyl chloride into the expected propargylamide $\mathbf{7 n}$.

The target imidazo[1,5-a]quinoline derivatives bearing substituents in position 7 of the tricyclic nucleus was carried out as outlined in Scheme 3.
Scheme 2. Synthesis of Target Derivatives $7 \mathrm{j}, \mathrm{k}, \mathrm{n}^{a}$
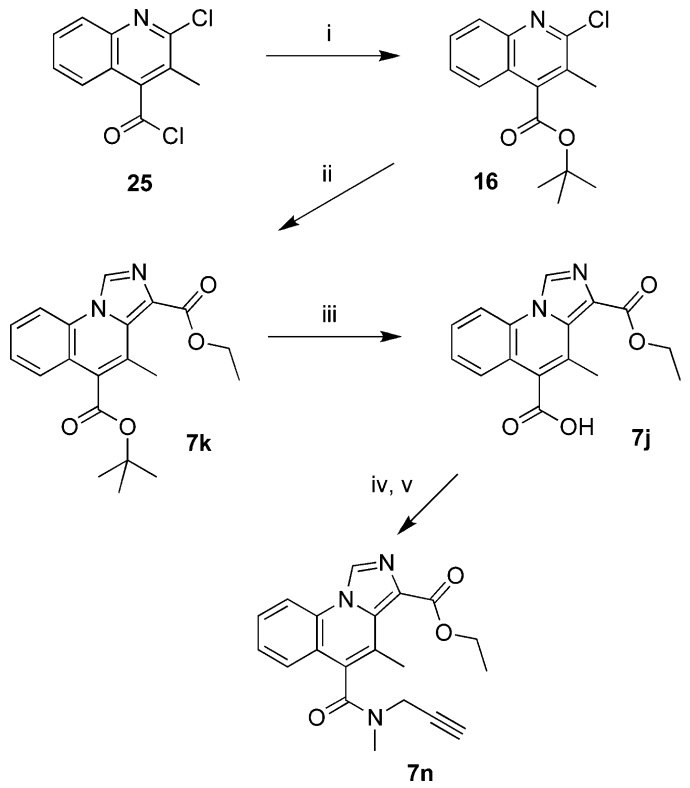

${ }^{a}$ Reagents: (i) tert-BuOK, THF; (ii) $\mathrm{CNCH}_{2} \mathrm{COOC}_{2} \mathrm{H}_{5}$, tert-BuOK, DMF; (iii) $\mathrm{HCOOH}$; (iv) $\mathrm{SOCl}_{2}$; (v) $\mathrm{N}$-methylpropargylamine, $\mathrm{CH}_{2} \mathrm{Cl}_{2}$.

The appropriately substituted quinolinone derivatives $26 \mathbf{a}, \mathbf{b}^{41}$ were converted into the corresponding 2-chloroquinoline derivatives $\mathbf{2 7} \mathbf{a}, \mathbf{b}$ by reaction with phosphorus oxychloride. The amidation of the carboxyl group of $27 \mathbf{a}, \mathbf{b}$ afforded the expected amides 22-24, which were used in the abovedescribed imidazo-annulation with ethyl isocyanoacetate or tertbutyl isocyanoacetate to obtain target compounds $7 \mathbf{w}, \mathbf{x}, \mathbf{y}$. Bromoderivative $7 \mathbf{y}$ was then used in Sonogashira coupling

Table 1. Preparation of Target Compounds $7 a-i, k-m, o-y$

\begin{tabular}{|c|c|c|c|c|c|c|c|}
\hline target & $\mathrm{X}$ & $\mathrm{Y}$ & $\mathrm{Z}$ & $\mathrm{R}$ & starting & source & yield (\%) \\
\hline $7 a$ & $\mathrm{OC}_{2} \mathrm{H}_{5}$ & $\mathrm{~N}\left(\mathrm{CH}_{3}\right)_{2}$ & $\mathrm{H}$ & $\mathrm{H}$ & 11 & Experimental Section & 35 \\
\hline $7 \mathbf{b}$ & $\mathrm{OC}\left(\mathrm{CH}_{3}\right)_{3}$ & $\mathrm{~N}\left(\mathrm{CH}_{3}\right)_{2}$ & $\mathrm{H}$ & $\mathrm{H}$ & 11 & Experimental Section & 59 \\
\hline $7 \mathrm{c}$ & $\mathrm{OC}_{2} \mathrm{H}_{5}$ & $\mathrm{~N}\left(\mathrm{CH}_{3}\right) n-\mathrm{C}_{4} \mathrm{H}_{9}$ & $\mathrm{H}$ & $\mathrm{H}$ & 12 & Experimental Section & 10 \\
\hline $7 d$ & $\mathrm{OC}\left(\mathrm{CH}_{3}\right)_{3}$ & $\mathrm{~N}\left(\mathrm{CH}_{3}\right) n-\mathrm{C}_{4} \mathrm{H}_{9}$ & $\mathrm{H}$ & $\mathrm{H}$ & 12 & Experimental Section & 17 \\
\hline $7 e$ & $\mathrm{OC}_{2} \mathrm{H}_{5}$ & $\mathrm{~N}\left(n-\mathrm{C}_{3} \mathrm{H}_{7}\right)_{2}$ & $\mathrm{H}$ & $\mathrm{H}$ & 13 & see $\operatorname{ref} 38$ & 72 \\
\hline $7 f$ & $\mathrm{OC}\left(\mathrm{CH}_{3}\right)_{3}$ & $\mathrm{~N}\left(n-\mathrm{C}_{3} \mathrm{H}_{7}\right)_{2}$ & $\mathrm{H}$ & $\mathrm{H}$ & 13 & see ref38 & 48 \\
\hline $7 g$ & $\mathrm{OC}_{2} \mathrm{H}_{5}$ & $\mathrm{~N}\left(\mathrm{CH}_{3}\right) \mathrm{CH}_{2} \mathrm{C}_{6} \mathrm{H}_{5}$ & $\mathrm{H}$ & $\mathrm{H}$ & 14 & see ref38 & 56 \\
\hline $7 \mathbf{h}$ & $\mathrm{OC}\left(\mathrm{CH}_{3}\right)_{3}$ & $\mathrm{~N}\left(\mathrm{CH}_{3}\right) \mathrm{CH}_{2} \mathrm{C}_{6} \mathrm{H}_{5}$ & $\mathrm{H}$ & $\mathrm{H}$ & 14 & see ref38 & 36 \\
\hline $7 \mathrm{i}$ & $\mathrm{OC}_{2} \mathrm{H}_{5}$ & $\mathrm{~N}\left(\mathrm{C}_{2} \mathrm{H}_{4}\right)_{2} \mathrm{NCH}_{3}$ & $\mathrm{H}$ & $\mathrm{H}$ & 15 & see $\operatorname{ref} 40$ & 25 \\
\hline $7 \mathbf{k}$ & $\mathrm{OC}_{2} \mathrm{H}_{5}$ & $\mathrm{OC}\left(\mathrm{CH}_{3}\right)_{3}$ & $\mathrm{H}$ & $\mathrm{CH}_{3}$ & 16 & Scheme 2 & 94 \\
\hline 71 & $\mathrm{OC}_{2} \mathrm{H}_{5}$ & $\mathrm{~N}\left(n-\mathrm{C}_{3} \mathrm{H}_{7}\right)_{2}$ & $\mathrm{H}$ & $\mathrm{CH}_{3}$ & 17 & see ref38 & 60 \\
\hline $7 \mathrm{~m}$ & $\mathrm{OC}\left(\mathrm{CH}_{3}\right)_{3}$ & $\mathrm{~N}\left(n-\mathrm{C}_{3} \mathrm{H}_{7}\right)_{2}$ & $\mathrm{H}$ & $\mathrm{CH}_{3}$ & 17 & see ref38 & 46 \\
\hline 70 & $\mathrm{OC}_{2} \mathrm{H}_{5}$ & $\mathrm{~N}\left(\mathrm{CH}_{3}\right) \mathrm{CH}_{2} \mathrm{C}_{6} \mathrm{H}_{5}$ & $\mathrm{H}$ & $\mathrm{CH}_{3}$ & 18 & see $\operatorname{ref} 38$ & 26 \\
\hline $7 \mathbf{p}$ & $\mathrm{OC}\left(\mathrm{CH}_{3}\right)_{3}$ & $\mathrm{~N}\left(\mathrm{CH}_{3}\right) \mathrm{CH}_{2} \mathrm{C}_{6} \mathrm{H}_{5}$ & $\mathrm{H}$ & $\mathrm{CH}_{3}$ & 18 & see ref38 & 46 \\
\hline $7 q$ & $\mathrm{OC}_{2} \mathrm{H}_{5}$ & $\mathrm{~N}\left(n-\mathrm{C}_{3} \mathrm{H}_{7}\right)_{2}$ & $\mathrm{H}$ & $\mathrm{C}_{2} \mathrm{H}_{5}$ & 19 & see $\operatorname{ref} 38$ & 27 \\
\hline $7 \mathbf{r}$ & $\mathrm{OC}\left(\mathrm{CH}_{3}\right)_{3}$ & $\mathrm{~N}\left(n-\mathrm{C}_{3} \mathrm{H}_{7}\right)_{2}$ & $\mathrm{H}$ & $\mathrm{C}_{2} \mathrm{H}_{5}$ & 19 & see ref38 & 15 \\
\hline $7 s$ & $\mathrm{OC}_{2} \mathrm{H}_{5}$ & $\mathrm{~N}\left(\mathrm{C}_{2} \mathrm{H}_{5}\right)_{2}$ & $\mathrm{H}$ & $n-\mathrm{C}_{3} \mathrm{H}_{7}$ & 20 & see $\operatorname{ref} 38$ & 21 \\
\hline $7 t$ & $\mathrm{OC}\left(\mathrm{CH}_{3}\right)_{3}$ & $\mathrm{~N}\left(\mathrm{C}_{2} \mathrm{H}_{5}\right)_{2}$ & $\mathrm{H}$ & $n-\mathrm{C}_{3} \mathrm{H}_{7}$ & 20 & see ref38 & 55 \\
\hline $7 \mathbf{u}$ & $\mathrm{OC}_{2} \mathrm{H}_{5}$ & $\mathrm{~N}\left(n-\mathrm{C}_{3} \mathrm{H}_{7}\right)_{2}$ & $\mathrm{H}$ & $n-\mathrm{C}_{3} \mathrm{H}_{7}$ & 21 & see $\operatorname{ref} 38$ & 5 \\
\hline $7 \mathbf{v}$ & $\mathrm{OC}\left(\mathrm{CH}_{3}\right)_{3}$ & $\mathrm{~N}\left(n-\mathrm{C}_{3} \mathrm{H}_{7}\right)_{2}$ & $\mathrm{H}$ & $n-\mathrm{C}_{3} \mathrm{H}_{7}$ & 21 & see $\operatorname{ref} 38$ & 4 \\
\hline $7 w$ & $\mathrm{OC}_{2} \mathrm{H}_{5}$ & $N\left(n-C_{3} H_{7}\right)_{2}$ & $\mathrm{~F}$ & $\mathrm{H}$ & 22 & Scheme 3 & 21 \\
\hline $7 \mathbf{x}$ & $\mathrm{OC}_{2} \mathrm{H}_{5}$ & $\mathrm{~N}\left(\mathrm{CH}_{3}\right) \mathrm{CH}_{2} \mathrm{C}_{6} \mathrm{H}_{5}$ & $\mathrm{~F}$ & $\mathrm{H}$ & 23 & Scheme 3 & 15 \\
\hline $7 y$ & $\mathrm{OC}_{2} \mathrm{H}_{5}$ & $\mathrm{~N}\left(\mathrm{CH}_{3}\right) \mathrm{CH}_{2} \mathrm{C}_{6} \mathrm{H}_{5}$ & $\mathrm{Br}$ & $\mathrm{H}$ & 24 & Scheme 3 & 62 \\
\hline
\end{tabular}


Scheme 3. Synthesis of the Target Imidazo[1,5-a]quinoline Derivatives Bearing Substituents in Position $7^{a}$<smiles>[Z]c1ccc2[nH]c(=O)cc(C(=O)O)c2c1</smiles><smiles>[Z]c1ccc2nc(Cl)cc(C(=O)O)c2c1</smiles>

26a,b<smiles>[Y]C(=O)c1cc(Cl)nc2ccc([Z])cc12</smiles>

22-24
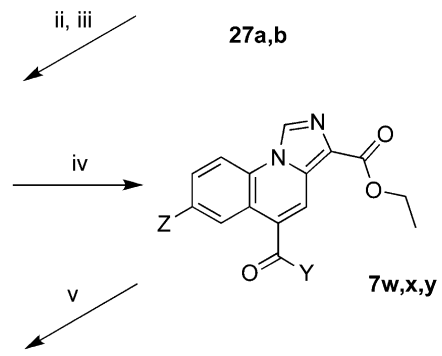

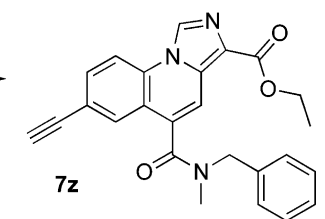

${ }^{a}$ Reagents: (i) $\mathrm{POCl}_{3}$; (ii) $\mathrm{SOCl}_{2}$; (iii) amine, $\mathrm{CH}_{2} \mathrm{Cl}_{2}$, TEA; (iv) $\mathrm{CNCH}_{2} \mathrm{COOC}_{2} \mathrm{H}_{5}$, tert-BuOK, DMF; (v) trimethylsilylacetylene, $\mathrm{Pd}\left(\mathrm{PPh}_{3}\right)_{2}(\mathrm{AcO})_{2}, \mathrm{TEA}$; (vi) $\mathrm{Bu}_{4} \mathrm{NF}$, THF. Substituents: $\mathrm{Z}=\mathrm{F}$ in 22, 23, 26a, and 27a; $\mathrm{Z}=\mathrm{Br}$ in 24, 26b, and 27b; $\mathrm{Y}=\mathrm{N}\left(n-\mathrm{C}_{3} \mathrm{H}_{7}\right)_{2}$ in $7 \mathbf{w}$ and 22; $\mathrm{Y}=\mathrm{N}\left(\mathrm{CH}_{3}\right) \mathrm{CH}_{2} \mathrm{C}_{6} \mathrm{H}_{5}$ in $7 \mathbf{x}, \mathbf{y}, 23$ and 24.

reaction with trimethylsilylacetylene to afford $7 \mathrm{aa}$, which was promptly desilylated with into $7 \mathbf{z}$.

Most of the target imidazo[1,5-a]quinoline derivatives bearing the phenyl substituents in position 5 of the tricyclic nucleus was accomplished as sketched in Scheme 4, while the preparation of compound $\mathbf{8 i}$ is described in Scheme 5.

Imidazo-annulation of suitable 2-chloro-4-phenylquinoline derivatives $28-31^{42}$ with ethyl isocyanoacetate or tert-butyl isocyanoacetate in the presence of potassium tert-butoxide gave

Scheme 4. Synthesis of the Target Imidazo[1,5-a]quinoline Derivatives Bearing the Phenyl Substituents in Position $5^{a}$

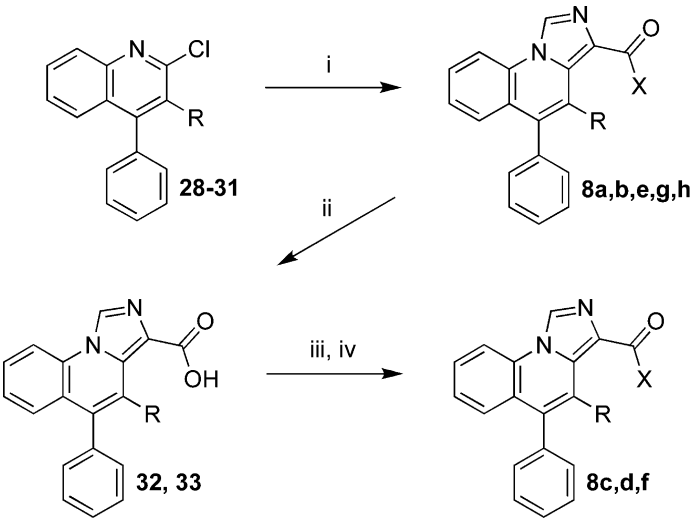

${ }^{a}$ Reagents: (i) $\mathrm{CNCH}_{2} \mathrm{COOC}_{2} \mathrm{H}_{5}$ or $\mathrm{CNCH}_{2} \mathrm{COOC}\left(\mathrm{CH}_{3}\right)_{3}$, tert$\mathrm{BuOK}, \mathrm{DMF}$; (ii) $\mathrm{HCOOH}$; (iii) 2,3,5,6-tetrafluorophenol, EDC, $\mathrm{Na}_{2} \mathrm{CO}_{3}, \mathrm{H}_{2} \mathrm{O}, \mathrm{CH}_{3} \mathrm{CN}$; (iv) $\mathrm{HN}\left(\mathrm{CH}_{3}\right)_{2}$ for $8 \mathrm{c}$ (or $\mathrm{HN}\left(\mathrm{CH}_{3}\right)-$ $\mathrm{CH}_{2} \mathrm{C}_{6} \mathrm{H}_{5}$ for 8d,f), THF. Substituents: $\mathrm{R}=\mathrm{H}$ in 8a-d, 28, and 32; $\mathrm{R}$ $=\mathrm{CH}_{3}$ in 8e,f, 29, and 33; $\mathrm{R}=\mathrm{COOC}_{2} \mathrm{H}_{5}$ in $8 \mathrm{~g}$ and 30; $\mathrm{R}=$ $\mathrm{CH}_{2} \mathrm{COOC}_{2} \mathrm{H}_{5}$ in 8h and 31; $\mathrm{X}=\mathrm{OC}_{2} \mathrm{H}_{5}$ in $\mathbf{8 a , g}, \mathbf{g}, \mathbf{h} ; \mathrm{X}=\mathrm{OC}\left(\mathrm{CH}_{3}\right)_{3}$ in $\mathbf{8 b}, \mathbf{e} ; \mathrm{X}=\mathrm{N}\left(\mathrm{CH}_{3}\right)_{2}$ in $\mathbf{8 c} ; \mathrm{X}=\mathrm{N}\left(\mathrm{CH}_{3}\right) \mathrm{CH}_{2} \mathrm{C}_{6} \mathrm{H}_{5}$ in $\mathbf{8 d}, \mathbf{f}$.
Scheme 5. Synthesis of the Imidazo[1,5-a]quinoline Derivative $8 \mathbf{i}^{a}$<smiles>CCOC(=O)c1c(Cl)nc2ccccc2c1-c1ccccc1</smiles>

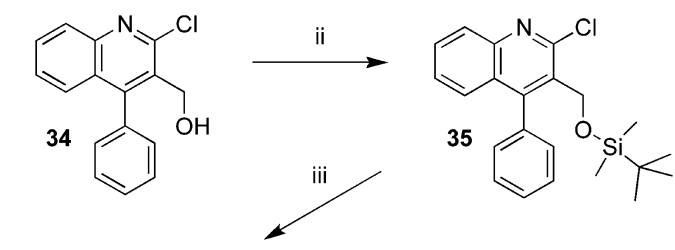<smiles>CCOC(=O)c1ncn2c1c(CO)c(-c1ccccc1)c1ccccc12</smiles>

${ }^{a}$ Reagents: (i) $\mathrm{LiAlH}_{4}$, THF; (ii) TBDMSCl, imidazole, $\mathrm{CH}_{2} \mathrm{Cl}_{2}$; (iii) $\mathrm{CNCH}_{2} \mathrm{COOC}_{2} \mathrm{H}_{5}$, tert-BuOK, DMF; (iv) $\mathrm{Bu}_{4} \mathrm{NF}$, THF.

target derivatives $\mathbf{8 a}, \mathbf{b}, \mathbf{e}, \mathbf{g}, \mathbf{h}$. The cleavage of the tert-butyl ester moiety of esters $\mathbf{8 b}, \mathbf{e}$ with formic acid gave carboxylic acid derivatives 32 and 33, which were converted via 2,3,5,6tetrafluorophenyl esters into the desired amides $\mathbf{8 c}$,d,f.

Lithium aluminum hydride reduction of ester 30 gave hydroxymethylquinoline derivative 34 , which was first protected by reaction with tert-butyldimethylsilyl chloride (TBDMSCl) and then submitted to the conditions of the imidazo-annulation with ethyl isocyanoacetate or tert-butyl isocyanoacetate to afford imidazo[1,5-a]quinoline 36 , which was promptly desilylated into target $\mathbf{8 i}$.

Finally, the imidazo-annulation was applied also to chloroderivative $37^{43}$ to obtain tetracyclic target compound 9 and to quinoxalinone derivatives 38 and $39 .{ }^{31}$ However, these latter intermediates required a more complex reaction pathway consisting of a first activation step with diethyl chlorophosphate followed by a second step of annulation with ethyl isocyanoacetate or tert-butyl isocyanoacetate in the presence of potassium tert-butoxide to obtain reference imidazo[1,5a] quinoxaline $10 a-d$ (Scheme 6). ${ }^{31}$ The structure of $10 a-c$ was confirmed by crystallographic studies (see Supporting Information).

In Vitro Binding. The affinity of the imidazo[1,5a] quinoline derivatives $7 \mathbf{a}-\mathbf{a a}, \mathbf{8 a}-\mathbf{g}$, 9 , and $\mathbf{1 0 a}-\mathbf{c}$ for $\mathrm{CBR}$ in bovine cortical membranes was measured by means of competition experiments against the radiolabeled antagonist $\left[{ }^{3} \mathrm{H}\right]$ flumazenil. The results of the binding studies are expressed as $K_{\mathrm{i}}$ values in Tables 2 and 3. The in vitro efficacy of the target compounds was tentatively estimated by measuring the GABA ratio (GR, expressed as a ratio of $K_{\mathrm{i}}$ without $\mathrm{GABA} / K_{\mathrm{i}}$ with GABA), which is considered reasonably predictive of the pharmacological profile of a CBR ligand. ${ }^{44-47}$ Usually, this value approximates 2 for full agonists and 1 for antagonists, while partial agonists show intermediate values between 1 and 2 ; finally, GABA ratio values below 1 are typical of inverse agonists. 
Scheme 6. Synthesis of Target Compounds 9 and 10a-d<smiles>CC1CCCC1</smiles>

37<smiles>[X]c1ccc2c(c1)N(C(C)=O)CC(=O)N2</smiles>

38,39

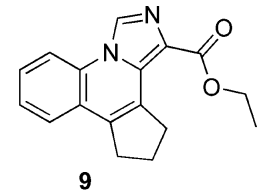

9

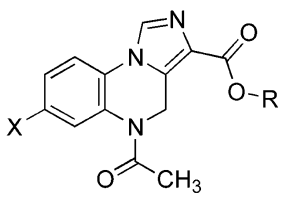

10a-d
${ }^{a}$ Reagents: (i) $\mathrm{CNCH}_{2} \mathrm{COOC}_{2} \mathrm{H}_{5}$, tert-BuOK, DMF; (ii) tert-BuOK, $\left(\mathrm{C}_{2} \mathrm{H}_{5} \mathrm{O}\right)_{2} \mathrm{POCl}$, THF; (iii) $\mathrm{CNCH}_{2} \mathrm{COOC}_{2} \mathrm{H}_{5}$ or $\mathrm{CNCH}_{2} \mathrm{COOC}$ $\left(\mathrm{CH}_{3}\right)_{3}$, tert-BuOK, THF. Substituents: $\mathrm{X}=\mathrm{H}$ in 10a,b and 38; $\mathrm{X}=\mathrm{F}$ in 10c,d and 39; $\mathrm{R}=\mathrm{C}_{2} \mathrm{H}_{5}$ in $10 \mathrm{a}, \mathbf{c} ; \mathrm{R}=\mathrm{C}\left(\mathrm{CH}_{3}\right)_{3}$ in $\mathbf{1 0 b}$,d.
Most of the compounds were found to inhibit the specific binding of radiolabeled flumazenil at the bovine CBR with $K_{\mathrm{i}}$ values within the submicromolar and the subnanomolar ranges with the full range of the intrinsic efficacy as predicted by GABA ratio values $(0.52-1.6)$.

The analysis of the structure-activity relationships confirmed the importance of the substituents in positions 4 and 5 of the imidazo[1,5-a] quinoline scaffold in modulating both the CBR affinity and the intrinsic efficacy (Figure 3 ). The most potent CBR ligands were obtained in the series of imidazo[1,5a] quinoline derivatives bearing a $N, N$-dipropylaminocarbonyl group at position 5 of the tricyclic nucleus. However, also other lipophilic substituents are tolerated in the binding site region interacting with position 5 of the imidazo[1,5-a]quinolone, namely $N, N$-dimethylaminocarbonyl, $N$-methybutylaminocarbonyl, $N$-methypropargylaminocarbonyl, $N$-methybenzylaminocarbonyl, tert-butoxycarbonyl, and phenyl groups (Figure 3).

However, the tolerance to large substituents in position 5 appeared to be conditioned by the presence of additional steric bulk in position 4 of the tricyclic scaffold (Figure 4).

Table 2. Inhibition of $\left[{ }^{3} \mathrm{H}\right]$ Flumazenil Specific Binding to CBR in Cortical Membranes and GABA Ratio Values of Compounds $7 a-a a$<smiles>[Y]C(=O)c1ncn2c1c(C([Y])=O)c([R])c1cc([Z])ccc12</smiles>

\begin{tabular}{|c|c|c|c|c|c|c|}
\hline compd & $\mathrm{X}$ & $\mathrm{Y}$ & $\mathrm{Z}$ & $\mathrm{R}$ & $K_{\mathrm{i}} \pm \mathrm{SEM}^{a}(\mathrm{nM})$ & GABA ratio ${ }^{b}$ \\
\hline $7 \mathbf{a}$ & $\mathrm{OC}_{2} \mathrm{H}_{5}$ & $\mathrm{~N}\left(\mathrm{CH}_{3}\right)_{2}$ & $\mathrm{H}$ & $\mathrm{H}$ & $8.2 \pm 2.3$ & 1.3 \\
\hline $7 b$ & $\mathrm{OC}\left(\mathrm{CH}_{3}\right)_{3}$ & $\mathrm{~N}\left(\mathrm{CH}_{3}\right)_{2}$ & $\mathrm{H}$ & $\mathrm{H}$ & $11 \pm 1.9$ & 1.6 \\
\hline $7 \mathrm{c}$ & $\mathrm{OC}_{2} \mathrm{H}_{5}$ & $\mathrm{~N}\left(\mathrm{CH}_{3}\right) n-\mathrm{C}_{4} \mathrm{H}_{9}$ & $\mathrm{H}$ & $\mathrm{H}$ & $1.9 \pm 0.7$ & 0.76 \\
\hline $7 d$ & $\mathrm{OC}\left(\mathrm{CH}_{3}\right)_{3}$ & $\mathrm{~N}\left(\mathrm{CH}_{3}\right) n-\mathrm{C}_{4} \mathrm{H}_{9}$ & $\mathrm{H}$ & $\mathrm{H}$ & $1.8 \pm 0.5$ & 0.62 \\
\hline $7 e$ & $\mathrm{OC}_{2} \mathrm{H}_{5}$ & $\mathrm{~N}\left(n-\mathrm{C}_{3} \mathrm{H}_{7}\right)_{2}$ & $\mathrm{H}$ & $\mathrm{H}$ & $0.91 \pm 0.01$ & 1.0 \\
\hline $7 f$ & $\mathrm{OC}\left(\mathrm{CH}_{3}\right)_{3}$ & $\mathrm{~N}\left(n-\mathrm{C}_{3} \mathrm{H}_{7}\right)_{2}$ & $\mathrm{H}$ & $\mathrm{H}$ & $1.2 \pm 0.5$ & 1.1 \\
\hline $7 \mathrm{~g}$ & $\mathrm{OC}_{2} \mathrm{H}_{5}$ & $\mathrm{~N}\left(\mathrm{CH}_{3}\right) \mathrm{CH}_{2} \mathrm{C}_{6} \mathrm{H}_{5}$ & $\mathrm{H}$ & $\mathrm{H}$ & $20 \pm 2.9$ & 0.52 \\
\hline $7 \mathrm{~h}$ & $\mathrm{OC}\left(\mathrm{CH}_{3}\right)_{3}$ & $\mathrm{~N}\left(\mathrm{CH}_{3}\right) \mathrm{CH}_{2} \mathrm{C}_{6} \mathrm{H}_{5}$ & $\mathrm{H}$ & $\mathrm{H}$ & $14 \pm 0.35$ & 0.98 \\
\hline $7 \mathbf{i}$ & $\mathrm{OC}_{2} \mathrm{H}_{5}$ & $\mathrm{~N}\left(\mathrm{C}_{2} \mathrm{H}_{4}\right)_{2} \mathrm{NCH}_{3}$ & $\mathrm{H}$ & $\mathrm{H}$ & $55 \pm 4.5$ & 1.0 \\
\hline $7 \mathbf{j}$ & $\mathrm{OC}_{2} \mathrm{H}_{5}$ & $\mathrm{OH}$ & $\mathrm{H}$ & $\mathrm{CH}_{3}$ & $105 \pm 26$ & 1.2 \\
\hline $7 \mathrm{k}$ & $\mathrm{OC}_{2} \mathrm{H}_{5}$ & $\mathrm{OC}\left(\mathrm{CH}_{3}\right)_{3}$ & $\mathrm{H}$ & $\mathrm{CH}_{3}$ & $1.0 \pm 0.37$ & 1.4 \\
\hline 71 & $\mathrm{OC}_{2} \mathrm{H}_{5}$ & $\mathrm{~N}\left(n-\mathrm{C}_{3} \mathrm{H}_{7}\right)_{2}$ & $\mathrm{H}$ & $\mathrm{CH}_{3}$ & $1.5 \pm 0.08$ & 1.3 \\
\hline $7 \mathrm{~m}$ & $\mathrm{OC}\left(\mathrm{CH}_{3}\right)_{3}$ & $\mathrm{~N}\left(n-\mathrm{C}_{3} \mathrm{H}_{7}\right)_{2}$ & $\mathrm{H}$ & $\mathrm{CH}_{3}$ & $1.0 \pm 0.03$ & 1.1 \\
\hline $7 \mathbf{n}$ & $\mathrm{OC}_{2} \mathrm{H}_{5}$ & $\mathrm{~N}\left(\mathrm{CH}_{3}\right) \mathrm{CH}_{2} \mathrm{CCH}$ & $\mathrm{H}$ & $\mathrm{CH}_{3}$ & $1.2 \pm 0.02$ & 1.0 \\
\hline 70 & $\mathrm{OC}_{2} \mathrm{H}_{5}$ & $\mathrm{~N}\left(\mathrm{CH}_{3}\right) \mathrm{CH}_{2} \mathrm{C}_{6} \mathrm{H}_{5}$ & $\mathrm{H}$ & $\mathrm{CH}_{3}$ & $6.5 \pm 0.4$ & 1.1 \\
\hline $7 p$ & $\mathrm{OC}\left(\mathrm{CH}_{3}\right)_{3}$ & $\mathrm{~N}\left(\mathrm{CH}_{3}\right) \mathrm{CH}_{2} \mathrm{C}_{6} \mathrm{H}_{5}$ & $\mathrm{H}$ & $\mathrm{CH}_{3}$ & $2.6 \pm 0.1$ & 1.0 \\
\hline $7 q$ & $\mathrm{OC}_{2} \mathrm{H}_{5}$ & $\mathrm{~N}\left(n-\mathrm{C}_{3} \mathrm{H}_{7}\right)_{2}$ & $\mathrm{H}$ & $\mathrm{C}_{2} \mathrm{H}_{5}$ & $2.5 \pm 0.3$ & 1.5 \\
\hline $7 \mathbf{r}$ & $\mathrm{OC}\left(\mathrm{CH}_{3}\right)_{3}$ & $\mathrm{~N}\left(n-\mathrm{C}_{3} \mathrm{H}_{7}\right)_{2}$ & $\mathrm{H}$ & $\mathrm{C}_{2} \mathrm{H}_{5}$ & $5.6 \pm 0.4$ & 1.4 \\
\hline $7 \mathrm{~s}$ & $\mathrm{OC}_{2} \mathrm{H}_{5}$ & $\mathrm{~N}\left(\mathrm{C}_{2} \mathrm{H}_{5}\right)_{2}$ & $\mathrm{H}$ & $n-\mathrm{C}_{3} \mathrm{H}_{7}$ & $169 \pm 14$ & 0.9 \\
\hline $7 t$ & $\mathrm{OC}\left(\mathrm{CH}_{3}\right)_{3}$ & $\mathrm{~N}\left(\mathrm{C}_{2} \mathrm{H}_{5}\right)_{2}$ & $\mathrm{H}$ & $n-\mathrm{C}_{3} \mathrm{H}_{7}$ & $2870 \pm 250$ & 1.1 \\
\hline $7 \mathbf{u}$ & $\mathrm{OC}_{2} \mathrm{H}_{5}$ & $\mathrm{~N}\left(n-\mathrm{C}_{3} \mathrm{H}_{7}\right)_{2}$ & $\mathrm{H}$ & $n-\mathrm{C}_{3} \mathrm{H}_{7}$ & $34 \pm 4.5$ & 1.1 \\
\hline $7 \mathbf{v}$ & $\mathrm{OC}\left(\mathrm{CH}_{3}\right)_{3}$ & $\mathrm{~N}\left(n-\mathrm{C}_{3} \mathrm{H}_{7}\right)_{2}$ & $\mathrm{H}$ & $n-\mathrm{C}_{3} \mathrm{H}_{7}$ & $1437 \pm 120$ & 1.0 \\
\hline $7 w$ & $\mathrm{OC}_{2} \mathrm{H}_{5}$ & $\mathrm{~N}\left(n-\mathrm{C}_{3} \mathrm{H}_{7}\right)_{2}$ & $\mathrm{~F}$ & $\mathrm{H}$ & $0.44 \pm 0.2$ & 0.8 \\
\hline $7 \mathbf{x}$ & $\mathrm{OC}_{2} \mathrm{H}_{5}$ & $\mathrm{~N}\left(\mathrm{CH}_{3}\right) \mathrm{CH}_{2} \mathrm{C}_{6} \mathrm{H}_{5}$ & $\mathrm{~F}$ & $\mathrm{H}$ & $5.7 \pm 2.6$ & 0.8 \\
\hline $7 y$ & $\mathrm{OC}_{2} \mathrm{H}_{5}$ & $\mathrm{~N}\left(\mathrm{CH}_{3}\right) \mathrm{CH}_{2} \mathrm{C}_{6} \mathrm{H}_{5}$ & $\mathrm{Br}$ & $\mathrm{H}$ & $24 \pm 1.7^{c}$ & $0.90^{c}$ \\
\hline $7 \mathrm{z}$ & $\mathrm{OC}_{2} \mathrm{H}_{5}$ & $\mathrm{~N}\left(\mathrm{CH}_{3}\right) \mathrm{CH}_{2} \mathrm{C}_{6} \mathrm{H}_{5}$ & $\mathrm{CCH}$ & $\mathrm{H}$ & $161 \pm 24^{c}$ & $0.95^{c}$ \\
\hline $7 \mathbf{a a}$ & $\mathrm{OC}_{2} \mathrm{H}_{5}$ & $\mathrm{~N}\left(\mathrm{CH}_{3}\right) \mathrm{CH}_{2} \mathrm{C}_{6} \mathrm{H}_{5}$ & $\mathrm{CCSi}\left(\mathrm{CH}_{3}\right)_{3}$ & $\mathrm{H}$ & $510 \pm 48^{c}$ & $0.99^{c}$ \\
\hline flunitrazepam & & & & & $5.2 \pm 0.2$ & 1.68 \\
\hline flumazenil & & & & & $1.9 \pm 0.09$ & 1.03 \\
\hline
\end{tabular}

${ }^{a} K_{\mathrm{i}}$ values are means $\pm \mathrm{SEM}$ of three independent determinations in bovine cortical membranes. ${ }^{b} \mathrm{GABA}$ ratio $=\left(K_{\mathrm{i}}\right.$ without GABA $/ K_{\mathrm{i}}$ with $50 \mu \mathrm{M}$ GABA). ${ }^{c}$ The values were obtained in rat cortical membranes. 
Table 3. Inhibition of $\left[{ }^{3} \mathrm{H}\right]$ Flumazenil Specific Binding to CBR in Cortical Membranes and GABA Ratio Values of Compounds $8 a-i, 9$, and $10 a-d$

\begin{tabular}{|c|c|c|c|c|c|c|}
\hline \multirow[b]{2}{*}{ compd } & \multirow[b]{2}{*}{$\mathrm{X}$} & \multirow[b]{2}{*}{$\mathrm{R}$} & \multicolumn{2}{|c|}{ bovine } & \multicolumn{2}{|c|}{ human } \\
\hline & & & $K_{\mathrm{i}} \pm \mathrm{SEM}^{a}(\mathrm{nM})$ & $\mathrm{GABA}$ ratio $^{b}$ & $K_{\mathrm{i}} \pm \operatorname{SEM}^{a}(\mathrm{nM})$ & GABA ratio $^{b}$ \\
\hline $8 \mathbf{a}$ & $\mathrm{OC}_{2} \mathrm{H}_{5}$ & $\mathrm{H}$ & $42 \pm 9.6$ & 0.9 & & \\
\hline $8 b$ & $\mathrm{OC}\left(\mathrm{CH}_{3}\right)_{3}$ & $\mathrm{H}$ & $55 \pm 32$ & 0.8 & & \\
\hline $8 \mathrm{c}$ & $\mathrm{N}\left(\mathrm{CH}_{3}\right)_{2}$ & $\mathrm{H}$ & $3515 \pm 360$ & 1.44 & & \\
\hline $8 d$ & $\mathrm{~N}\left(\mathrm{CH}_{3}\right) \mathrm{CH}_{2} \mathrm{C}_{6} \mathrm{H}_{5}$ & $\mathrm{H}$ & $449 \pm 10$ & 0.92 & & \\
\hline $8 \mathrm{e}$ & $\mathrm{OC}\left(\mathrm{CH}_{3}\right)_{3}$ & $\mathrm{CH}_{3}$ & $10 \pm 2.8$ & 1.0 & & \\
\hline $8 f$ & $\mathrm{~N}\left(\mathrm{CH}_{3}\right) \mathrm{CH}_{2} \mathrm{C}_{6} \mathrm{H}_{5}$ & $\mathrm{CH}_{3}$ & $>1000^{c}$ & & & \\
\hline $8 g$ & $\mathrm{OC}_{2} \mathrm{H}_{5}$ & $\mathrm{COOC}_{2} \mathrm{H}_{5}$ & $2193 \pm 633$ & 0.66 & & \\
\hline $8 \mathrm{~h}$ & $\mathrm{OC}_{2} \mathrm{H}_{5}$ & $\mathrm{CH}_{2} \mathrm{COOC}_{2} \mathrm{H}_{5}$ & $3.8 \pm 2.1$ & 0.72 & & \\
\hline $8 \mathrm{i}$ & $\mathrm{OC}_{2} \mathrm{H}_{5}$ & $\mathrm{CH}_{2} \mathrm{OH}$ & $1.8 \pm 0.1$ & 1.18 & $2.0 \pm 0.2$ & \\
\hline 9 & & & $18 \pm 3.5$ & 1.3 & & \\
\hline $10 a$ & $\mathrm{H}$ & $\mathrm{C}_{2} \mathrm{H}_{5}$ & $25 \pm 9.6$ & 0.90 & $33 \pm 4.2$ & \\
\hline $10 \mathbf{b}^{d}$ & $\mathrm{H}$ & $\mathrm{C}\left(\mathrm{CH}_{3}\right)_{3}$ & $7.3 \pm 1.5$ & 0.98 & $7.7 \pm 1.3$ & 1.04 \\
\hline $10 \mathrm{c}$ & $\mathrm{F}$ & $\mathrm{C}_{2} \mathrm{H}_{5}$ & $2.2 \pm 0.42$ & 0.75 & $2.7 \pm 0.3$ & 0.95 \\
\hline $10 \mathrm{~d}$ & $\mathrm{~F}$ & $\mathrm{C}\left(\mathrm{CH}_{3}\right)_{3}$ & $1.0 \pm 0.46$ & 1.0 & $2.0 \pm 0.3$ & 1.0 \\
\hline flunitrazepam & & & $5.2 \pm 0.2$ & 1.68 & $6.4 \pm 0.5$ & 1.61 \\
\hline flumazenil & & & $1.9 \pm 0.09$ & 1.03 & $2.0 \pm 0.08$ & 1.02 \\
\hline
\end{tabular}

${ }^{a} K_{\mathrm{i}}$ values are means $\pm \mathrm{SEM}$ of three independent determinations. ${ }^{b} \mathrm{GABA}$ ratio $=\left(K_{\mathrm{i}}\right.$ without $\mathrm{GABA} / \mathrm{K}_{\mathrm{i}}$ with $\left.50 \mu \mathrm{M} \mathrm{GABA}\right) .{ }^{c} 19 \%$ displacement at $1000 \mathrm{nM} .{ }^{d}$ See ref 31.
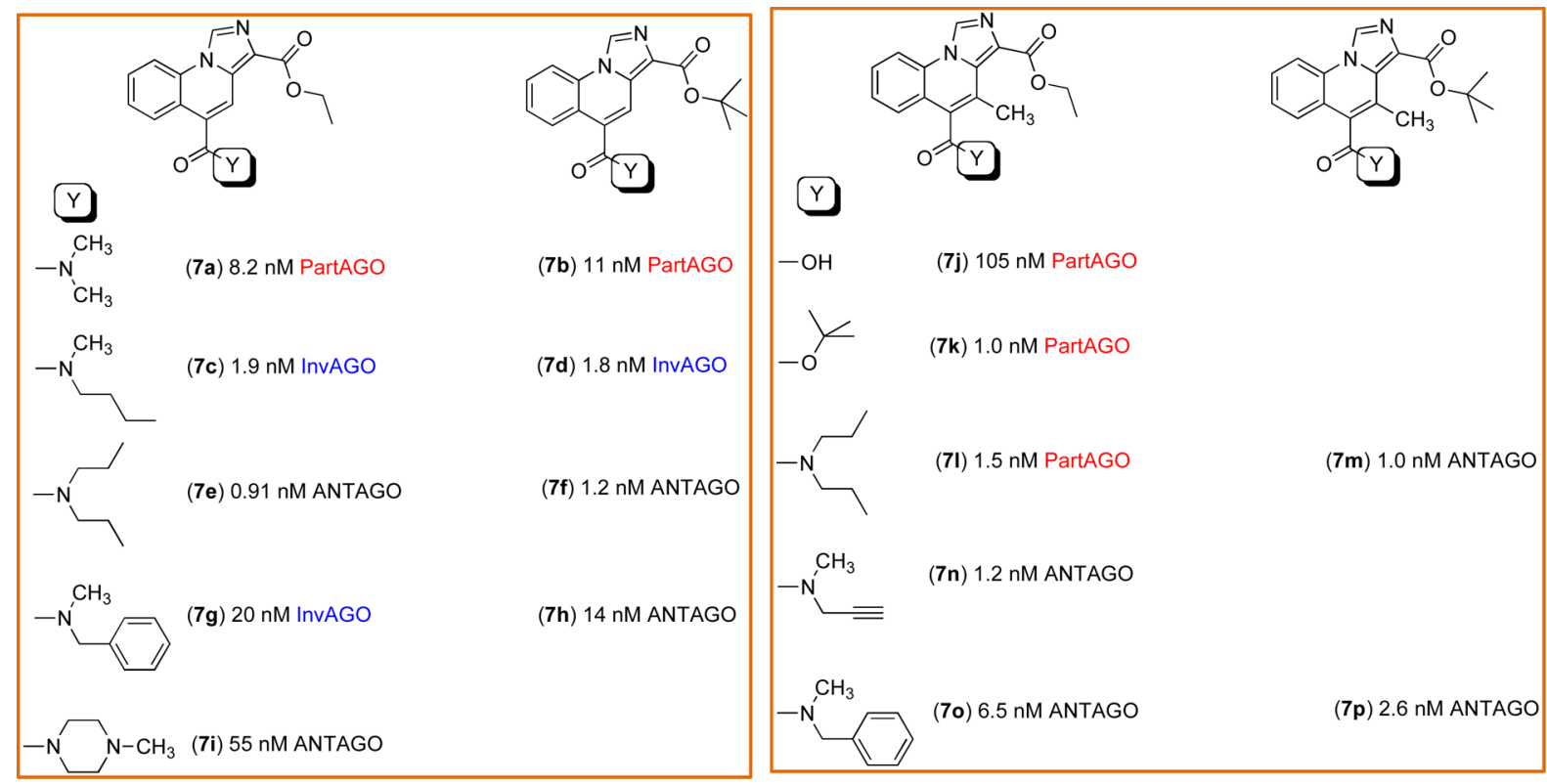

Figure 3. SAR in imidazo[1,5-a] quinoline derivatives $7 \mathbf{a}-\mathbf{i}$ and $7 \mathbf{j}-\mathbf{p}$. Effects of the lipophilic substituents in position 5 .

In fact, in the dipropylamido subseries (Figure 4), the increase of the alkyl side chain length led to a stepwise decrease in CBR affinity with a rapid acceleration in propyl derivatives $7 \mathbf{u}, \mathbf{v}$. This result can be rationalized in terms of interactions between the ester group and the alkyl moiety in position 4 but also with by assuming that the lipophilic pocket can be saturated as previously observed in $5-\mathrm{HT}_{3}$ receptors. ${ }^{38}$

On the other hand, in the imidazo[1,5-a] quinoline subseries bearing a phenyl group in position 5 (Figure 4), the effects of the substituents in position 4 were highly variable and appeared to depend on the stereoelectronic features of the substituent itself.

In general, small substituents such as $\mathrm{H}, \mathrm{CH}_{3}$, and $\mathrm{CH}_{2} \mathrm{OH}$ are tolerated better than the bulkier carbethoxy group of compound $8 \mathrm{~g}$, but the spacing of the ester group by a methylene bridge as in $\mathbf{8 h}$ restored nanomolar CBR affinity, suggesting the involvement of specific interactions. 


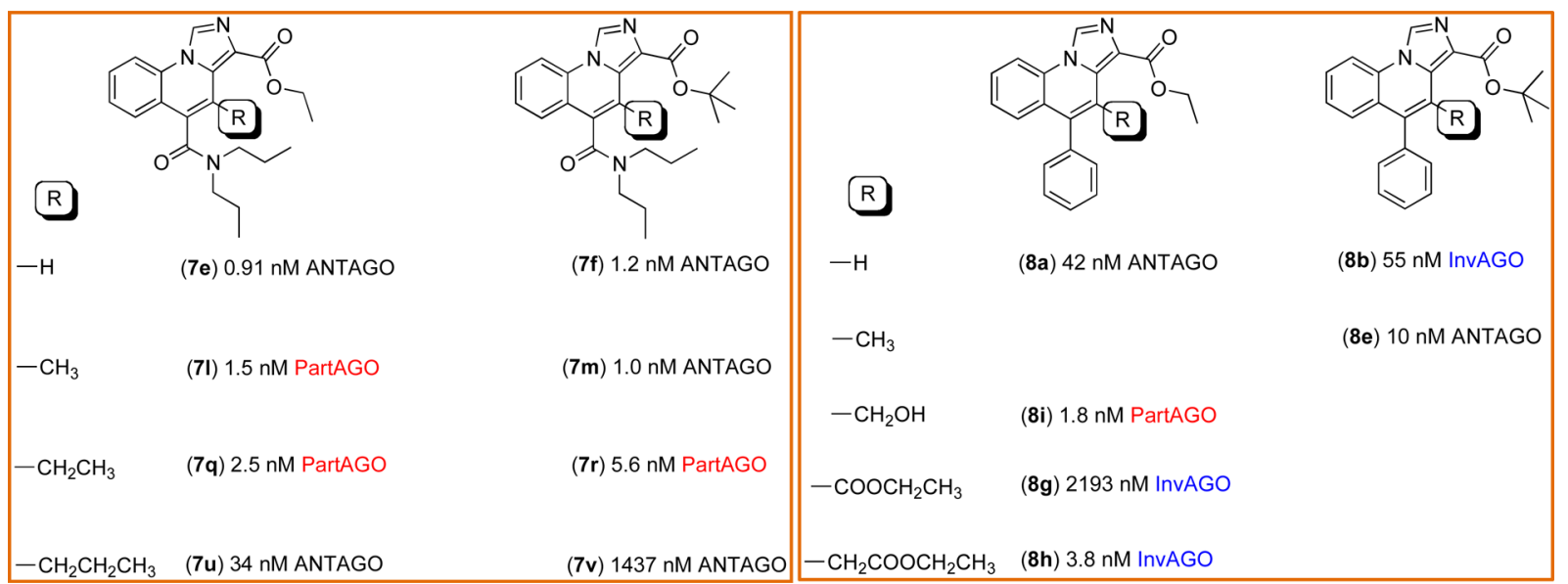

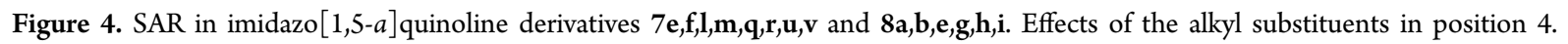

As already observed in related CBR ligands, the presence of small atoms such as $\mathrm{H}$ or $\mathrm{F}$ in position 7 is required for nanomolar CBR affinity, whereas the presence of the bulkier bromine atom produces a significant drop in CBR affinity that became dramatic (i.e., almost 2 orders of magnitude) when alkyne substituents are present in this position as in compounds $7 \mathbf{z}$-aa (Figure 5).
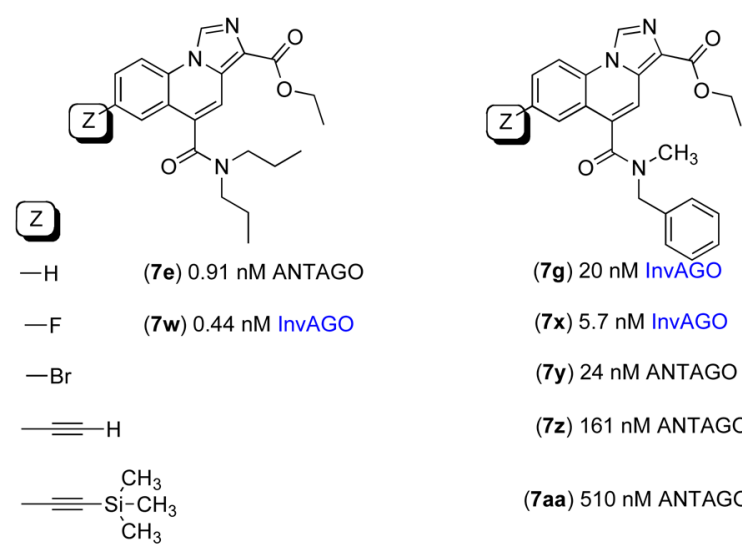

(7x) 5.7 nM InvAGO

(7y) 24 nM ANTAGO

(7z) 161 nM ANTAGO

(7aa) 510 nM ANTAGO

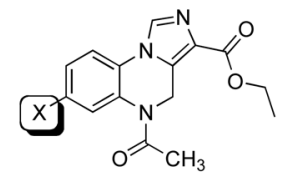<smiles>[Y4]C1CCCC1</smiles>

X

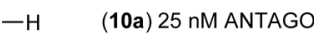

-F (10c) $2.2 \mathrm{nM}$ InvAGO

(10b) $7.3 \mathrm{nM}$ ANTAGO

(10d) 1.0 nM ANTAGO

Figure 5. SAR in imidazo $[1,5-a]$ quinolines $7 \mathbf{e}, \mathbf{g}, \mathbf{w}, \mathbf{x}, \mathbf{y}, \mathbf{z}, \mathbf{a a}$ and reference imidazo[1,5-a] quinoxalines $10 a-d$. Effects of the substituents in position 7 .

It is noteworthy that the beneficial effect of the fluorine substituent was less evident in imidazo[1,5-a]quinoline derivatives $7 \mathbf{w}, \mathbf{x}$ than in imidazo[1,5-a]quinoxaline derivatives 10c,d. However, by virtue of its subnanomolar CBR affinity $\left(K_{\mathrm{i}}\right.$ $=0.44 \mathrm{nM}$ ), fluoroderivative $7 \mathbf{w}$ resulted more potent than the corresponding imidazo[1,5-a] quinoxaline derivative $10 \mathrm{c}$ and is the most potent ligand among the imidazo[1,5- $a]$ quinoline derivatives described so far.
Finally, the replacement of ester groups in position 3 of imidazo[1,5-a] quinoline derivatives $\mathbf{8 a}, \mathbf{b}, \mathbf{e}$ with the amide ones of $\mathbf{8 c , d , f}$ (Figure 6) was deleterious from the point of view of the interaction with CBR binding site producing low affinity ligands.
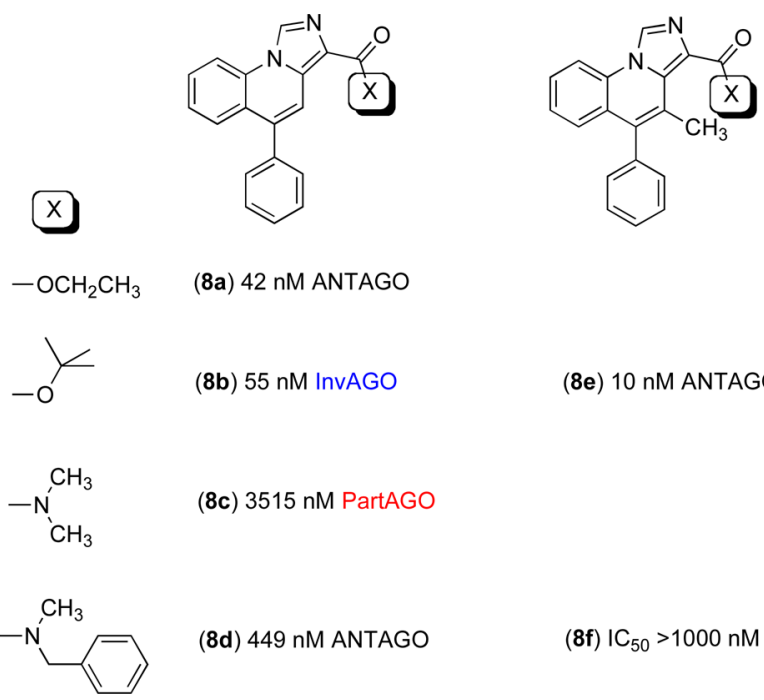

(8a) 42 nM ANTAGO

(8b) $55 \mathrm{nM}$ InvAGO

(8e) 10 nM ANTAGO

(8c) $3515 \mathrm{nM}$ PartAGO

(8d) 449 nM ANTAGO

(8f) $I C_{50}>1000 \mathrm{nM}$

Figure 6. SAR in imidazo[1,5-a]quinolines $8 \mathbf{a}-\mathbf{f}$. Effects of the substituents in position 3 .

In Vitro Efficacy in ${ }^{36} \mathrm{Cl}^{-}$Uptake Assay in Rat Cerebrocortical Synaptoneurosomes. The comparison of the GABA ratio values showed a rather complex pattern in the structure-activity relationships of imidazo[1,5-a]quinoline derivatives $7 \mathbf{a}-\mathbf{a a}, \mathbf{8 a}-\mathbf{g}, \mathbf{9}$, and $\mathbf{1 0 a}-\mathbf{c}$. In general, the agonist-like properties appeared to be linked to the presence of relatively small substituents (i.e., 7a,b), whereas the presence of large lipophilic substituents appeared to be associated with antagonist-like features. However, ligands showing apparently different intrinsic efficacy were present in the same subseries without evidencing a clear trend. This could be due both to the complexity of the interaction and to possible experimental errors.

Thus, the predictive capability of GABA ratio values was evaluated in the limited set of reference imidazo[1,5- $a$ quinoxaline derivatives $\mathbf{1 0 b}-\mathbf{d}$ by means of a more direct measure of in vitro efficacy consisting in ${ }^{36} \mathrm{Cl}^{-}$uptake assay in 
rat cerebrocortical synaptoneurosomes. ${ }^{48,49}$ The synaptic chloride conductance effected by GABA activating the $\mathrm{GABA}_{\mathrm{A}}$ receptor complex is modulated by ligands acting at the CBR. In particular, agonists increase the current, antagonists are ineffective, and inverse agonists decrease the ion flow. The results shown in Figure 7 suggested that reference $10 \mathrm{~b}$ behaved as a CBR antagonist in agreement with its GABA ratio values $(0.98-1.04)$ and with the data described in the literature. $^{31}$

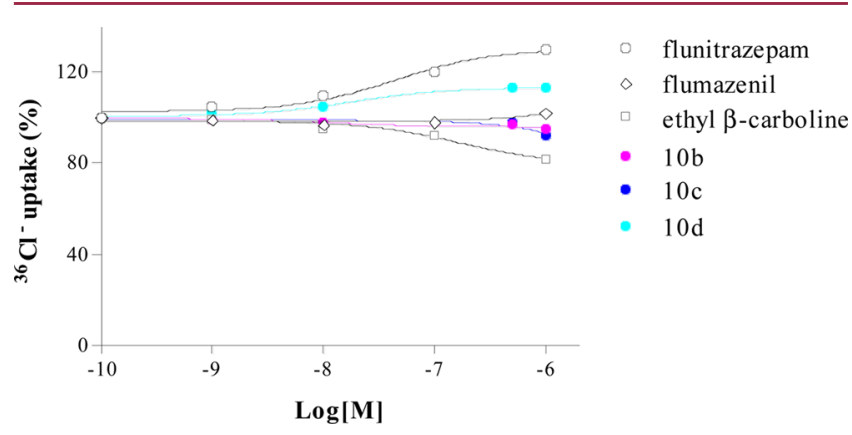

Figure $7 .{ }^{36} \mathrm{Cl}^{-}$uptake measured in rat cerebrocortical synaptoneurosomes for compounds 10b (magenta), 10c (blue), 10d (cyan), flunitrazepam (empty circles), flumazenil (empty diamonds), and ethyl $\beta$-carboline (empty squares).

Compound 10d (GABA ratio $=1.0)$ showed a very slight increase of ${ }^{36} \mathrm{Cl}^{-}$influx, behaving as a partial agonist characterized by a very low intrinsic efficacy. On the other hand, an even slight decrease in the ion flow was observed with compound 10c (GABA ratio in bovine $\mathrm{CBR}=0.75$, in human $\mathrm{CBR}=0.95$ ), which could be therefore classified either as a partial inverse agonist showing a very low intrinsic efficacy or as an antagonist. No massive ${ }^{36} \mathrm{Cl}^{-}$influx was promoted by these reference compounds in agreement with their antagonist-like or partial inverse agonist properties as predicted by GABA ratio values. On the whole, these apparent discrepancies emphasized the importance of a suitable biological characterization of the newly synthesized CBR ligands in order to appreciate their pharmacological profile.

In Vitro Efficacy in Excytotoxic-Mediate Injury. The disruptions in GABA signaling is involved in many acute and chronic neurodegenerative disorders such as temporal lobe epilepsy, Parkinson's disease (PD), Huntington's disease (HD), and brain ischemia. The GABAergic system is indeed indispensable to keep the balance between the excitation and the inhibition required for normal neuronal function. An imbalance between these systems contribute to excitotoxicity and neuronal cell death. Consequently, modulation of the GABAergic system can successfully reverse excitotoxic-induced injury in disease models, suggesting that therapeutic strategies targeting the GABAergic system could be effective in treating neurodegenerative disorders. ${ }^{50-52}$ Positive modulators of the $\mathrm{GABA}_{\mathrm{A}}$ receptors, such as diazepam and the partial agonist imidazo $[1,5-a]$ quinoline derivative 5 , have proven to show neuroprotective properties in different models of excytotoxicmediated injury. ${ }^{53-57}$ Therefore, imidazo[1,5-a]quinoline derivatives $7 \mathbf{l}, \mathbf{q}, \mathbf{r}$, and $\mathbf{8} \mathbf{i}$ were selected on the basis of their $K_{\mathrm{i}}$ and GABA ratio values (i.e., nanomolar CBR affinity and partial agonist profile) and tested for their potential neuroprotective
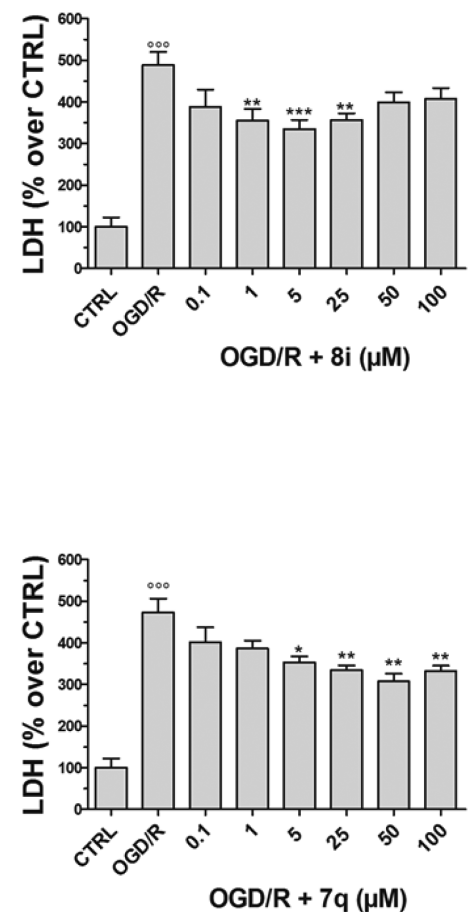
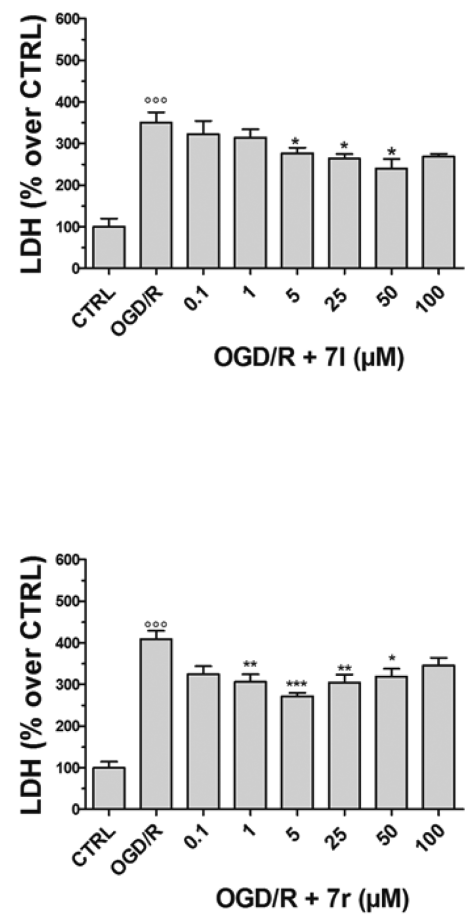

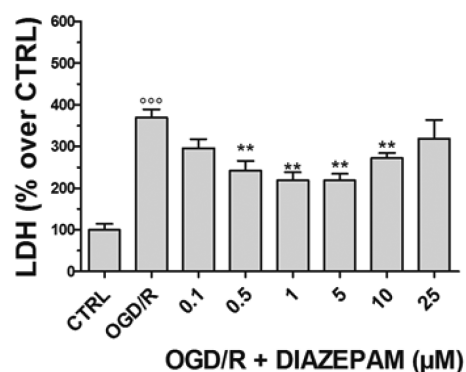

OGD/R + DIAZEPAM $(\mu M)$

Figure 8. Effects of $7 \mathbf{l}, \mathbf{q}, \mathbf{r}, \mathbf{8 i}$, and diazepam on oxygen-glucose deprivation and reoxygenation (OGD/R)-induced release of LDH of rat brain cortical slices. Slices were incubated in artificial cerebrospinal fluid (ACSF) for $120 \mathrm{~min}$ (control conditions, CTRL) or subjected for $30 \mathrm{~min}$ to oxygen/glucose deprivation followed by $90 \mathrm{~min}$ incubation in normally oxygenated ACSF (reperfusion). Increasing concentrations of the compounds $(0.1-100 \mu \mathrm{M})$ were added to ACSF during the 90 min reperfusion phase. Data are means \pm SEM of at least four different experiments. ${ }^{\circ 00} P<0.01$ vs CTRL; $* P<0.05, * * P<0.01, * * * P<0.001$ vs OGD/R (ANOVA followed by Dunnet post-test). 
activity. Rat cortical brain slices were subjected to excitotoxicmediated damage (i.e., oxygen-glucose deprivation and reoxygenation, $\mathrm{OGD} / \mathrm{R}$ ) and neuronal injury/neuroprotection was assessed by measuring the release of lactate dehydrogenase (LDH). All drug molecules were added during reperfusion and their effects were compared to those exerted by diazepam. The results demonstrated that diazepam exerted neuroprotective effects according to a "U-shaped", hormetic-like, concentration-response curve, with an efficacy window of $0.5-10 \mu \mathrm{M}$ (Figure 8). In this range, the maximum recovery in $\mathrm{LDH}$ release was $55.9 \%$, which was observed at both 1 and $5 \mu \mathrm{M}$ concentrations (Table 4).

Table 4. Effects of 7l,q,r, 8i, and Diazepam on OxygenGlucose Deprivation and Reoxygenation (OGD/R)-Induced Release of LDH of Rat Brain Cortical Slices ${ }^{a}$

\begin{tabular}{|c|c|c|c|}
\hline compd & efficacy window ${ }^{b}(\mu \mathrm{M})$ & $\mathrm{EC}^{c}(\mu \mathrm{M})$ & recovery $^{d}(\%)$ \\
\hline 71 & $5-50$ & 50 & $44.0 \pm 8.5^{*}$ \\
\hline $7 \mathbf{q}$ & $5-100$ & 50 & $44.3 \pm 4.8^{* * *}$ \\
\hline $7 \mathbf{r}$ & $1-50$ & 5 & $44.4 \pm 2.4^{* * *}$ \\
\hline $8 \mathrm{i}$ & $1-25$ & 5 & $39.5 \pm 5.6^{* * *}$ \\
\hline \multirow[t]{2}{*}{1} & $0.5-10$ & 1 & $55.9 \pm 7.1^{* * *}$ \\
\hline & & 5 & $55.9 \pm 5.9^{* * *}$ \\
\hline
\end{tabular}

${ }^{a}$ Rat cortical brain slices were subjected to oxygen-glucose deprivation and reoxygenation and neuronal injury/neuroprotection was assessed by measuring the release of lactate dehydrogenase (LDH). All drugs were added during reperfusion. ${ }^{b}$ The efficacy windows represent the range of concentrations at which a significant reduction of OGD and reperfusion-induced LDH release was observed. ${ }^{c} \mathrm{EC}$ (effective concentration) is the $\mu \mathrm{M}$ concentration at which the highest reduction was observed. ${ }^{d}$ The recovery value represents the $\%$ of reversion exerted at EC concentration; $100 \%$ was taken as the return to basal values (CTRL). Recovery data are reported as mean \pm SEM and the comparison between values was performed by using ANOVA followed by Dunnet post-hoc test. $P<0.05, * * * P<0.001$ vs OGD/R.

The hormetic effect of diazepam was already observed ${ }^{54}$ and might be explained by considering that elevated diazepam levels at the synaptic cleft might cause an excessive activation of $\mathrm{GABA}_{\mathrm{A}}$ receptors, which increases the overload of $\mathrm{Cl}^{-}$and causes $\mathrm{GABA}_{\mathrm{A}}$ desensitization, thus resulting in depolarization and neuron damages. ${ }^{58,59}$ In the same way, imidazo[1,5a] quinoline derivatives $7 \mathbf{l}, \mathbf{q}, \mathbf{r}$, and $\mathbf{8 i}$ showed neuroprotective properties. All the compounds, in fact, reduced OGD/Rinduced LDH release in a hormetic-like fashion although with different efficacy windows. In particular, $8 \mathbf{i}$ and $7 \mathbf{r}$ were the most interesting compounds (Figure 8 ) because they exerted their effects in a wider concentration range than diazepam (i.e., $1-25 \mu \mathrm{M} 8 \mathbf{i}$ or $1-50 \mu \mathrm{M} 7 \mathbf{r}$ ), but the maximum recovery in $\mathrm{LDH}$ release was lower $(39.5 \%$ and $44.4 \%$, respectively, at 5 $\mu \mathrm{M}$, see Table 4). Also, $7 \mathbf{l}, \mathbf{q}$ reverted the release of the endocellular enzyme caused by the ischemia-like conditions but the maximum effect was observed at $50 \mu \mathrm{M}$ concentration and the recovery was $44 \%$. Taken together, these results suggests that $7 \mathbf{l}, \mathbf{q}, \mathbf{r}$ and $8 \mathbf{i}$ could behave as partial agonists at $\mathrm{GABA}_{\mathrm{A}}$ receptors in the present experimental model because they exhibited lower efficacy than the positive $\mathrm{GABA}_{\mathrm{A}}$ modulator diazepam.

In Vivo Efficacy. The newly synthesized compounds $7 \mathbf{a}, \mathbf{c}, \mathbf{d}, \mathbf{l}, \mathbf{m}, \mathbf{p}, \mathbf{q}, \mathbf{r}, \mathbf{w}$ were evaluated in mice as modulators of central nervous system functionalities after per os administration. In particular, four pharmacological actions were taken into consideration. The light-dark box test was used to ascertain the potential anxiolytic effect, while the rota-rod test measured the myorelaxant effect, the hole-board test was performed to assess the effects on mouse spontaneous motility and explorative activity, and the passive avoidance test was finally used to evaluate the mouse learning and memory impairment.

The anxiolytic effect of the molecules is shown in Figure 9. The light-dark box test is based on the innate aversion of

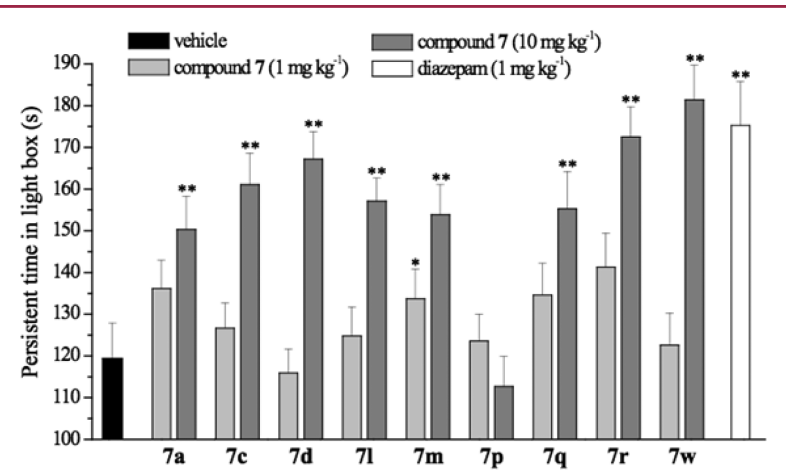

Figure 9. Light-dark box test. Anxiolytic activity. The new compounds were administered per os, and diazepam $\left(1 \mathrm{mg} \mathrm{kg}^{-1}\right)$ was administered subcutaneously. All treatments were performed 30 min before the test. Each value represents the mean \pm SEM of at least 10 mice. ${ }^{*} P<0.01$ in comparison to vehicle-treated mice.

rodents to the brightly lit and open areas and on the spontaneous novelty-induced exploratory behavior, allowing the evaluation of potential anxiolytic compounds. All compounds, with the exception of $7 p$, increased the time spent in the light box after dosing at $10 \mathrm{mg} \mathrm{kg}^{-1}$. Compounds $7 \mathrm{~d}(167.2 \pm 6.5 \mathrm{~s}), 7 \mathrm{r}(172.5 \pm 7.2 \mathrm{~s})$, and $7 \mathbf{w}(181.4 \pm 8.3 \mathrm{~s})$ were the most effective showing a comparable effect with diazepam (1 $\mathrm{mg} \mathrm{kg}^{-1}$ subcutaneously) (Figure 9). Compound 7d presented a dose-dependent anxiolytic effect, which was significant starting from $3 \mathrm{mg} \mathrm{kg}^{-1}(144.8 \pm 6.3 \mathrm{~s}$; data not shown). A similar potency was showed by compound 7l, which was active starting from $3 \mathrm{mg} \mathrm{kg}{ }^{-1}(153.4 \pm 6.1 \mathrm{~s}$; data not shown) peaking at $10 \mathrm{mg} \mathrm{kg}^{-1}$ (Figure 9). Compound $7 \mathbf{m}$ was the most potent because it was effective at $1 \mathrm{mg} \mathrm{kg}^{-1}$ (Figure 9 ), whereas $7 \mathbf{p}$ was ineffective when administered at 1 and 10 $\mathrm{mg} \mathrm{kg}^{-1}$ (Figure 9), but by increasing the dose to $30 \mathrm{mg} \mathrm{kg}^{-1}$ the time was enhanced up to $139.2 \pm 5.1 \mathrm{~s}$ (data not shown).

To validate the behavioral measurements, possible neurological or muscular side effects of the tested compounds were excluded by the hole-board and the rota-rod tests. All the compounds $\left(10 \mathrm{mg} \mathrm{kg}^{-1}\right)$ did not alter the neurological and muscular abilities of the mice as evaluated by the hole-board test $30 \mathrm{~min}$ after treatment. The number of movements (motor activity) and the number of inspections (exploratory activity) were comparable to vehicle-treated animals (Figure 10).

Similarly, no negative effects on motor coordination emerged in the rota-rod test (Figure 11). The treated animals showed a progressive ability to maintain the balance on a rotating rod.

The nootropic effects were assessed in the passive avoidance test measuring the prevention of scopolamine-induced amnesia. The muscarinic antagonist drastically reduced the time spent in the light box of the apparatus during the retention session ( 44.8 $\pm 8.1 \mathrm{~s}$ vs $101.4 \pm 7.0 \mathrm{~s}$ of vehicle-treated animals; second experimental day) highlighting a lack of memory of the punishment received in the dark box (Figure 12). Compounds $\mathbf{7 c , d}, \mathbf{l}, \mathbf{m}, \mathbf{p}, \mathbf{q}, \mathbf{r}, \mathbf{w}\left(10 \mathrm{mg} \mathrm{kg}^{-1}\right)$ were able to significantly prevent 


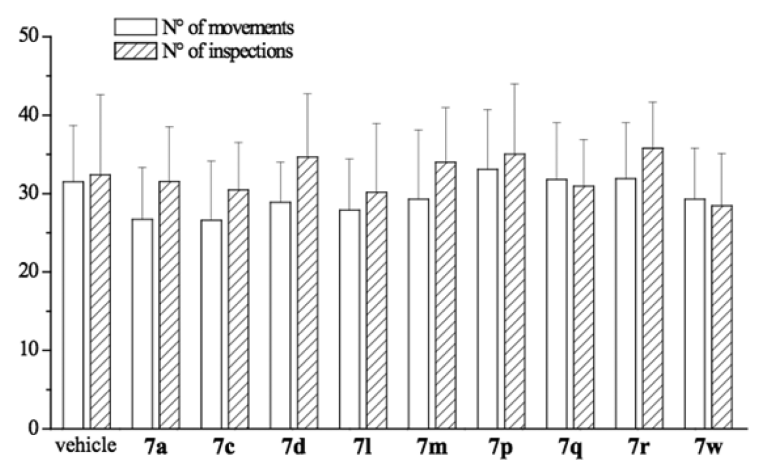

Figure 10. Hole-board test. Effects on neurological and muscular abilities. All compounds were administered per os $30 \mathrm{~min}$ before the test. Each value represents the mean \pm SEM of at least 10 mice.

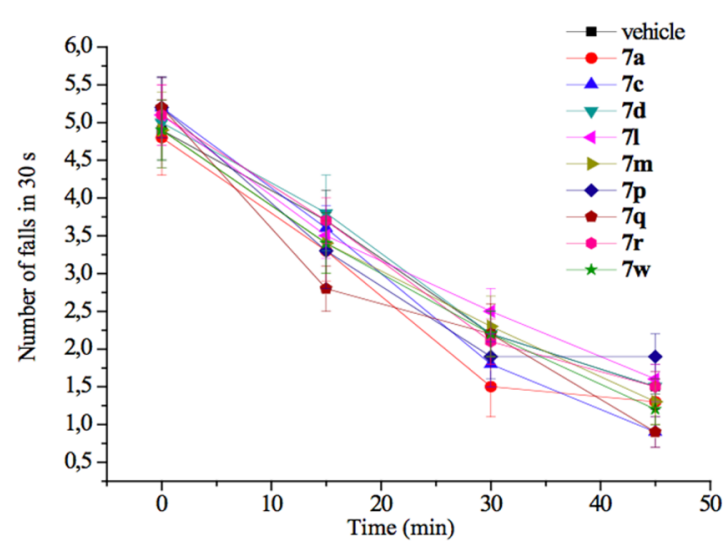

Figure 11. Rota-rod test. Effects on motor coordination. All compounds were administered per os $30 \mathrm{~min}$ before the test. Each value represents the mean \pm SEM of at least 10 mice.

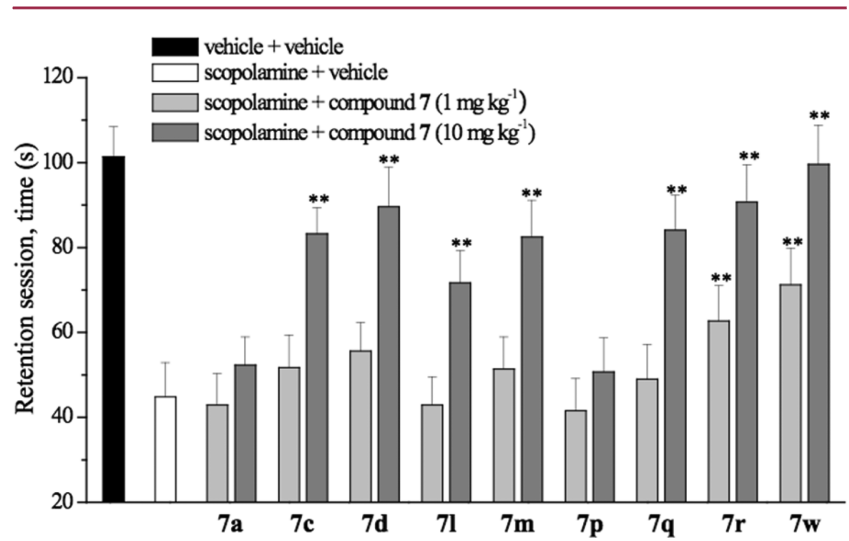

Figure 12. Passive avoidance test. Effects on learning and memory. All compounds were administered per os $30 \mathrm{~min}$ before the test. Scopolamine (1.5 $\mathrm{mg} \mathrm{kg}^{-1}$ intraperitoneally) was administered immediately after the punishment. The time recorded during the retention session is reported. Each value represents the mean \pm SEM of at least 10 mice. $* P<0.05$ and $* * P<0.01$ in comparison to vehicletreated mice.

scopolamine-induced amnesia (Figure 12). Compound $7 \mathbf{w}$ was the most effective $(99.6 \pm 9.2 \mathrm{~s})$, and both $7 \mathbf{r}$ and $7 \mathbf{w}$ were effective also at $1 \mathrm{mg} \mathrm{kg}^{-1}$. Compound $7 \mathrm{~d}$ was effective starting from $3 \mathrm{mg} \mathrm{kg}^{-1}\left(73.5 \pm 8.8 \mathrm{~s}\right.$; data not shown). Ten $\mathrm{mg} \mathrm{kg}^{-1}$ compound $7 \mathbf{p}$ was not effective in the passive avoidance test (Figure 12). However, the dose of $30 \mathrm{mg} \mathrm{kg}^{-1}$ increased the time of the retention session up to $77.9 \pm 7.8 \mathrm{~s}$ (data not shown), while $7 \mathbf{a}$ was ineffective (Figure 12).

\section{CONCLUSION}

The structural analogies existing between $\mathrm{GABA}_{\mathrm{A}}$ and $5-\mathrm{HT}_{3}$ receptors suggested the application of the approach we used in studying $5-\mathrm{HT}_{3}$ receptors to the characterization of CBR interaction features. Thus, a series of imidazo[1,5-a]quinoline derivatives related to 5 (a previously described drug candidate for the treatment of anxiety) was designed, synthesized, and biologically characterized in comparison with reference imidazo[1,5-a]quinoxalines 10a-d. Most of the newly synthesized compounds showed high CBR affinity with $K_{\mathrm{i}}$ values within the submicromolar and the subnanomolar ranges and interesting SAR trends, which suggested the existence of a large though apparently saturable lipophilic pocket in the CBR binding site region interacting with positions 4 and 5. From another perspective, this result could be interpreted as the evidence of a certain degree of conformational freedom of the amino acid residues interacting with the substituents in positions 4 and 5 of the imidazo[1,5- $a]$ quinoline nucleus. Thus, this promising evidence paves the way to the application of our approach to the study of the $5-\mathrm{HT}_{3}$ receptor to the characterization of the interaction of CBR with divalent and more in general multivalent ligands. ${ }^{60}$ Fluoroderivative $7 \mathbf{w}\left(K_{\mathrm{i}}\right.$ $=0.44 \mathrm{nM})$ resulted the most potent ligand and despite its inverse agonist-antagonist profile suggested by its GABA ratio value of 0.8 , acted as an agonist in the light-dark box test, the classical animal model of anxiety, and was devoid of the undesired myorelaxant side effects. In addition, compound $7 \mathbf{w}$ (at $1 \mathrm{mg} \mathrm{kg}^{-1}$ ) was found to significantly prevent scopolamineinduced amnesia, showing the best efficacy among the compounds evaluated in the in vivo studies $(\mathbf{7 a}, \mathbf{c}, \mathbf{d}, \mathbf{l}, \mathbf{m}, \mathbf{p}, \mathbf{q}, \mathbf{r})$. Furthermore, imidazo[1,5-a] quinoline derivatives $7 \mathbf{l}, \mathbf{q}, \mathbf{r}$, and $\mathbf{8 i}$ showed neuroprotective properties because they reduced LDH release induced by ischemia-like condition in an hormetic-like fashion although with different efficacy windows.

\section{EXPERIMENTAL SECTION}

Chemistry. All chemicals used were of reagent grade. Yields refer to purified products and are not optimized. Melting points were determined in open capillaries on a Gallenkamp apparatus and are uncorrected. Merck silica gel 60 (230-400 mesh) was used for column chromatography. Merck TLC plates, silica gel $60 \mathrm{~F}_{254}$ were used for TLC. NMR spectra were recorded by means of either a Bruker AC 200 or a Bruker DRX 400 AVANCE spectrometers in the indicated solvents (TMS as internal standard); the values of the chemical shifts are expressed in ppm and the coupling constants $(J)$ in $\mathrm{Hz}$.

The purity of compounds $7 \mathbf{a}-\mathbf{a a}, \mathbf{8 a}-\mathbf{i}, \mathbf{9}$, and $\mathbf{1 0 a}-\mathbf{d}$ was assessed by RP-HPLC and was found to be higher than 95\%. An Agilent 1100 series system equipped with a Phenomenex C18 $(3.9 \mathrm{~mm} \times 150 \mathrm{~mm}$, $10 \mu \mathrm{m})$ column or a Zorbax Eclipse XBD-C8 $(4.6 \mathrm{~mm} \times 150 \mathrm{~mm}, 5$ $\mu \mathrm{m})$ column was used in the HPLC analysis with acetonitrilemethanol-water $(10: 20: 70)$ or $(10: 40: 50)$ or $(10: 50: 40)$ or $(10: 70: 20)$ as the mobile phases at a flow rate of $2.0 \mathrm{~mL} / \mathrm{min}$. UV detection was achieved at $254 \mathrm{~nm}$. Mass spectra were recorded on either a Thermo LCQ-Deca or an Agilent 1100 LC/MSD.

General Procedure for the Synthesis of Target Imidazo[1,5a]quinoline Derivatives $7 a-i, k-m, 0-y$. A mixture of the suitable 2chloroquinoline derivative (11-24, 1 equiv) was cooled at $0-5{ }^{\circ} \mathrm{C}$ in dry DMF (typically, $10 \mathrm{~mL}$ for $1 \mathrm{mmol}$ ) under argon and then treated with the suitable isocyanoacetate ( 3 equiv) and potassium tertbutoxide ( 3 equiv). The resulting mixture was stirred for $30 \mathrm{~min}$ at $0-$ $5{ }^{\circ} \mathrm{C}$, then allowed to stir at room temperature for $1 \mathrm{~h}$, and finally heated at $80^{\circ} \mathrm{C}$ for $1-20 \mathrm{~h}$ (following the reaction progress by TLC). 
After cooling to room temperature, acetic acid (typically, $1.0 \mathrm{~mL}$ for 1 mmol) was added and the mixture was stirred for additional $20 \mathrm{~min}$ and then poured onto crushed ice. The precipitate was collected by filtration, washed with water, dissolved into chloroform, and the organic layer washed with brine, dried over $\mathrm{Na}_{2} \mathrm{SO}_{4}$, and concentrated under reduced pressure. The residue was purified by flashchromatography with the suitable eluent to afford the expected imidazo[1,5-a] quinoline derivative $(7 \mathbf{a}-\mathbf{i}, \mathbf{k}-\mathbf{m}, \mathbf{o}-\mathbf{y})$, which after recrystallization from the suitable solvent gave an analytical sample.

Ethyl 5-(Dimethylcarbamoyl)imidazo[1,5-a]quinoline-3-carboxylate (7a). The title compound was obtained as a white solid from $\mathbf{1 1}$ according to the above general procedure and purified by flash chromatography with ethyl acetate as the eluent (yield 35\%). An analytical sample was obtained by recrystallization from ethyl acetatechloroform by slow evaporation (white crystals, mp $\left.209-210{ }^{\circ} \mathrm{C}\right) .{ }^{1} \mathrm{H}$ NMR $\left(400 \mathrm{MHz}, \mathrm{CDCl}_{3}\right): \delta 1.45(\mathrm{t}, J=7.1,3 \mathrm{H}), 2.96(\mathrm{~s}, 3 \mathrm{H}), 3.23$ $(\mathrm{s}, 3 \mathrm{H}), 4.46(\mathrm{q}, J=7.1,2 \mathrm{H}), 7.52(\mathrm{t}, J=7.6,1 \mathrm{H}), 7.63-7.77(\mathrm{~m}, 2 \mathrm{H})$, $8.03(\mathrm{~s}, 1 \mathrm{H}), 8.09(\mathrm{~d}, J=8.3,1 \mathrm{H}), 8.70(\mathrm{~s}, 1 \mathrm{H}) .{ }^{13} \mathrm{C} \mathrm{NMR}(100 \mathrm{MHz}$, $\left.\mathrm{CDCl}_{3}\right): \delta 14.5,35.0,38.9,60.8,115.3,121.2,125.6,126.9,127.0$, 128.4, 130.4, 130.6, 131.2, 132.7, 163.0, 168.0. MS (ESI) $\mathrm{m} / z$ calcd for $\mathrm{C}_{17} \mathrm{H}_{17} \mathrm{~N}_{3} \mathrm{O}_{3} \mathrm{Na}[\mathrm{M}+\mathrm{Na}]^{+}$, 334.1; found, 334.2.

tert-Butyl 5-(Dimethylcarbamoyl)imidazo[1,5-a]quinoline-3-carboxylate (7b). This compound was prepared from 11 according to the above general procedure and purified by flash chromatography with ethyl acetate as the eluent to obtain $\mathbf{7 b}$ as a white solid (yield 59\%, mp $\left.222-223{ }^{\circ} \mathrm{C}\right) .{ }^{1} \mathrm{H}$ NMR $\left(400 \mathrm{MHz}, \mathrm{CDCl}_{3}\right): \delta 1.66(\mathrm{~s}, 9 \mathrm{H}), 2.97(\mathrm{~s}$, $3 \mathrm{H}), 3.22(\mathrm{~s}, 3 \mathrm{H}), 7.51(\mathrm{t}, J=7.6,1 \mathrm{H}), 7.67(\mathrm{t}, J=7.3,1 \mathrm{H}), 7.71(\mathrm{~d}, J$ $=8.0,1 \mathrm{H}), 8.01(\mathrm{~s}, 1 \mathrm{H}), 8.08(\mathrm{~d}, J=8.3,1 \mathrm{H}), 8.66(\mathrm{~s}, 1 \mathrm{H}) .{ }^{13} \mathrm{C}$ NMR $\left(100 \mathrm{MHz}, \mathrm{CDCl}_{3}\right): \delta 28.4,34.9,38.9,81.5,115.3,115.6,121.2,126.8$, 127.0, 128.1, 130.2, 130.6, 130.7, 132.2, 162.4, 168.1. MS (ESI) $\mathrm{m} / \mathrm{z}$ calcd for $\mathrm{C}_{19} \mathrm{H}_{21} \mathrm{~N}_{3} \mathrm{O}_{3} \mathrm{Na}[\mathrm{M}+\mathrm{Na}]^{+}, 362.2$; found, 362.1.

Ethyl 5-[Butyl(methyl)carbamoyl]imidazo[1,5-a]quinoline-3-carboxylate (7c). This compound was synthesized from 12 according to the above general procedure and purified by flash chromatography with ethyl acetate $/ n$-hexane $(9: 1)$ as the eluent to obtain $7 \mathrm{c}$ as a white solid (yield $10 \%, \mathrm{mp} 148-149{ }^{\circ} \mathrm{C}$ ). Because the amide nitrogen of the compound bears two different substituents, its ${ }^{1} \mathrm{H}$ NMR spectrum $\left(\mathrm{CDCl}_{3}\right)$ shows the presence of a (ca. 1:1) mixture of two rotamers in equilibrium; for the sake of simplification, the integral values have not been reported. ${ }^{1} \mathrm{H}$ NMR $\left(400 \mathrm{MHz}, \mathrm{CDCl}_{3}\right): \delta 0.73(\mathrm{t}, J=7.3), 1.03$ (t, $J=7.3), 1.07-1.19(\mathrm{~m}), 1.42-1.58(\mathrm{~m}), 1.67-1.78(\mathrm{~m}), 2.92(\mathrm{~s})$, $3.18-3.25(\mathrm{~m}), 3.61-3.69(\mathrm{~m}), 4.47(\mathrm{q}, J=7.1), 7.50-7.57(\mathrm{~m})$, $7.66-7.77(\mathrm{~m}), 8.02(\mathrm{~s}), 8.03(\mathrm{~s}), 8.10(\mathrm{~d}, J=8.3), 8.71(\mathrm{~s}), 8.72(\mathrm{~s})$. MS (ESI) $\mathrm{m} / z$ calcd for $\mathrm{C}_{20} \mathrm{H}_{23} \mathrm{~N}_{3} \mathrm{O}_{3} \mathrm{Na}[\mathrm{M}+\mathrm{Na}]^{+}, 376.2$; found, 376.0.

tert-Butyl 5-[Butyl(methyl)carbamoyl]imidazo[1,5-a]quinoline-3carboxylate ( $7 d)$. This compound was prepared from 12 according to the above general procedure and purified by flash chromatography with ethyl acetate/n-hexane $(9: 1)$ as the eluent to obtain $7 \mathbf{d}$ as a creamy solid (yield 17\%, mp $148-150{ }^{\circ} \mathrm{C}$ ). Because the amide nitrogen of the compound bears two different substituents, its ${ }^{1} \mathrm{H}$ NMR spectrum $\left(\mathrm{CDCl}_{3}\right)$ shows the presence of a (ca. 1:1) mixture of two rotamers in equilibrium; for the sake of simplification, the integral values have not been reported. ${ }^{1} \mathrm{H}$ NMR $\left(400 \mathrm{MHz}, \mathrm{CDCl}_{3}\right): \delta 0.73$ $(\mathrm{t}, J=7.3), 1.01(\mathrm{t}, J=7.3), 1.07-1.18(\mathrm{~m}), 1.38-1.77(\mathrm{~m}), 2.14(\mathrm{~s})$, $2.92(\mathrm{~s}), 3.18(\mathrm{~s}), 3.19-3.24(\mathrm{~m}), 3.64(\mathrm{t}, J=7.5), 7.47-7.54(\mathrm{~m})$, $7.63-7.73(\mathrm{~m}), 7.97(\mathrm{~s}), 8.08(\mathrm{~d}, J=8.3), 8.68(\mathrm{~s}), 8.69(\mathrm{~s})$. MS (ESI) $m / z$ calcd for $\mathrm{C}_{22} \mathrm{H}_{27} \mathrm{~N}_{3} \mathrm{O}_{3} \mathrm{Na}[\mathrm{M}+\mathrm{Na}]^{+}$, 404.2; found, 404.2.

Ethyl 5-(Dipropylcarbamoyl)imidazo[1,5-a]quinoline-3-carboxylate (7e). The title compound was prepared from $13^{38}$ according to the above general procedure and purified by flash chromatography with $n$-hexane-ethyl acetate $(1: 1)$ as the eluent to obtain $7 \mathbf{e}$ as a white solid (yield $72 \%$, mp $168-169{ }^{\circ} \mathrm{C}$ ). ${ }^{1} \mathrm{H}$ NMR (400 $\mathrm{MHz}, \mathrm{CDCl}_{3}$ ): $\delta$ $0.71(\mathrm{t}, J=7.4,3 \mathrm{H}), 1.04(\mathrm{t}, J=7.4,3 \mathrm{H}), 1.44(\mathrm{t}, J=7.1,3 \mathrm{H}), 1.48-$ $1.59(\mathrm{~m}, 2 \mathrm{H}), 1.72-1.87(\mathrm{~m}, 2 \mathrm{H}), 3.15($ br s, $2 \mathrm{H}), 3.57$ (br s, $2 \mathrm{H})$, $4.46(\mathrm{q}, J=7.1,2 \mathrm{H}), 7.50(\mathrm{t}, J=7.7,1 \mathrm{H}), 7.63-7.69(\mathrm{~m}, 1 \mathrm{H}), 7.72(\mathrm{~d}$, $J=8.1,1 \mathrm{H}), 7.99(\mathrm{~s}, 1 \mathrm{H}), 8.08(\mathrm{~d}, J=8.3,1 \mathrm{H}), 8.68(\mathrm{~s}, 1 \mathrm{H}) . \mathrm{MS}$ (ESI) $m / z$ calcd for $\mathrm{C}_{21} \mathrm{H}_{26} \mathrm{~N}_{3} \mathrm{O}_{3}[\mathrm{M}+\mathrm{H}]^{+}$, 368.2; found, 367.9.

tert-Butyl 5-(Dipropylcarbamoyl)imidazo[1,5-a]quinoline-3-carboxylate (7f). The title compound was prepared from $13^{38}$ according to the above general procedure and purified by flash chromatography with $n$-hexane-ethyl acetate $(1: 1)$ as the eluent to obtain $7 \mathbf{f}$ as a white solid (yield 48\%, mp 159-160 ${ }^{\circ} \mathrm{C}$ ). ${ }^{1} \mathrm{H}$ NMR (400 MHz, $\mathrm{CDCl}_{3}$ ): $\delta$ $0.72(\mathrm{t}, J=7.4,3 \mathrm{H}), 1.05(\mathrm{t}, J=7.4,3 \mathrm{H}), 1.37-1.96(\mathrm{~m}, 13 \mathrm{H}), 3.17$ (br s, $2 \mathrm{H}), 3.57(\mathrm{br} \mathrm{s}, 2 \mathrm{H}), 7.52(\mathrm{t}, J=7.7,1 \mathrm{H}), 7.64-7.70(\mathrm{~m}, 1 \mathrm{H})$, $7.72(\mathrm{~d}, J=8.0,1 \mathrm{H}), 7.96(\mathrm{~s}, 1 \mathrm{H}), 8.08(\mathrm{~d}, J=8.3,1 \mathrm{H}), 8.71(\mathrm{~s}, 1 \mathrm{H})$. MS (ESI) $m / z$ calcd for $\mathrm{C}_{23} \mathrm{H}_{29} \mathrm{~N}_{3} \mathrm{O}_{3} \mathrm{Na}[\mathrm{M}+\mathrm{Na}]^{+}$, 418.2; found, 417.9.

Ethyl 5-[Benzyl(methyl)carbamoyl]imidazo[1,5-a]quinoline-3carboxylate $(7 \mathrm{~g})$. The title compound was prepared from $14^{38}$ according to the above general procedure and purified by flash chromatography with ethyl acetate as the eluent to obtain $7 \mathrm{~g}$ as a white solid (yield 56\%). An analytical sample was obtained by recrystallization from ethyl acetate-chloroform by slow evaporation (mp 198-199 ${ }^{\circ} \mathrm{C}$ ). Because the amide nitrogen of the compound bears two different substituents, its ${ }^{1} \mathrm{H}$ NMR spectrum $\left(\mathrm{CDCl}_{3}\right)$ shows the presence of a (ca. 6:4) mixture of two rotamers in equilibrium; for the sake of simplification, the integral values have not been reported. ${ }^{1} \mathrm{H}$ NMR (400 MHz, $\left.\mathrm{CDCl}_{3}\right): \delta 1.39-1.49(\mathrm{~m}), 2.84(\mathrm{~s}), 3.14(\mathrm{~s})$, $4.38-4.51(\mathrm{~m}), 4.86(\mathrm{~s}), 7.10(\mathrm{~d}, J=7.0), 7.20-7.46(\mathrm{~m}), 7.47-7.56$ (m), 7.63-7.70 (m), 7.73 (d, $J=8.0$ ), 7.82 (d, $J=8.0), 8.04-8.13$ (m), 8.66 (s), 8.67 (s). MS (ESI) $\mathrm{m} / z$ calcd for $\mathrm{C}_{23} \mathrm{H}_{22} \mathrm{~N}_{3} \mathrm{O}_{3}[\mathrm{M}+$ $\mathrm{H}]^{+}, 388.2$; found, 387.9.

tert-Butyl 5-[Benzyl(methyl)carbamoyl]imidazo[1,5-a]quinoline3-carboxylate (7h). The title compound was synthesized from $14^{38}$ according to the above general procedure and purified by flash chromatography with ethyl acetate as the eluent to obtain $7 \mathrm{~h}$ as a white solid (yield $36 \%$, mp $92-93{ }^{\circ} \mathrm{C}$ ). Because the amide nitrogen of the compound bears two different substituents, its ${ }^{1} \mathrm{H}$ NMR spectrum $\left(\mathrm{CDCl}_{3}\right)$ shows the presence of a (ca. 6:4) mixture of two rotamers in equilibrium; for the sake of simplification, the integral values have not been reported. ${ }^{1} \mathrm{H}$ NMR $\left(400 \mathrm{MHz}, \mathrm{CDCl}_{3}\right): \delta 1.65$ (s), $1.66(\mathrm{~s}), 2.86$ (s), $3.14(\mathrm{~s}), 4.48(\mathrm{~s}), 4.86(\mathrm{~s}), 7.11(\mathrm{~d}, J=7.0), 7.19-7.46(\mathrm{~m}), 7.49-$ $7.59(\mathrm{~m}), 7.64-7.72(\mathrm{~m}), 7.75(\mathrm{~d}, J=8.0), 7.82(\mathrm{~d}, J=8.0), 8.00-8.12$ (m), 8.70 (s). MS (ESI) $m / z$ calcd for $\mathrm{C}_{25} \mathrm{H}_{25} \mathrm{~N}_{3} \mathrm{O}_{3} \mathrm{Na}[\mathrm{M}+\mathrm{Na}]^{+}$, 438.2; found, 438.3 .

Ethyl 5-(4-Methylpiperazine-1-carbonyl)imidazo[1,5-a]quinoline3-carboxylate (7i). The title compound was prepared from $15^{40}$ according to the above general procedure and purified by flash chromatography with ethyl acetate-triethylamine $(8: 2)$ as the eluent to obtain $7 \mathbf{i}$ as a white solid (yield $25 \%, \mathrm{mp} 230-231{ }^{\circ} \mathrm{C}$ ). ${ }^{1} \mathrm{H}$ NMR $\left(400 \mathrm{MHz}, \mathrm{CDCl}_{3}\right): \delta 1.44(\mathrm{t}, J=7.1,3 \mathrm{H}), 2.19-2.43(\mathrm{~m}, 5 \mathrm{H}), 2.57$ (br s, 2H), 3.24-3.53 (br m, 2H), 3.93 (br s, $2 \mathrm{H}), 4.46$ (q, $J=7.0$, $2 \mathrm{H}), 7.52(\mathrm{t}, J=7.7,1 \mathrm{H}), 7.67(\mathrm{t}, J=7.8,1 \mathrm{H}), 7.75(\mathrm{~d}, J=8.0,1 \mathrm{H})$, $8.02(\mathrm{~s}, 1 \mathrm{H}), 8.07(\mathrm{~d}, J=8.3,1 \mathrm{H}), 8.64(\mathrm{~s}, 1 \mathrm{H}) .{ }^{13} \mathrm{C}$ NMR $(100 \mathrm{MHz}$, $\left.\mathrm{CDCl}_{3}\right): \delta 14.5,41.7,45.9,47.1,54.7,55.3,60.7,115.3,121.3,125.9$, $126.9,128.4,130.4,130.6,131.1,131.9,163.1,166.5$. MS (ESI) $\mathrm{m} / z$ calcd for $\mathrm{C}_{20} \mathrm{H}_{23} \mathrm{~N}_{4} \mathrm{O}_{3}[\mathrm{M}+\mathrm{H}]^{+}$, 367.2; found, 366.9. Anal. Calcd for $\mathrm{C}_{20} \mathrm{H}_{22} \mathrm{~N}_{4} \mathrm{O}_{3}$ : C, 65.56; H, 6.05; N, 15.29. Found: C, 65.67; H, 6.44; $\mathrm{N}, 15.39$.

3-(Ethoxycarbonyl)-4-methylimidazo[1,5-a]quinoline-5-carboxylic Acid (7j). A mixture of $7 \mathrm{k}(0.37 \mathrm{~g}, 1.04 \mathrm{~mol})$ in formic acid (15 $\mathrm{mL}$ ) was stirred at room temperature overnight and then concentrated under reduced pressure. Purification of the residue by washing with diethyl ether afforded acid $7 \mathbf{j}$ as a white solid $(0.29 \mathrm{~g}$, yield $93 \%, \mathrm{mp}$ dec $\left.>300{ }^{\circ} \mathrm{C}\right) .{ }^{1} \mathrm{H}$ NMR $\left(400 \mathrm{MHz}\right.$, DMSO- $\left.d_{6}\right): \delta 1.31(\mathrm{t}, J=7.0$, $3 \mathrm{H}), 2.59(\mathrm{~s}, 3 \mathrm{H}), 4.30(\mathrm{q}, J=7.0,2 \mathrm{H}), 7.57(\mathrm{t}, J=7.5,1 \mathrm{H}), 7.64(\mathrm{~d}, J$ $=7.8,1 \mathrm{H}), 7.71(\mathrm{t}, J=7.5,1 \mathrm{H}), 8.52(\mathrm{~d}, J=8.3,1 \mathrm{H}), 9.28(\mathrm{~s}, 1 \mathrm{H})$ MS (ESI negative ions) $m / z$ calcd for $\mathrm{C}_{16} \mathrm{H}_{13} \mathrm{~N}_{2} \mathrm{O}_{4}\left[\mathrm{M}-\mathrm{H}^{+}\right]^{-}$, 297.1; found, 297.0.

5-tert-Butyl 3-Ethyl 4-Methylimidazo[1,5-a]quinoline-3,5-dicarboxylate ( $7 \mathrm{k}$ ). The title compound was prepared from 16 according to the above general procedure and purified by flash chromatography with ethyl acetate $-n$-hexane $(8: 2)$ as the eluent to obtain $7 \mathbf{k}$ as a white solid (yield 94\%, mp 197-200 ${ }^{\circ} \mathrm{C}$ ). ${ }^{1} \mathrm{H}$ NMR (400 $\left.\mathrm{MHz} \mathrm{CDCl}_{3}\right): \delta$ $1.47(\mathrm{t}, J=7.1,3 \mathrm{H}), 1.68(\mathrm{~s}, 9 \mathrm{H}), 2.78(\mathrm{~s}, 3 \mathrm{H}), 4.46(\mathrm{q}, J=7.1,2 \mathrm{H})$, $7.52(\mathrm{t}, J=7.6,1 \mathrm{H}), 7.61-7.69(\mathrm{~m}, 2 \mathrm{H}), 8.09(\mathrm{~d}, J=8.3,1 \mathrm{H}), 8.89(\mathrm{~s}$, $1 \mathrm{H})$. MS (ESI) $\mathrm{m} / z$ calcd for $\mathrm{C}_{20} \mathrm{H}_{23} \mathrm{~N}_{2} \mathrm{O}_{4}[\mathrm{M}+\mathrm{H}]^{+}$, 355.2; found, 355.1 . 
Ethyl 5-(Dipropylcarbamoyl)-4-methylimidazo[1,5-a]quinoline3-carboxylate (7I). The title compound was prepared from $17^{38}$ according to the above general procedure and purified by flash chromatography with ethyl acetate as the eluent to obtain 71 as a offwhite solid (yield $60 \%, \mathrm{mp} 173-174{ }^{\circ} \mathrm{C}$ ). ${ }^{1} \mathrm{H}$ NMR $(400 \mathrm{MHz}$, $\left.\mathrm{CDCl}_{3}\right): \delta 0.65(\mathrm{t}, J=7.2,3 \mathrm{H}), 1.05(\mathrm{t}, J=7.2,3 \mathrm{H}), 1.32-1.56(\mathrm{~m}$, $5 \mathrm{H}), 1.74-1.89(\mathrm{~m}, 2 \mathrm{H}), 2.71(\mathrm{~s}, 3 \mathrm{H}), 2.98-3.17(\mathrm{~m}, 2 \mathrm{H}), 3.45-3.72$ $(\mathrm{m}, 2 \mathrm{H}), 4.43(\mathrm{q}, J=7.2,2 \mathrm{H}), 7.44(\mathrm{t}, J=7.5,1 \mathrm{H}), 7.52-7.62(\mathrm{~m}$, $2 \mathrm{H}), 8.03(\mathrm{~d}, J=8.3,1 \mathrm{H}), 8.70(\mathrm{~s}, 1 \mathrm{H})$. MS (ESI) $\mathrm{m} / z$ calcd for $\mathrm{C}_{22} \mathrm{H}_{28} \mathrm{~N}_{3} \mathrm{O}_{3}[\mathrm{M}+\mathrm{H}]^{+}, 382.2$; found, 381.9. Anal. Calcd for $\mathrm{C}_{22} \mathrm{H}_{27} \mathrm{~N}_{3} \mathrm{O}_{3}$ : C, 69.27; H, 7.13; N, 11.02. Found: C, 69.13; H, 7.34; $\mathrm{N}, 11.19$.

tert-Butyl 5-(Dipropylcarbamoyl)-4-methylimidazo[1,5-a]quinoline-3-carboxylate $(7 \mathrm{~m})$. The title compound was prepared from $17^{38}$ according to the above general procedure and purified by flash chromatography with ethyl acetate as the eluent to obtain $7 \mathrm{~m}$ as a white solid (yield $46 \%, \mathrm{mp} 138-139{ }^{\circ} \mathrm{C}$ ). ${ }^{1} \mathrm{H}$ NMR (400 $\mathrm{MHz}$, $\left.\mathrm{CDCl}_{3}\right): \delta 0.66(\mathrm{t}, J=7.4,3 \mathrm{H}), 1.05(\mathrm{t}, J=7.4,3 \mathrm{H}), 1.31-1.55(\mathrm{~m}$, $2 \mathrm{H}), 1.66(\mathrm{~s}, 9 \mathrm{H}), 1.75-1.90(\mathrm{~m}, 2 \mathrm{H}), 2.66(\mathrm{~s}, 3 \mathrm{H}), 2.99-3.18(\mathrm{~m}$, $2 \mathrm{H}), 3.45-3.56(\mathrm{~m}, 1 \mathrm{H}), 3.62-3.74(\mathrm{~m}, 1 \mathrm{H}), 7.45(\mathrm{t}, J=7.6,1 \mathrm{H})$, 7.53-7.63 (m, 2H), $8.01(\mathrm{~d}, J=8.3,1 \mathrm{H}), 8.65(\mathrm{~s}, 1 \mathrm{H})$. MS (ESI) $\mathrm{m} / z$ calcd for $\mathrm{C}_{24} \mathrm{H}_{31} \mathrm{~N}_{3} \mathrm{O}_{3} \mathrm{Na}[\mathrm{M}+\mathrm{Na}]^{+}$, 432.2; found, 432.1. Anal. Calcd for $\mathrm{C}_{24} \mathrm{H}_{31} \mathrm{~N}_{3} \mathrm{O}_{3}$ : C, 70.39; H, 7.63; N, 10.26. Found: C, 70.22; H, 7.44; N, 10.23 .

Ethyl 4-Methyl-5-[methyl(prop-2-ynyl)carbamoyl]imidazo[1,5-a]quinoline-3-carboxylate (7n). A mixture of acid $7 \mathbf{j}(0.80 \mathrm{~g}, 2.68$ $\mathrm{mmol}$ ) in $6.0 \mathrm{~mL}$ of thionyl chloride was heated to reflux for $3 \mathrm{~h}$ and then concentrated under reduced pressure. The residue was dissolved into $6.0 \mathrm{~mL}$ of dichloromethane, and the resulting solution was treated with $\mathrm{N}$-methylpropargylamine $(0.43 \mathrm{~mL}, 5.1 \mathrm{mmol})$. The reaction mixture was stirred at room temperature for $30 \mathrm{~min}$ and then partitioned between dichloromethane and water. The organic layer was washed with water, dried over sodium sulfate, and concentrated under reduced pressure. The resulting residue was purified by flash chromatography with $n$-hexane-ethyl acetate $(1: 1)$ as the eluent to obtain $7 \mathbf{n}$ as a white solid $\left(0.82\right.$ g, yield $88 \%$, mp $\left.219-220{ }^{\circ} \mathrm{C}\right)$. The ${ }^{1} \mathrm{H}$ NMR spectrum $\left(\mathrm{CDCl}_{3}\right)$ of the compound shows the presence of the minor rotamer only in low amount. For the sake of simplification, only the signals of the major rotamer have been reported. ${ }^{1} \mathrm{H}$ NMR $\left(400 \mathrm{MHz}, \mathrm{CDCl}_{3}\right): \delta 1.46(\mathrm{t}, J=7.1,3 \mathrm{H}), 2.34(\mathrm{br} \mathrm{s}, 1 \mathrm{H}), 2.72(\mathrm{~s}$, $3 \mathrm{H}), 2.94(\mathrm{~s}, 3 \mathrm{H}), 4.38-4.51(\mathrm{~m}, 3 \mathrm{H}), 4.59(\mathrm{~d}, J=17.2,1 \mathrm{H}), 7.45-$ $7.51(\mathrm{~m}, 1 \mathrm{H}), 7.55(\mathrm{~d}, J=8.0,1 \mathrm{H}), 7.62(\mathrm{t}, J=7.7,1 \mathrm{H}), 8.04(\mathrm{~d}, J=$ 8.3, $1 \mathrm{H}), 8.68(\mathrm{~s}, 1 \mathrm{H})$. MS (ESI) $\mathrm{m} / z$ calcd for $\mathrm{C}_{20} \mathrm{H}_{20} \mathrm{~N}_{3} \mathrm{O}_{3}[\mathrm{M}+$ $\mathrm{H}]^{+}, 350.2$; found, 349.9 .

Ethyl 5-[Benzyl(methyl)carbamoyl]-4-methylimidazo[1,5-a]quinoline-3-carboxylate (70). The title compound was prepared from $18^{38}$ according to the above general procedure and purified by flash chromatography with ethyl acetate- $n$-hexane $(8: 2)$ as the eluent to obtain $7 \mathrm{o}$ as a white solid (yield $26 \%, \mathrm{mp} 214-215{ }^{\circ} \mathrm{C}$ ). The ${ }^{1} \mathrm{H}$ NMR spectrum $\left(\mathrm{CDCl}_{3}\right)$ of the compound shows the presence of the minor rotamer only in trace amounts. For the sake of simplification, only the signals of the major rotamer have been reported. ${ }^{1} \mathrm{H}$ NMR $\left(400 \mathrm{MHz}, \mathrm{CDCl}_{3}\right): \delta 1.44(\mathrm{t}, J=7.1,3 \mathrm{H}), 2.70(\mathrm{~s}, 3 \mathrm{H}), 2.75(\mathrm{~s}, 3 \mathrm{H})$, $4.42(\mathrm{q}, J=7.1,2 \mathrm{H}), 4.79(\mathrm{~d}, J=14.1,1 \mathrm{H}), 4.99(\mathrm{~d}, J=14.1,1 \mathrm{H})$, $7.30-7.61(\mathrm{~m}, 8 \mathrm{H}), 8.02(\mathrm{~d}, J=8.3,1 \mathrm{H}), 8.69(\mathrm{~s}, 1 \mathrm{H})$. MS $($ ESI $) \mathrm{m} / z$ calcd for $\mathrm{C}_{24} \mathrm{H}_{24} \mathrm{~N}_{3} \mathrm{O}_{3}[\mathrm{M}+\mathrm{H}]^{+}$, 402.2; found, 401.9.

tert-Butyl 5-[Benzyl(methyl)carbamoyl]-4-methylimidazo[1,5-a]quinoline-3-carboxylate (7p). The title compound was prepared from $\mathbf{1 8}^{38}$ according to the above general procedure and purified by flash chromatography with ethyl acetate $-n$-hexane $(8: 2)$ as the eluent to obtain $7 \mathrm{p}$ as a white solid (yield $46 \%$, mp $123-126^{\circ} \mathrm{C}$ ). The ${ }^{1} \mathrm{H}$ NMR spectrum $\left(\mathrm{CDCl}_{3}\right)$ of the compound shows the presence of the minor rotamer only in trace amounts. For the sake of simplification, only the signals of the major rotamer have been reported. ${ }^{1} \mathrm{H}$ NMR $(400 \mathrm{MHz}$, $\left.\mathrm{CDCl}_{3}\right): \delta 1.64(\mathrm{~s}, 9 \mathrm{H}), 2.64(\mathrm{~s}, 3 \mathrm{H}), 2.74(\mathrm{~s}, 3 \mathrm{H}), 4.74(\mathrm{~d}, J=14.1$, $1 \mathrm{H}), 5.01(\mathrm{~d}, J=14.1,1 \mathrm{H}), 7.29-7.58(\mathrm{~m}, 8 \mathrm{H}), 7.99(\mathrm{~d}, J=8.3,1 \mathrm{H})$, 8.65 (s, $1 \mathrm{H}$ ). MS (ESI) $\mathrm{m} / z$ calcd for $\mathrm{C}_{26} \mathrm{H}_{28} \mathrm{~N}_{3} \mathrm{O}_{3}[\mathrm{M}+\mathrm{H}]^{+}$, 430.2; found, 429.9 .

Ethyl 5-(Dipropylcarbamoyl)-4-ethylimidazo[1,5-a]quinoline-3carboxylate (7q). The title compound was prepared from $19^{38}$ according to the above general procedure and purified by flash chromatography with ethyl acetate- $n$-hexane $(7: 3)$ as the eluent to obtain $7 \mathbf{q}$ as a white solid (yield $27 \%, \mathrm{mp} 114-115{ }^{\circ} \mathrm{C}$ ). ${ }^{1} \mathrm{H}$ NMR $\left(400 \mathrm{MHz}, \mathrm{CDCl}_{3}\right): \delta 0.65(\mathrm{t}, J=7.4,3 \mathrm{H}), 1.06(\mathrm{t}, J=7.4,3 \mathrm{H}), 1.21$ $(\mathrm{t}, J=7.4,3 \mathrm{H}), 1.33-1.57(\mathrm{~m}, 5 \mathrm{H}), 1.74-1.90(\mathrm{~m}, 2 \mathrm{H}), 2.74-2.88$ $(\mathrm{m}, 1 \mathrm{H}), 2.96-3.16(\mathrm{~m}, 2 \mathrm{H}), 3.46-3.59(\mathrm{~m}, 1 \mathrm{H}), 3.61-3.78(\mathrm{~m}, 2 \mathrm{H})$, $4.38-4.55(\mathrm{~m}, 2 \mathrm{H}), 7.48(\mathrm{t}, J=7.6,1 \mathrm{H}), 7.55-7.65(\mathrm{~m}, 2 \mathrm{H}), 8.06(\mathrm{~d}$, $J=8.3,1 \mathrm{H}), 8.79(\mathrm{~s}, 1 \mathrm{H})$. MS (ESI) $\mathrm{m} / z$ calcd for $\mathrm{C}_{23} \mathrm{H}_{29} \mathrm{~N}_{3} \mathrm{O}_{3} \mathrm{Na}[\mathrm{M}$ $+\mathrm{Na}]^{+}, 418.2$; found, 418.3. Anal. Calcd for $\mathrm{C}_{23} \mathrm{H}_{29} \mathrm{~N}_{3} \mathrm{O}_{3} \cdot 0.25 \mathrm{H}_{2} \mathrm{O}: \mathrm{C}$, 69.06; H, 7.43; N, 10.51. Found: C, 69.14; H, 7.50; N, 10.25 .

tert-Butyl 5-(Dipropylcarbamoyl)-4-ethylimidazo[1,5-a]quinoline-3-carboxylate (7r). The title compound was prepared from $19^{38}$ according to the above general procedure and purified by flash chromatography with ethyl acetate $-n$-hexane $(8: 2)$ as the eluent to obtain $7 \mathbf{r}$ as white crystals (yield $15 \%$, mp $160-161^{\circ} \mathrm{C}$ ). ${ }^{1} \mathrm{H}$ NMR $\left(400 \mathrm{MHz}, \mathrm{CDCl}_{3}\right): \delta 0.65(\mathrm{t}, J=7.4,3 \mathrm{H}), 1.05(\mathrm{t}, J=7.4,3 \mathrm{H}), 1.18$ $(\mathrm{t}, J=7.4,3 \mathrm{H}), 1.30-1.56(\mathrm{~m}, 2 \mathrm{H}), 1.67(\mathrm{~s}, 9 \mathrm{H}), 1.76-1.89(\mathrm{~m}, 2 \mathrm{H})$, $2.71-2.77(\mathrm{~m}, 1 \mathrm{H}), 2.97-3.15(\mathrm{~m}, 2 \mathrm{H}), 3.46-3.57(\mathrm{~m}, 1 \mathrm{H}), 3.61-$ $3.72(\mathrm{~m}, 2 \mathrm{H}), 7.45(\mathrm{t}, J=7.6,1 \mathrm{H}), 7.52-7.61(\mathrm{~m}, 2 \mathrm{H}), 8.02(\mathrm{~d}, J=$ 8.3, $1 \mathrm{H}), 8.67(\mathrm{~s}, 1 \mathrm{H})$. MS (ESI) $m / z$ calcd for $\mathrm{C}_{25} \mathrm{H}_{33} \mathrm{~N}_{3} \mathrm{O}_{3} \mathrm{Na}[\mathrm{M}+$ $\mathrm{Na}]^{+}$, 446.2; found, 446.1. Anal. Calcd for $\mathrm{C}_{25} \mathrm{H}_{33} \mathrm{~N}_{3} \mathrm{O}_{3}: \mathrm{C}, 70.89$; $\mathrm{H}$, 7.85; N, 9.92. Found: C, 71.18; H, 8.15; N, 9.82.

Ethyl 5-(Diethylcarbamoyl)-4-propylimidazo[1,5-a]quinoline-3carboxylate (7s). The title compound was prepared from $\mathbf{2 0}^{38}$ according to the above general procedure and purified by flash chromatography with ethyl acetate- $n$-hexane $(8: 2)$ as the eluent to obtain $7 \mathbf{s}$ as a white solid (yield $21 \%$ ). An analytical sample was obtained by recrystallization from diethyl ether by slow evaporation (X-ray quality pale-yellow crystals, mp $\left.103-104{ }^{\circ} \mathrm{C}\right) .{ }^{1} \mathrm{H}$ NMR (400 $\left.\mathrm{MHz} \mathrm{CDCl}_{3}\right): \delta 0.92-1.07(\mathrm{~m}, 6 \mathrm{H}), 1.36(\mathrm{t}, J=7.1,3 \mathrm{H}), 1.43(\mathrm{t}, J=$ 7.1, 3H), 1.50-1.67 (m, 2H), 2.61-2.79 (m, $1 \mathrm{H}), 3.07-3.30(\mathrm{~m}, 2 \mathrm{H})$, $3.50-3.69(\mathrm{~m}, 2 \mathrm{H}), 3.75-3.89(\mathrm{~m}, 1 \mathrm{H}), 4.35-4.53(\mathrm{~m}, 2 \mathrm{H}), 7.43(\mathrm{t}, J$ $=7.5,1 \mathrm{H}), 7.52-7.60(\mathrm{~m}, 2 \mathrm{H}), 8.01(\mathrm{~d}, J=8.2,1 \mathrm{H}), 8.67(\mathrm{~s}, 1 \mathrm{H}) .{ }^{13} \mathrm{C}$ NMR $\left(100 \mathrm{MHz}, \mathrm{CDCl}_{3}\right): \delta 12.7,14.0,14.1,14.5,23.6,33.1,38.9$, 43.0, 61.1, 114.9, 121.6, 126.3, 126.6, 127.2, 128.0, 128.5, 129.2, 129.5, 130.4, 130.7, 163.4, 167.3. MS (ESI) $m / z$ calcd for $\mathrm{C}_{22} \mathrm{H}_{28} \mathrm{~N}_{3} \mathrm{O}_{3}[\mathrm{M}+$ $\mathrm{H}]^{+}$, 382.2; found, 381.9. Anal. Calcd for $\mathrm{C}_{22} \mathrm{H}_{27} \mathrm{~N}_{3} \mathrm{O}_{3}$ : C, 69.27; $\mathrm{H}$, 7.13; N, 11.02. Found: C, 69.45; H, 7.40; N, 11.05 .

tert-Butyl 5-(Diethylcarbamoyl)-4-propylimidazo [1,5-a]quinoline-3-carboxylate (7t). The title compound was prepared from $20^{38}$ according to the above general procedure and purified by flash chromatography with ethyl acetate- $n$-hexane $(8: 2)$ as the eluent to obtain $7 \mathbf{t}$ as a white solid (yield 55\%). An analytical sample was obtained by recrystallization from diethyl ether by slow evaporation (X-ray quality pale-yellow prisms, mp $\left.142-143{ }^{\circ} \mathrm{C}\right) .{ }^{1} \mathrm{H}$ NMR $(400$ $\left.\left.\mathrm{MHz}^{\mathrm{CDCl}}\right)_{3}\right): \delta 0.89-1.05(\mathrm{~m}, 6 \mathrm{H}), 1.35(\mathrm{t}, J=7.0,3 \mathrm{H}), 1.48-1.58$ $(\mathrm{m}, 2 \mathrm{H}), 1.64(\mathrm{~s}, 9 \mathrm{H}), 2.55-2.74(\mathrm{~m}, 1 \mathrm{H}), 3.07-3.31(\mathrm{~m}, 2 \mathrm{H}), 3.50-$ $3.65(\mathrm{~m}, 2 \mathrm{H}), 3.72-3.85(\mathrm{~m}, 1 \mathrm{H}), 7.41(\mathrm{t}, J=7.5,1 \mathrm{H}), 7.51-7.61(\mathrm{~m}$, $2 \mathrm{H}), 7.99(\mathrm{~d}, J=8.2,1 \mathrm{H}), 8.63(\mathrm{~s}, 1 \mathrm{H}) .{ }^{13} \mathrm{C}$ NMR $(100 \mathrm{MHz}$, $\left.\mathrm{CDCl}_{3}\right): \delta 12.7,14.0,23.2,28.3,32.9,38.9,43.0,81.5,114.8,121.6$, $126.3,126.4,127.7,128.5,129.0,129.1,129.2,129.5,130.0,163.3$ 167.4. MS (ESI) $m / z$ calcd for $\mathrm{C}_{24} \mathrm{H}_{31} \mathrm{~N}_{3} \mathrm{O}_{3} \mathrm{Na}[\mathrm{M}+\mathrm{Na}]^{+}$, 432.2; found, 431.9. Anal. Calcd for $\mathrm{C}_{24} \mathrm{H}_{31} \mathrm{~N}_{3} \mathrm{O}_{3}$ : C, 70.39; $\mathrm{H}, 7.63 ; \mathrm{N}, 10.26$. Found: C, 70.62; H, 7.90; N, 10.00 .

Ethyl 5-(Dipropylcarbamoyl)-4-propylimidazo[1,5-a]quinoline-3carboxylate (7u). The title compound was prepared from $2 \mathbf{1}^{38}$ according to the above general procedure and purified by flash chromatography with ethyl acetate $-n$-hexane $(8: 2)$ as the eluent to obtain $7 \mathbf{u}$ as a white solid (yield $\left.5 \%, \mathrm{mp} 143-144{ }^{\circ} \mathrm{C}\right) .{ }^{1} \mathrm{H}$ NMR (400 $\left.\mathrm{MHz}, \mathrm{CDCl}_{3}\right): \delta 0.63(\mathrm{t}, J=7.1,3 \mathrm{H}), 0.98(\mathrm{t}, J=7.0,3 \mathrm{H}), 1.04(\mathrm{t}, J=$ 7.1, 3H), 1.31-1.51 (m, 5H), 1.53-1.64 (m, 2H), 1.74-1.89 (m, 2H), $2.58-2.72(\mathrm{~m}, 1 \mathrm{H}), 2.98-3.16(\mathrm{~m}, 2 \mathrm{H}), 3.37-3.51(\mathrm{~m}, 1 \mathrm{H}), 3.60-$ $3.81(\mathrm{~m}, 2 \mathrm{H}), 4.38-4.52(\mathrm{~m}, 2 \mathrm{H}), 7.43(\mathrm{t}, J=7.4,1 \mathrm{H}), 7.51-7.63(\mathrm{~m}$, $2 \mathrm{H}), 8.01(\mathrm{~d}, J=7.9,1 \mathrm{H}), 8.69(\mathrm{~s}, 1 \mathrm{H}) .{ }^{13} \mathrm{C}$ NMR $(100 \mathrm{MHz}$, $\left.\mathrm{CDCl}_{3}\right): \delta 11.3,11.7,14.1,14.5,20.6,21.7,23.6,33.2,46.4,50.6,61.1$, $114.8,121.6,126.5,127.2,128.0,128.5,129.2,129.5,130.4,130.7$, 163.4, 167.7. MS (ESI) $m / z$ calcd for $\mathrm{C}_{24} \mathrm{H}_{32} \mathrm{~N}_{3} \mathrm{O}_{3}[\mathrm{M}+\mathrm{H}]^{+}, 410.2$; found, 409.9. Anal. Calcd for $\mathrm{C}_{24} \mathrm{H}_{31} \mathrm{~N}_{3} \mathrm{O}_{3}: \mathrm{C}, 70.39 ; \mathrm{H}, 7.63 ; \mathrm{N}, 10.26$. Found: C, 70.01; H, 7.83; N, 10.21. 
tert-Butyl 5-(Dipropylcarbamoyl)-4-propylimidazo[1,5-a]quinoline-3-carboxylate (7v). The title compound was prepared from $21^{38}$ according to the above general procedure and purified by flash chromatography with ethyl acetate $-n$-hexane $(8: 2)$ as the eluent to obtain $7 \mathbf{v}$ as a white solid (yield $4 \%, \mathrm{mp} 163-164{ }^{\circ} \mathrm{C}$ ). ${ }^{1} \mathrm{H}$ NMR $\left(400 \mathrm{MHz}, \mathrm{CDCl}_{3}\right): \delta 0.64(\mathrm{t}, J=6.5,3 \mathrm{H}), 0.96(\mathrm{t}, J=6.3,3 \mathrm{H}), 1.04$ (t, $J=6.5,3 \mathrm{H}), 1.32-1.93(\mathrm{~m}, 15 \mathrm{H}), 2.46-2.69(\mathrm{~m}, 1 \mathrm{H}), 2.94-3.22$ $(\mathrm{m}, 2 \mathrm{H}), 3.33-3.51(\mathrm{~m}, 1 \mathrm{H}), 3.58-3.85(\mathrm{~m}, 2 \mathrm{H}), 7.42(\mathrm{t}, J=6.9$, $1 \mathrm{H}), 7.51-7.62(\mathrm{~m}, 2 \mathrm{H}), 8.00(\mathrm{~d}, J=7.9,1 \mathrm{H}), 8.64(\mathrm{~s}, 1 \mathrm{H}) .{ }^{13} \mathrm{C}$ NMR $\left(100 \mathrm{MHz}, \mathrm{CDCl}_{3}\right): \delta 11.3,11.7,14.0,20.6,21.8,23.2,28.3,33.0$, 46.4, 50.6, 81.5, 114.8, 121.6, 126.4, 126.5, 127.6, 128.5, 129.0, 129.1, 129.2, 129.5, 130.0, 163.3, 167.8. MS (ESI) $\mathrm{m} / z$ calcd for $\mathrm{C}_{26} \mathrm{H}_{36} \mathrm{~N}_{3} \mathrm{O}_{3}$ $[\mathrm{M}+\mathrm{H}]^{+}$, 438.3; found, 437.9. Anal. Calcd for $\mathrm{C}_{26} \mathrm{H}_{35} \mathrm{~N}_{3} \mathrm{O}_{3}$ : C, 71.37; $\mathrm{H}, 8.06 ; \mathrm{N}, 9.60$. Found: C, 71.70; H, 8.25; N, 9.46.

Ethyl 5-(Dipropylcarbamoyl)-7-fluoroimidazo[1,5-a]quinoline-3carboxylate (7w). The title compound was prepared from 22 according to the above general procedure and purified by flash chromatography with $n$-hexane-ethyl acetate $(1: 1)$ as the eluent to obtain $7 \mathbf{w}$ as a off-white solid (yield $21 \%, \mathrm{mp} 175-177^{\circ} \mathrm{C}$ ). ${ }^{1} \mathrm{H}$ NMR $\left(400 \mathrm{MHz}, \mathrm{CDCl}_{3}\right): \delta 0.71(\mathrm{t}, J=7.3,3 \mathrm{H}), 1.03(\mathrm{t}, J=7.3,3 \mathrm{H}), 1.43$ (t, $J=7.1,3 \mathrm{H}), 1.47-1.59(\mathrm{~m}, 2 \mathrm{H}), 1.72-1.85(\mathrm{~m}, 2 \mathrm{H}), 3.09-3.22$ (m, $2 \mathrm{H}), 3.55(\mathrm{br} \mathrm{s}, 2 \mathrm{H}), 4.45(\mathrm{q}, J=7.1,2 \mathrm{H}), 7.33-7.42(\mathrm{~m}, 2 \mathrm{H})$, $8.02(\mathrm{~s}, 1 \mathrm{H}), 8.05-8.13(\mathrm{~m}, 1 \mathrm{H}), 8.62(\mathrm{~s}, 1 \mathrm{H}) . \mathrm{MS}(\mathrm{ESI}) \mathrm{m} / z$ calcd for $\mathrm{C}_{21} \mathrm{H}_{24} \mathrm{FN}_{3} \mathrm{O}_{3} \mathrm{Na}[\mathrm{M}+\mathrm{Na}]^{+}$, 408.2; found, 408.5.

Ethyl 5-[Benzyl(methyl)carbamoyl]-7-fluoroimidazo[1,5-a]quinoline-3-carboxylate (7x). The title compound was prepared from 23 according to the above general procedure and purified by flash chromatography with ethyl acetate- $n$-hexane $(8: 2)$ as the eluent to obtain $7 \mathbf{x}$ as a white solid (yield $15 \%$ ). An analytical sample was obtained by recrystallization from ethyl acetate-dichloromethane by slow evaporation (mp $180-182{ }^{\circ} \mathrm{C}$ ). Because the amide nitrogen of the compound bears two different substituents, its ${ }^{1} \mathrm{H}$ NMR spectrum $\left(\mathrm{CDCl}_{3}\right)$ shows the presence of a (ca. 6:4) mixture of two rotamers in equilibrium; for the sake of simplification, the integral values have not been reported. ${ }^{1} \mathrm{H}$ NMR $\left(400 \mathrm{MHz}, \mathrm{CDCl}_{3}\right): \delta 1.39-1.52(\mathrm{~m}), 2.87$ (s), $3.16(\mathrm{~s}), 4.36-4.49(\mathrm{~m}), 4.50(\mathrm{~s}), 4.86(\mathrm{~s}), 7.11(\mathrm{~d}, J=7.1), 7.21-$ $7.55(\mathrm{~m}), 8.04-8.10(\mathrm{~m}), 8.11(\mathrm{~s}), 8.14(\mathrm{~s}), 8.62(\mathrm{~s}), 8.63(\mathrm{~s}) . \mathrm{MS}$ (ESI) $\mathrm{m} / z$ calcd for $\mathrm{C}_{23} \mathrm{H}_{21} \mathrm{FN}_{3} \mathrm{O}_{3}[\mathrm{M}+\mathrm{H}]^{+}$, 406.2; found, 406.3.

Ethyl 5-[Benzyl(methyl)carbamoyl]-7-bromoimidazo[1,5-a]quinoline-3-carboxylate (7y). The title compound was prepared from 24 according to the above general procedure (except that the reaction was carried out at $0-5{ }^{\circ} \mathrm{C}$ for $2 \mathrm{~h}$ and then at room temperature for $2 \mathrm{~h}$ ) and purified by flash chromatography with ethyl acetate-petroleum ether $(7: 3)$ as the eluent to obtain $7 \mathbf{y}$ as a white solid (yield $62 \%$, mp $177-178{ }^{\circ} \mathrm{C}$ ). Because the amide nitrogen of the compound bears two different substituents, its ${ }^{1} \mathrm{H}$ NMR spectrum $\left(\mathrm{CDCl}_{3}\right)$ shows the presence of a (ca. 6:4) mixture of two rotamers in equilibrium; for the sake of simplification, the integral values have not been reported. ${ }^{1} \mathrm{H}$ NMR $\left(400 \mathrm{MHz}, \mathrm{CDCl}_{3}\right): \delta 1.32-1.49(\mathrm{~m}), 2.86$ (s), $3.18(\mathrm{~s}), 4.34-4.57(\mathrm{~m}), 4.87(\mathrm{~s}), 7.09-7.12(\mathrm{~m}), 7.22-7.54(\mathrm{~m})$, 7.78 (d, $J=8.2$ ), 7.86-8.16 (m), 8.63 (s). MS (ESI) $\mathrm{m} / z$ calcd for $\mathrm{C}_{23} \mathrm{H}_{21} \mathrm{BrN}_{3} \mathrm{O}_{3}[\mathrm{M}+\mathrm{H}]^{+}$, 466.1; found, 466.3 .

Ethyl 5-[Benzyl(methyl)carbamoyl]-7-[(trimethylsilyl)ethynyl]imidazo[1,5-a]quinoline-3-carboxylate (7aa). To a solution of $7 \mathbf{y}$ $(25 \mathrm{mg}, 0.0536 \mathrm{mmol})$ in dry TEA $(5.0 \mathrm{~mL})$, ethynyltrimethylsilane $(0.045 \mathrm{~mL}, 0.32 \mathrm{mmol})$ and $\mathrm{Pd}\left(\mathrm{PPh}_{3}\right)_{2}(\mathrm{OAc})_{2}(4.0 \mathrm{mg}, 0.0053 \mathrm{mmol})$ were added. The reaction mixture was allowed to stir at room temperature for $30 \mathrm{~min}$, then refluxed for $20 \mathrm{~h}$, and finally filtered and concentrated under reduced pressure. The residue was dissolved into dichloromethane, and the organic layer was washed with a saturated solution of sodium bicarbonate, dried over sodium sulfate, and concentrated under reduced pressure. Purification of the residue by flash chromatography with ethyl acetate- $n$-hexane (7:3) as the eluent gave 7 aa as an oil which slowly crystallized on standing $(12 \mathrm{mg}$, yield $46 \%$ ). Because the amide nitrogen of this compound bears two different substituents, its ${ }^{1} \mathrm{H}$ NMR spectrum shows the presence of a (ca. 6:4) mixture of two different rotamers in equilibrium; for the sake of simplification, the integral values have not been given. ${ }^{1} \mathrm{H}$ NMR $\left(400 \mathrm{MHz}, \mathrm{CDCl}_{3}\right): \delta 0.29(\mathrm{~s}), 1.38-1.48(\mathrm{~m}), 2.86(\mathrm{~s}), 3.19$ (s), 4.36-4.55 (m), $4.88(\mathrm{~s}), 7.13$ (d, $J=7.5), 7.18-7.50(\mathrm{~m}), 7.75(\mathrm{~d}, J=$
8.7), 7.83 (s), 7.90 (s), 7.95-8.12 (m), 8.61 (s), 8.62 (s). MS (ESI) $m / z$ calcd for $\mathrm{C}_{28} \mathrm{H}_{30} \mathrm{~N}_{3} \mathrm{O}_{3} \mathrm{Si}[\mathrm{M}+\mathrm{H}]^{+}$, 484.2; found, 484.4.

Ethyl 5-[Benzyl(methyl)carbamoyl]-7-ethynylimidazo[1,5-a]quinoline-3-carboxylate (7z). To a solution of $7 \mathbf{a a}(50 \mathrm{mg}, 0.103$ $\mathrm{mmol})$ in THF $(15 \mathrm{~mL})$, a solution $\left(1 \mathrm{M}\right.$ in THF) of $\mathrm{Bu}_{4} \mathrm{NF}(0.12$ $\mathrm{mL}, 0.12 \mathrm{mmol}$ ) was added. The reaction mixture was stirred at room temperature for $1 \mathrm{~h}$, then diluted with water and extracted with ethyl acetate. The organic layer was washed with brine, dried over sodium sulfate, and concentrated under reduced pressure. Purification of the residue by flash chromatography with ethyl acetate as the eluent gave $7 \mathbf{z}$ as a yellow glassy solid ( $21 \mathrm{mg}$, yield $49 \%$ ). Because the amide nitrogen of this compound bears two different substituents, its ${ }^{1} \mathrm{H}$ NMR spectrum shows the presence of a (ca. 6:4) mixture of two different rotamers in equilibrium; for the sake of simplification, the integral values have not been given. ${ }^{1} \mathrm{H}$ NMR $\left(400 \mathrm{MHz}, \mathrm{CDCl}_{3}\right): \delta$ 1.39-1.49 (m), $2.86(\mathrm{~s}), 3.18(\mathrm{~s}), 3.19(\mathrm{~s}), 3.22(\mathrm{~s}), 4.40-4.51(\mathrm{~m})$, $4.87(\mathrm{~s}), 7.12(\mathrm{~d}, J=7.2), 7.22-7.49(\mathrm{~m}), 7.77(\mathrm{~d}, J=8.2), 7.88(\mathrm{~s})$, $7.95(\mathrm{~s}), 7.98-8.12(\mathrm{~m}), 8.63(\mathrm{~s}), 8.64(\mathrm{~s})$. MS (ESI) $\mathrm{m} / z$ calcd for $\mathrm{C}_{25} \mathrm{H}_{21} \mathrm{~N}_{3} \mathrm{O}_{3} \mathrm{Na}[\mathrm{M}+\mathrm{Na}]^{+}$, 434.2; found, 434.5.

Ethyl 5-Phenylimidazo[1,5-a]quinoline-3-carboxylate (8a). This compound was prepared from $28^{61}(0.20 \mathrm{~g}, 0.834 \mathrm{mmol})$, ethyl isocyanoacetate $(0.28 \mathrm{~mL}, 2.56 \mathrm{mmol})$, and potassium tert-butoxide $(0.27 \mathrm{~g}, 2.41 \mathrm{mmol})$ according to the general procedure described for the synthesis of $7 \mathbf{a}-\mathbf{i}, \mathbf{k}-\mathbf{m}, \mathbf{o}-\mathbf{y}$ and purified by flash chromatography with ethyl acetate as the eluent to obtain $8 \mathrm{a}$ as a white solid $(0.24 \mathrm{~g}$, yield $\left.91 \%, \mathrm{mp} 244-245^{\circ} \mathrm{C}\right) .{ }^{1} \mathrm{H}$ NMR $\left(400 \mathrm{MHz}, \mathrm{CDCl}_{3}\right): \delta 1.43(\mathrm{t}$, $J=7.0,3 \mathrm{H}), 4.45(\mathrm{q}, J=7.0,2 \mathrm{H}), 7.36-7.54(\mathrm{~m}, 6 \mathrm{H}), 7.65(\mathrm{t}, J=7.6$, $1 \mathrm{H}), 7.77(\mathrm{~d}, J=8.1,1 \mathrm{H}), 8.02(\mathrm{~s}, 1 \mathrm{H}), 8.09(\mathrm{~d}, J=8.2,1 \mathrm{H}), 8.64(\mathrm{~s}$, 1H). ${ }^{13} \mathrm{C}$ NMR $\left(100 \mathrm{MHz}, \mathrm{CDCl}_{3}\right): \delta 14.6,60.5,115.1,117.2,123.9$, $124.6,126.1,127.8,128.1,128.3,128.6,129.6,130.7,132.4,138.1$, 138.4, 163.4. MS (ESI) $m / z$ calcd for $\mathrm{C}_{20} \mathrm{H}_{16} \mathrm{~N}_{2} \mathrm{O}_{2} \mathrm{Na}[\mathrm{M}+\mathrm{Na}]^{+}$, 339.1; found, 338.8.

tert-Butyl 5-Phenylimidazo[1,5-a]quinoline-3-carboxylate (8b). This compound was prepared from $28^{61}(1.0 \mathrm{~g}, 4.17 \mathrm{mmol})$, tertbutyl isocyanoacetate $(1.8 \mathrm{~mL}, 12.4 \mathrm{mmol})$, and potassium tertbutoxide (1.4 g, $12.5 \mathrm{mmol}$ ) according to the general procedure described for the synthesis of $7 \mathbf{a}-\mathbf{i}, \mathbf{k}-\mathbf{m}, \mathbf{o}-\mathbf{y}$ and purified by flash chromatography with $n$-hexane-ethyl acetate $(1: 1)$ as the eluent to obtain $8 \mathbf{b}$ as a white solid $\left(1.0 \mathrm{~g}\right.$, yield $\left.70 \%, \mathrm{mp} 231-233{ }^{\circ} \mathrm{C}\right) .{ }^{1} \mathrm{H}$ $\operatorname{NMR}\left(400 \mathrm{MHz}, \mathrm{CDCl}_{3}\right): \delta 1.66(\mathrm{~s}, 9 \mathrm{H}), 7.37-7.55(\mathrm{~m}, 6 \mathrm{H}), 7.67(\mathrm{t}$, $J=7.5,1 \mathrm{H}), 7.79(\mathrm{~d}, J=8.0,1 \mathrm{H}), 8.04(\mathrm{~s}, 1 \mathrm{H}), 8.11(\mathrm{~d}, J=8.1,1 \mathrm{H})$, $8.68(\mathrm{~s}, 1 \mathrm{H}) .{ }^{13} \mathrm{C}$ NMR $\left(100 \mathrm{MHz}, \mathrm{CDCl}_{3}\right): \delta 28.5,81.1,115.1,117.5$, $123.8,125.9,126.0,127.5,128.1,128.2,128.6,129.5,130.8,132.0$, 138.0, 138.2, 162.9. MS (ESI) $\mathrm{m} / z$ calcd for $\mathrm{C}_{22} \mathrm{H}_{20} \mathrm{~N}_{2} \mathrm{O}_{2} \mathrm{Na}[\mathrm{M}+$ $\mathrm{Na}]^{+}, 367.1$; found, 367.2.

$\mathrm{N}, \mathrm{N}$-Dimethyl-5-phenylimidazo[1,5-a]quinoline-3-carboxamide (8c). A mixture of acid $32(0.40 \mathrm{~g}, 1.39 \mathrm{mmol})$ in acetonitrile $(17 \mathrm{~mL})$ and water $(34 \mathrm{~mL})$ was treated with a $0.1 \mathrm{M}$ solution of sodium carbonate up to $\mathrm{pH} 7.5$ and then with a solution of 2,3,5,6terafluorophenol $(0.46 \mathrm{~g}, 2.77 \mathrm{mmol})$ in acetonitrile $(1.0 \mathrm{~mL})$ and EDC hydrochloride $(0.53 \mathrm{~g}, 2.76 \mathrm{mmol})$. The reaction mixture was stirred at room temperature for $4 \mathrm{~h}$, and the precipitate was collected by filtration and purified by flash chromatography to obtain the corresponding 2,3,5,6-terafluorophenyl ester as an off-white solid (0.34 g, yield $56 \%, \mathrm{mp} 243-245{ }^{\circ} \mathrm{C}$ ), which was promptly used in the subsequent step without any further purification. ${ }^{1} \mathrm{H}$ NMR $(200 \mathrm{MHz}$, $\left.\mathrm{CDCl}_{3}\right): \delta 6.91-7.08(\mathrm{~m}, 1 \mathrm{H}), 7.40-7.52(\mathrm{~m}, 6 \mathrm{H}), 7.67-7.82(\mathrm{~m}$ $2 \mathrm{H}), 7.98(\mathrm{~s}, 1 \mathrm{H}), 8.15(\mathrm{~d}, J=8.3,1 \mathrm{H}), 8.80(\mathrm{~s}, 1 \mathrm{H})$. MS (ESI): $\mathrm{m} / z$ $459\left(\mathrm{M}+\mathrm{Na}^{+}\right)$. To a solution of the 2,3,5,6-tetrafluorophenyl ester $(0.10 \mathrm{~g}, 0.229 \mathrm{mmol})$ in dry THF $(15 \mathrm{~mL})$, a $2 \mathrm{M}$ solution of dimethylamine in THF $(0.35 \mathrm{~mL}, 0.70 \mathrm{mmol})$ was added. The reaction mixture was stirred at room temperature for $1 \mathrm{~h}$ and then concentrated under reduced pressure. Purification of the residue by flash chromatography with ethyl acetate $-n$-hexane $(7: 3)$ as the eluent gave $8 \mathrm{c}$ as a white solid ( $52 \mathrm{mg}$, yield $\left.72 \%, \mathrm{mp} 235-236{ }^{\circ} \mathrm{C}\right) .{ }^{1} \mathrm{H}$ NMR (400 MHz, $\left.\mathrm{CDCl}_{3}\right): \delta 3.15$ (br s, $\left.3 \mathrm{H}\right), 3.57$ (br s, $\left.3 \mathrm{H}\right), 7.41-$ $7.49(\mathrm{~m}, 6 \mathrm{H}), 7.63(\mathrm{t}, J=7.7,1 \mathrm{H}), 7.77(\mathrm{~d}, J=8.2,1 \mathrm{H}), 8.04-8.11$ $(\mathrm{m}, 2 \mathrm{H}), 8.60$ (s, $1 \mathrm{H})$. MS (ESI) $\mathrm{m} / z$ calcd for $\mathrm{C}_{20} \mathrm{H}_{18} \mathrm{~N}_{3} \mathrm{O}[\mathrm{M}+\mathrm{H}]^{+}$, 316.1; found, 316.1. 
$N$-Benzyl-N-methyl-5-phenylimidazo[1,5-a]quinoline-3-carboxamide (8d). This compound was prepared by using the same procedure described for $8 \mathrm{c}$ (except that $\mathrm{N}$-methylbenzylamine was used instead of dimethylamine) and purified by flash chromatography with $n$ hexane-ethyl acetate $(1: 1)$ as the eluent to obtain $\mathbf{8 d}$ as a white solid (yield $48 \%$, mp $157-159^{\circ} \mathrm{C}$ ). Because the amide nitrogen of this compound bears two different substituents, its ${ }^{1} \mathrm{H}$ NMR spectrum shows the presence of a (ca. 54:46) mixture of two different rotamers in equilibrium; for the sake of simplification, the integral values have not been given. ${ }^{1} \mathrm{H}$ NMR $\left(400 \mathrm{MHz}, \mathrm{CDCl}_{3}\right): \delta 3.03$ (br s), 3.51 (br s), 4.81 (br s), 5.46 (br s), 7.28-7.54 (m), 7.63 (t, J=7.3), 7.79 (d, $J=$ 8.1), 8.06 (br s), 8.18 (br s), 8.58 (br s). MS (ESI) $\mathrm{m} / z$ calcd for $\mathrm{C}_{26} \mathrm{H}_{22} \mathrm{~N}_{3} \mathrm{O}[\mathrm{M}+\mathrm{H}]^{+}$, 392.2; found, 392.0.

tert-Butyl 4-Methyl-5-phenylimidazo[1,5-a]quinoline-3-carboxylate (8e). This compound was prepared from $29^{42}(1.0 \mathrm{~g}, 3.94 \mathrm{mmol})$, tert-butyl isocyanoacetate $(1.7 \mathrm{~mL}, 11.7 \mathrm{mmol})$, and potassium tertbutoxide $(1.3 \mathrm{~g}, 11.6 \mathrm{mmol})$ according to the general procedure described for the synthesis of $7 \mathbf{a}-\mathbf{i}, \mathbf{k}-\mathbf{m}, \mathbf{o}-\mathbf{y}$ and purified by flash chromatography with $n$-hexane-ethyl acetate $(1: 1)$ as the eluent to obtain $8 \mathrm{e}$ as a creamy solid $\left(0.30 \mathrm{~g}\right.$, yield $\left.21 \%, \mathrm{mp} 204-205{ }^{\circ} \mathrm{C}\right) .{ }^{1} \mathrm{H}$ $\operatorname{NMR}\left(400 \mathrm{MHz}, \mathrm{CDCl}_{3}\right): \delta 1.65(\mathrm{~s}, 9 \mathrm{H}), 2.43(\mathrm{~s}, 3 \mathrm{H}), 7.18(\mathrm{~d}, J=$ 8.1, $1 \mathrm{H}), 7.22-7.26(\mathrm{~m}, 2 \mathrm{H}), 7.27-7.35(\mathrm{~m}, 1 \mathrm{H}), 7.46-7.56(\mathrm{~m}, 4 \mathrm{H})$, $8.03(\mathrm{~d}, J=8.3,1 \mathrm{H}), 8.69(\mathrm{~s}, 1 \mathrm{H})$. MS (ESI) $\mathrm{m} / z$ calcd for $\mathrm{C}_{23} \mathrm{H}_{22} \mathrm{~N}_{2} \mathrm{O}_{2} \mathrm{Na}[\mathrm{M}+\mathrm{Na}]^{+}$, 381.2; found, 381.2.

$N$-Benzyl- $N$,4-dimethyl-5-phenylimidazo[1,5-a]quinoline-3-carboxamide (8f). This compound was prepared from acid 33 by using the same procedure described for $\mathbf{8 c}$ (except that $\mathrm{N}$-methylbenzylamine was used instead of dimethylamine) and purified by flash chromatography with ethyl acetate as the eluent to obtain $\mathbf{8 f}$ as a paleyellow glassy solid (yield 67\%). Because the amide nitrogen of this compound bears two different substituents, its ${ }^{1} \mathrm{H}$ NMR spectrum shows the presence of a (ca. 54:46) mixture of two different rotamers in equilibrium; for the sake of simplification, the integral values have not been given. ${ }^{1} \mathrm{H}$ NMR (400 MHz, $\mathrm{CDCl}_{3}$ ): $\delta 2.24$ (s), 3.01 (s), 3.08 (s), 4.72 (s), $4.82(\mathrm{~s}), 7.16-7.36(\mathrm{~m}), 7.39$ (d, $J=7.3), 7.42-7.57$ $(\mathrm{m}), 7.89-8.08(\mathrm{~m}), 8.70(\mathrm{~s}), 8.74(\mathrm{~s})$. MS (ESI) $\mathrm{m} / \mathrm{z}$ calcd for $\mathrm{C}_{27} \mathrm{H}_{24} \mathrm{~N}_{3} \mathrm{O}[\mathrm{M}+\mathrm{H}]^{+}$, 406.2; found, 406.3.

Diethyl 5-Phenylimidazo[1,5-a]quinoline-3,4-dicarboxylate (8g). This compound was prepared from $30^{62}(0.36 \mathrm{~g}, 1.15 \mathrm{mmol})$, ethyl isocyanoacetate $(0.38 \mathrm{~mL}, 3.48 \mathrm{mmol})$, and potassium tert-butoxide $(0.37 \mathrm{~g}, 3.30 \mathrm{mmol})$ according to the general procedure described for the synthesis of $7 \mathbf{a}-\mathbf{i}, \mathbf{k}-\mathbf{m}, \mathbf{o}-\mathbf{y}$ and purified by flash chromatography with ethyl acetate as the eluent to obtain $8 \mathrm{~g}$ as a white solid $(0.26 \mathrm{~g}$, yield $58 \%$, mp $\left.163-164{ }^{\circ} \mathrm{C}\right) .{ }^{1} \mathrm{H}$ NMR $\left(400 \mathrm{MHz}, \mathrm{CDCl}_{3}\right): \delta 0.97(\mathrm{t}$, $J=7.1,3 \mathrm{H}), 1.40(\mathrm{t}, J=7.1,3 \mathrm{H}), 4.12(\mathrm{q}, J=7.1,2 \mathrm{H}), 4.39(\mathrm{q}, J=7.1$, $2 \mathrm{H}), 7.29-7.40(\mathrm{~m}, 4 \mathrm{H}), 7.42-7.50(\mathrm{~m}, 3 \mathrm{H}), 7.62-7.68(\mathrm{~m}, 1 \mathrm{H})$, $8.08(\mathrm{~d}, J=8.4,1 \mathrm{H}), 8.72(\mathrm{~s}, 1 \mathrm{H}) .{ }^{13} \mathrm{C}$ NMR $\left(100 \mathrm{MHz}, \mathrm{CDCl}_{3}\right): \delta$ $13.6,14.5,60.7,61.4,114.7,123.3,124.2,125.6,126.4,127.7,128.2$, 128.5, 129.1, 130.0, 130.2, 130.4, 135.0, 136.3, 162.7, 165.3. MS (ESI) $m / z$ calcd for $\mathrm{C}_{23} \mathrm{H}_{20} \mathrm{~N}_{2} \mathrm{O}_{4} \mathrm{Na}[\mathrm{M}+\mathrm{Na}]^{+}$, 411.1; found, 410.8 .

Ethyl 4-(2-Ethoxy-2-oxoethyl)-5-phenylimidazo[1,5-a]quinoline3 -carboxylate $(8 h)$. This compound was prepared from $31^{42}(0.20$ $\mathrm{g}, 0.614 \mathrm{mmol})$, ethyl isocyanoacetate $(0.24 \mathrm{~mL}, 2.20 \mathrm{mmol})$, and potassium tert-butoxide $(0.20 \mathrm{~g}, 1.78 \mathrm{mmol})$ according to the general procedure described for the synthesis of $7 \mathbf{a}-\mathbf{i}, \mathbf{k}-\mathbf{m}, \mathbf{o}-\mathbf{y}$ and purified by flash chromatography with ethyl acetate as the eluent to obtain $\mathbf{8 h}$ as a white solid $\left(0.14 \mathrm{~g}\right.$, yield $\left.57 \%, \mathrm{mp} 186-187^{\circ} \mathrm{C}\right) .{ }^{1} \mathrm{H}$ NMR $(400$ $\left.\mathrm{MHz}, \mathrm{CDCl}_{3}\right): \delta 1.18(\mathrm{t}, J=7.1,3 \mathrm{H}), 1.43(\mathrm{t}, J=7.1,3 \mathrm{H}), 4.10(\mathrm{q}, J=$ $7.1,2 \mathrm{H}), 4.15(\mathrm{~s}, 2 \mathrm{H}), 4.40(\mathrm{q}, J=7.1,2 \mathrm{H}), 7.19(\mathrm{~d}, J=8.2,1 \mathrm{H})$, $7.22-7.27(\mathrm{~m}, 2 \mathrm{H}), 7.34(\mathrm{t}, J=7.7,1 \mathrm{H}), 7.44-7.51(\mathrm{~m}, 3 \mathrm{H}), 7.61(\mathrm{t}, J$ $=7.8,1 \mathrm{H}), 8.08(\mathrm{~d}, J=8.3,1 \mathrm{H}), 8.73(\mathrm{~s}, 1 \mathrm{H})$. MS $(\mathrm{ESI}) \mathrm{m} / z$ calcd for $\mathrm{C}_{24} \mathrm{H}_{22} \mathrm{~N}_{2} \mathrm{O}_{4} \mathrm{Na}[\mathrm{M}+\mathrm{Na}]^{+}$, 425.2; found, 424.8 .

Ethyl 4-Hydroxymethyl-5-phenylimidazo[1,5-a]quinoline-3-carboxylate (8i). To a solution of $36(1.0 \mathrm{~g}, 2.17 \mathrm{mmol})$ in THF (40 $\mathrm{mL})$ cooled at $0-5{ }^{\circ} \mathrm{C}$, a solution $\left(1 \mathrm{M}\right.$ in THF) of $\mathrm{Bu}_{4} \mathrm{NF}(4.3 \mathrm{~mL}$, $4.3 \mathrm{mmol}$ ) was added. The reaction mixture was stirred at the same temperature for $30 \mathrm{~min}$ and overnight at room temperature, then diluted with water, and extracted with diethyl ether. The organic layer was washed with brine, dried over sodium sulfate, and concentrated under reduced pressure. Purification of the residue by flash chromatography with ethyl acetate as the eluent gave $8 \mathbf{i}$ as a white solid (0.20 g, yield $\left.27 \%, \mathrm{mp} 192-193{ }^{\circ} \mathrm{C}\right) .{ }^{1} \mathrm{H}$ NMR (400 MHz, $\left.\mathrm{CDCl}_{3}\right): \delta 1.49(\mathrm{t}, J=7.1,3 \mathrm{H}), 4.51(\mathrm{q}, J=7.1,2 \mathrm{H}), 4.64(\mathrm{~s}, 2 \mathrm{H})$, $5.13($ br s, $1 \mathrm{H}), 7.32(\mathrm{~d}, J=8.1,1 \mathrm{H}), 7.35-7.41(\mathrm{~m}, 3 \mathrm{H}), 7.45-7.56$ $(\mathrm{m}, 3 \mathrm{H}), 7.64(\mathrm{t}, J=7.7,1 \mathrm{H}), 8.09(\mathrm{~d}, J=8.3,1 \mathrm{H}), 8.78(\mathrm{~s}, 1 \mathrm{H})$. MS (ESI) $\mathrm{m} / z$ calcd for $\mathrm{C}_{21} \mathrm{H}_{18} \mathrm{~N}_{2} \mathrm{O}_{3} \mathrm{Na}[\mathrm{M}+\mathrm{Na}]^{+}, 369.1$; found, 368.8 .

Ethyl 10,11-Dihydro-9H-cyclopenta[c]imidazo[1,5-a]quinoline-1carboxylate (9). This compound was prepared from $37^{43}(0.16 \mathrm{~g}$, $0.786 \mathrm{mmol})$, ethyl isocyanoacetate $(0.26 \mathrm{~mL}, 2.38 \mathrm{mmol})$, and potassium tert-butoxide $(0.25 \mathrm{~g}, 2.23 \mathrm{mmol})$ according to the general procedure described for the synthesis of $7 \mathbf{a}-\mathbf{i}, \mathbf{k}-\mathbf{m}, \mathbf{o}-\mathbf{y}$ and purified by flash chromatography with ethyl acetate as the eluent to obtain 9 as an off-white solid $\left(0.15 \mathrm{~g}\right.$, yield $68 \%$, mp $\left.200-201{ }^{\circ} \mathrm{C}\right) .{ }^{1} \mathrm{H}$ NMR $(400$ $\left.\mathrm{MHz}, \mathrm{CDCl}_{3}\right): \delta 1.46(\mathrm{t}, J=7.1,3 \mathrm{H}), 2.20-2.33(\mathrm{~m}, 2 \mathrm{H}), 3.14(\mathrm{t}, J=$ $7.6,2 \mathrm{H}), 3.59(\mathrm{t}, J=7.4,2 \mathrm{H}), 4.44(\mathrm{q}, J=7.1,2 \mathrm{H}), 7.50(\mathrm{t}, J=7.5$, $1 \mathrm{H}), 7.59(\mathrm{t}, J=7.7,1 \mathrm{H}), 7.70(\mathrm{~d}, J=7.8,1 \mathrm{H}), 8.02(\mathrm{~d}, J=8.3,1 \mathrm{H})$, $8.61(\mathrm{~s}, 1 \mathrm{H})$. MS (ESI) $\mathrm{m} / z$ calcd for $\mathrm{C}_{17} \mathrm{H}_{17} \mathrm{~N}_{2} \mathrm{O}_{2}[\mathrm{M}+\mathrm{H}]^{+}, 281.1$; found, 280.9 .

General Procedure for the Synthesis of Target Imidazo[1,5a]quinoxaline Derivatives $10 a-d$. A solution of the suitable 4-acetyl3,4-dihydroquinoxalin-2 $(1 H)$-one derivative $(38$ or 39$)$ in dry THF was cooled at $0{ }^{\circ} \mathrm{C}$ for $10 \mathrm{~min}$ under argon and then treated with potassium tert-butoxide. The resulting mixture was allowed to warm at room temperature and stirred for 45 min under argon atmosphere. Then, it was cooled to $-55{ }^{\circ} \mathrm{C}$, diethyl chlorophosphate was added, and the resulting mixture was stirred at $-55^{\circ} \mathrm{C}$ for $15 \mathrm{~min}$ and finally at room temperature for $45 \mathrm{~min}$. The reaction mixture was cooled again at $-55^{\circ} \mathrm{C}$ and then treated with the suitable isocyanoacetate and potassium tert-butoxide. The resulting mixture was allowed to stir at $-55{ }^{\circ} \mathrm{C}$ for $2 \mathrm{~h}$ and finally at room temperature for $30 \mathrm{~min}$. Then, glacial acetic acid was added and the reaction mixture was concentrated under reduced pressure. The residue was dissolved into $\mathrm{CHCl}_{3}$ and washed with water and with brine. The organic layer was dried over sodium sulfate and concentrated under reduced pressure. Purification of the residue by flash chromatography with the appropriate eluent gave the expected target derivative $(10 a-d)$.

Ethyl 5-Acetyl-4,5-dihydroimidazo[1,5-a]quinoxaline-3-carboxylate (10a). This compound was prepared from $38^{31}(2.0 \mathrm{~g}, 10.5$ $\mathrm{mmol})$, potassium tert-butoxide $(1.3 \mathrm{~g}, 11.6 \mathrm{mmol})$, diethyl chlorophosphate $(1.68 \mathrm{~mL}, 11.6 \mathrm{mmol})$, ethyl isocyanoacetate $(1.8$ $\mathrm{mL}, 16.5 \mathrm{mmol})$, and potassium tert-butoxide $(1.3 \mathrm{~g}, 11.6 \mathrm{mmol})$ according to the above general procedure and purified by flash chromatography with ethyl acetate as the eluent to obtain 10a as an off-white crystalline solid (1.22 g, yield $41 \%)$. An analytical sample was obtained by recrystallization from ethyl acetate (colorless prisms, $\mathrm{mp}$ $\left.173-174{ }^{\circ} \mathrm{C}\right) .{ }^{1} \mathrm{H}$ NMR $\left(400 \mathrm{MHz}, \mathrm{CDCl}_{3}\right): \delta 1.39(\mathrm{t}, J=7.1,3 \mathrm{H})$, $2.25(\mathrm{~s}, 3 \mathrm{H}), 4.37(\mathrm{q}, J=7.1,2 \mathrm{H}), 5.24(\mathrm{~s}, 2 \mathrm{H}), 7.30-7.59(\mathrm{~m}, 4 \mathrm{H})$, $8.02(\mathrm{~s}, 1 \mathrm{H})$. MS (ESI) $\mathrm{m} / z$ calcd for $\mathrm{C}_{15} \mathrm{H}_{15} \mathrm{~N}_{3} \mathrm{O}_{3} \mathrm{Na}[\mathrm{M}+\mathrm{Na}]^{+}$, 308.1; found, 307.9.

tert-Butyl 5-Acetyl-4,5-dihydroimidazo[1,5-a]quinoxaline-3-carboxylate (10b). This compound was prepared from $38^{31}(1.0 \mathrm{~g}$, $5.25 \mathrm{mmol})$, potassium tert-butoxide $(0.65 \mathrm{~g}, 5.79 \mathrm{mmol})$, diethyl chlorophosphate $(0.84 \mathrm{~mL}, 5.81 \mathrm{mmol})$, tert-butyl isocyanoacetate $(0.92 \mathrm{~mL}, 6.32 \mathrm{mmol})$, and potassium tert-butoxide $(0.65 \mathrm{~g}, 5.78$ $\mathrm{mmol}$ ) according to the above general procedure and purified by flash chromatography with ethyl acetate as the eluent to obtain $\mathbf{1 0 b}$ as a white solid ( $0.69 \mathrm{~g}$, yield $42 \%)$. An analytical sample was obtained by recrystallization from ethyl acetate (colorless crystals, mp $184-185^{\circ} \mathrm{C}$, lit. $\left.^{23} 150-152{ }^{\circ} \mathrm{C}\right) .{ }^{1} \mathrm{H}$ NMR $\left(400 \mathrm{MHz}, \mathrm{CDCl}_{3}\right): \delta 1.63(\mathrm{~s}, 9 \mathrm{H}), 2.28$ (br s, 3H), 5.26 (br s, 2H), 7.29-7.59 (m, 4H), 8.01 (s, 1H). MS (ESI) $\mathrm{m} / z$ calcd for $\mathrm{C}_{17} \mathrm{H}_{19} \mathrm{~N}_{3} \mathrm{O}_{3} \mathrm{Na}[\mathrm{M}+\mathrm{Na}]^{+}$, 336.1; found, 335.8.

Ethyl 5-Acetyl-7-fluoro-4,5-dihydroimidazo[1,5-a]quinoxaline-3carboxylate (10c). This compound was prepared from 39 (150 mg, $0.72 \mathrm{mmol})$, potassium tert-butoxide $(87 \mathrm{mg}, 0.78 \mathrm{mmol})$, diethyl chlorophosphate $(0.11 \mathrm{~mL}, 0.76 \mathrm{mmol})$, ethyl isocyanoacetate $(0.12$ $\mathrm{mL}, 1.1 \mathrm{mmol})$, and potassium tert-butoxide $(87 \mathrm{mg}, 0.78 \mathrm{mmol})$ according to the above general procedure and purified by flash chromatography with ethyl acetate as the eluent to obtain $10 \mathrm{c}$ as a light-brown solid (70 $\mathrm{mg}$, yield $32 \%$ ). An analytical sample was obtained by recrystallization from cyclohexane-ethyl acetate (colorless 
crystals, mp $\left.149-150{ }^{\circ} \mathrm{C}\right) .{ }^{1} \mathrm{H}$ NMR $\left(400 \mathrm{MHz}, \mathrm{CDCl}_{3}\right): \delta 1.42(\mathrm{t}, J=$ 7.1, 3H), $2.33(\mathrm{~s}, 3 \mathrm{H}), 4.41(\mathrm{q}, J=7.1,2 \mathrm{H}), 5.25(\mathrm{~s}, 2 \mathrm{H}), 7.02-7.12$ (m, 1H), 7.41 (br s, 1H), 7.49-7.59 (m, 1H), 7.99 (s, 1H). MS (ESI) $\mathrm{m} / z$ calcd for $\mathrm{C}_{15} \mathrm{H}_{14} \mathrm{FN}_{3} \mathrm{O}_{3} \mathrm{Na}[\mathrm{M}+\mathrm{Na}]^{+}$, 326.1; found, 325.8.

tert-Butyl 5-Acetyl-7-fluoro-4,5-dihydroimidazo[1,5-a]quinoxaline-3-carboxylate (10d). This compound was prepared from $39(60 \mathrm{mg}, 0.29 \mathrm{mmol})$, potassium tert-butoxide $(37 \mathrm{mg}, 0.33$ $\mathrm{mmol})$, diethyl chlorophosphate $(0.048 \mathrm{~mL}, 0.33 \mathrm{mmol})$, tert-butyl isocyanoacetate $(0.067 \mathrm{~mL}, 0.46 \mathrm{mmol})$, and potassium tert-butoxide ( $37 \mathrm{mg}, 0.33 \mathrm{mmol}$ ) according to the above general procedure and purified by flash chromatography with ethyl acetate as the eluent to obtain 10d as a light-brown solid (30 mg, yield $31 \%$ ). An analytical sample was obtained by recrystallization from ethyl acetate (colorless crystals, mp 208-209 $\left.{ }^{\circ} \mathrm{C}\right) .{ }^{1} \mathrm{H}$ NMR $\left(400 \mathrm{MHz}, \mathrm{CDCl}_{3}\right): \delta 1.62(\mathrm{~s}$, $9 \mathrm{H}), 2.34(\mathrm{~s}, 3 \mathrm{H}), 5.23(\mathrm{~s}, 2 \mathrm{H}), 7.03-7.11(\mathrm{~m}, 1 \mathrm{H}), 7.39(\mathrm{br} \mathrm{s}, 1 \mathrm{H})$, $7.46-7.55(\mathrm{~m}, 1 \mathrm{H}), 7.96(\mathrm{~s}, 1 \mathrm{H})$. MS (ESI) $\mathrm{m} / \mathrm{z}$ calcd for $\mathrm{C}_{17} \mathrm{H}_{18} \mathrm{FN}_{3} \mathrm{O}_{3} \mathrm{Na}[\mathrm{M}+\mathrm{Na}]^{+}$, 354.1; found, 353.8.

2-Chloro- $\mathrm{N}, \mathrm{N}$-dimethylquinoline-4-carboxamide (11). This compound was prepared from of 2-hydroxy-4-quinolinecarboxylic acid and dimethylamine by following the procedure described in ref 38 and was purified by flash chromatography with $n$-hexane-ethyl acetate $(1: 1)$ as the eluent (yield 39\%). ${ }^{1} \mathrm{H}$ NMR $\left(200 \mathrm{MHz}, \mathrm{CDCl}_{3}\right): \delta 2.84(\mathrm{~s}, 3 \mathrm{H})$, $3.25(\mathrm{~s}, 3 \mathrm{H}), 7.31(\mathrm{~s}, 1 \mathrm{H}), 7.55-7.62(\mathrm{~m}, 1 \mathrm{H}), 7.73-7.80(\mathrm{~m}, 2 \mathrm{H})$, $8.06($ d. $J=8.3,1 \mathrm{H})$. MS (ESI) $\mathrm{m} / z$ calcd for $\mathrm{C}_{12} \mathrm{H}_{11} \mathrm{ClN}_{2} \mathrm{ONa}[\mathrm{M}+$ $\mathrm{Na}]^{+}, 257.0$; found, 257.2.

$\mathrm{N}$-Butyl-2-chloro-N-methylquinoline-4-carboxamide (12). This compound was prepared from of 2-hydroxy-4-quinolinecarboxylic acid and $\mathrm{N}$-methylbutylamine by following the procedure described in ref 38 and was purified by flash chromatography with $n$-hexane-ethyl acetate $(9: 1)$ as the eluent (yield $81 \%, \mathrm{mp} 86-87^{\circ} \mathrm{C}$ ). Because the amide nitrogen of this compound bears two different substituents, its ${ }^{1} \mathrm{H}$ NMR spectrum shows the presence of two different rotamers in equilibrium; for the sake of simplification, the integral intensities have not been given. ${ }^{1} \mathrm{H}$ NMR $\left(200 \mathrm{MHz}, \mathrm{CDCl}_{3}\right): \delta 0.70(\mathrm{t}, J=7.2)$, 0.98-1.17 (m), 1.37-1.55 (m), 1.65-1.79 (m), $2.78(\mathrm{~s}), 3.04(\mathrm{t}, J=$ 7.5), $3.19(\mathrm{~s}), 3.64(\mathrm{t}, J=7.5), 7.28(\mathrm{~s}), 7.53-7.61(\mathrm{~m}), 7.71-7.78$ (m), 8.04 (d. $J=8.2$ ). MS (ESI) $m / z$ calcd for $\mathrm{C}_{15} \mathrm{H}_{18} \mathrm{ClN}_{2} \mathrm{O}[\mathrm{M}+$ $\mathrm{H}]^{+}$, 277.1; found, 277.5.

tert-Butyl 2-Chloro-3-methylquinoline-4-carboxylate (16). A solution of acid chloride $25^{38}$ (3.5 g, $14.6 \mathrm{mmol}$ ) in dry THF (15 $\mathrm{mL}$ ) was cooled at $0-5{ }^{\circ} \mathrm{C}$, and a mixture of potassium tert-butoxide $(1.64 \mathrm{~g}, 14.6 \mathrm{mmol})$ in $15 \mathrm{~mL}$ of dry THF was added. The resulting mixture was stirred at the same temperature for $10 \mathrm{~min}$ and at room temperature for $30 \mathrm{~min}$. The reaction mixture was then poured onto crushed ice, and the precipitate was collected by filtration, dried under reduced pressure, and purified by flash chromatography with petroleum ether-ethyl acetate $(9: 1)$ as the eluent to obtain $\mathbf{1 6}$ as a white solid (3.4 g, yield $84 \%$ ). An analytical sample was obtained by recrystallization from $n$-hexane (mp $\left.107-108{ }^{\circ} \mathrm{C}\right) .{ }^{1} \mathrm{H}$ NMR (400 $\left.\mathrm{MHz}, \mathrm{CDCl}_{3}\right): \delta 1.69(\mathrm{~s}, 9 \mathrm{H}), 2.52(\mathrm{~s}, 3 \mathrm{H}), 7.56(\mathrm{t}, J=7.6,1 \mathrm{H})$; 7.67-7.74 (m, 2H), $7.99(\mathrm{~d}, J=8.4,1 \mathrm{H})$. MS (ESI) $\mathrm{m} / z$ calcd for $\mathrm{C}_{15} \mathrm{H}_{17} \mathrm{ClNO}_{2}[\mathrm{M}+\mathrm{H}]^{+}$, 278.1; found, 278.0.

2-Chloro- $N, N$-dipropylquinoline-6-fluoro-4-carboxamide (22). A mixture of acid $27 \mathrm{a}(1.0 \mathrm{~g}, 4.43 \mathrm{mmol})$ in thionyl chloride $(5.0 \mathrm{~mL})$ was refluxed under argon for $2 \mathrm{~h}$. The thionyl chloride excess was then removed under reduced pressure, and the resulting acid chloride was immediately used without further purification. To a mixture of acid chloride in $20 \mathrm{~mL}$ of dichloromethane cooled at $0-5{ }^{\circ} \mathrm{C}$, dipropylamine $(0.57 \mathrm{~mL}, 4.16 \mathrm{mmol})$ and triethylamine (TEA, 1.0 $\mathrm{mL}$ ) were added and the resulting mixture was stirred at room temperature for $30 \mathrm{~min}$ while the reaction progress was monitored by TLC. The reaction mixture was concentrated under reduced pressure and partitioned between $\mathrm{CH}_{2} \mathrm{Cl}_{2}$ and water. The organic layer was dried over sodium sulfate and concentrated under reduced pressure. The resulting residue was purified by flash chromatography with $n$ hexane-ethyl acetate (8:2) as the eluent to obtain $\mathbf{2 2}$ as pale-yellow oil, which slowly crystallized on standing ( $1.1 \mathrm{~g}$, yield $86 \%) .{ }^{1} \mathrm{H}$ NMR $\left(200 \mathrm{MHz}, \mathrm{CDCl}_{3}\right): \delta 0.67(\mathrm{t}, J=7.3,3 \mathrm{H}), 1.02(\mathrm{t}, J=7.3,3 \mathrm{H}), 1.37-$ $1.56(\mathrm{~m}, 2 \mathrm{H}), 1.67-1.86(\mathrm{~m}, 2 \mathrm{H}), 2.99(\mathrm{t}, J=7.3,2 \mathrm{H}), 3.54(\mathrm{br} \mathrm{s}$,
$2 \mathrm{H}), 7.26-7.37(\mathrm{~m}, 2 \mathrm{H}), 7.45-7.55(\mathrm{~m}, 1 \mathrm{H}), 7.98-8.05(\mathrm{~m}, 1 \mathrm{H}) . \mathrm{MS}$ (ESI) $\mathrm{m} / z$ calcd for $\mathrm{C}_{16} \mathrm{H}_{19} \mathrm{ClFN}_{2} \mathrm{O}[\mathrm{M}+\mathrm{H}]^{+}$, 309.1; found, 309.6.

$\mathrm{N}$-Benzyl-2-chloro-6-fluoro- $\mathrm{N}$-methylquinoline-4-carboxamide (23). A mixture of acid $27 \mathrm{a}(1.0 \mathrm{~g}, 4.43 \mathrm{mmol})$ in thionyl chloride (5.0 $\mathrm{mL}$ ) was refluxed under argon for $2 \mathrm{~h}$. The thionyl chloride excess was then removed under reduced pressure, and the resulting acid chloride was immediately used without further purification. To a mixture of acid chloride in $20 \mathrm{~mL}$ of dichloromethane cooled at $0-5{ }^{\circ} \mathrm{C}, \mathrm{N}$ methylbenzylamine $(0.53 \mathrm{~mL}, 4.11 \mathrm{mmol})$ and TEA $(1.0 \mathrm{~mL})$ were added and the resulting mixture was stirred at room temperature for $30 \mathrm{~min}$ while the reaction progress was monitored by TLC. The reaction mixture was concentrated under reduced pressure and partitioned between $\mathrm{CH}_{2} \mathrm{Cl}_{2}$ and water. The organic layer was dried over sodium sulfate and concentrated under reduced pressure. The resulting residue was purified by flash chromatography with $n$-hexaneethyl acetate (7:3) as the eluent to obtain $\mathbf{2 3}$ as pale-yellow oil, which slowly crystallized on standing $\left(1.1 \mathrm{~g}\right.$, yield $\left.81 \%, \mathrm{mp} 97-98{ }^{\circ} \mathrm{C}\right)$. Because the amide nitrogen of this compound bears two different substituents, its ${ }^{1} \mathrm{H}$ NMR spectrum shows the presence of two different rotamers in equilibrium; for the sake of simplification, the integral intensities have not been given. ${ }^{1} \mathrm{H} \mathrm{NMR}\left(200 \mathrm{MHz}, \mathrm{CDCl}_{3}\right)$ : $\delta 2.69(\mathrm{~s}), 3.12(\mathrm{~s}), 4.28(\mathrm{~s}), 4.80(\mathrm{~s}), 6.98-7.01(\mathrm{~m}), 7.23-7.50(\mathrm{~m})$, 7.94-8.01 (m). MS (ESI) $m / z$ calcd for $\mathrm{C}_{18} \mathrm{H}_{15} \mathrm{ClFN}_{2} \mathrm{O}[\mathrm{M}+\mathrm{H}]^{+}$, 329.1; found, 329.3.

$\mathrm{N}$-Benzyl-6-bromo-2-chloro- $\mathrm{N}$-methylquinoline-4-carboxamide (24). A mixture of acid $27 \mathrm{~b}(1.3 \mathrm{~g}, 4.54 \mathrm{mmol})$ in dichloromethane (20 $\mathrm{mL}$ ) and thionyl chloride $(5.0 \mathrm{~mL})$ was refluxed under argon for $3 \mathrm{~h}$. The volatile was then removed under reduced pressure, and the resulting acid chloride was immediately used without further purification. To a mixture of acid chloride in $20 \mathrm{~mL}$ of dichloromethane cooled at $0-5{ }^{\circ} \mathrm{C}, \mathrm{N}$-methylbenzylamine $(1.2 \mathrm{~mL}, 9.3 \mathrm{mmol})$ and TEA $(1.0 \mathrm{~mL})$ were added, and the resulting mixture was stirred at room temperature for $30 \mathrm{~min}$ while the reaction progress was monitored by TLC. The reaction mixture was washed with water, dried over sodium sulfate, and concentrated under reduced pressure. The resulting residue was purified by flash chromatography with $n$ hexane-ethyl acetate (7:3) as the eluent to obtain 24 as a white solid $\left(1.0 \mathrm{~g}\right.$, yield $\left.57 \%, \mathrm{mp} 127-128^{\circ} \mathrm{C}\right)$. Because the amide nitrogen of this compound bears two different substituents, its ${ }^{1} \mathrm{H}$ NMR spectrum shows the presence of two different rotamers in equilibrium; for the sake of simplification, the integral values have not been given. ${ }^{1} \mathrm{H}$ NMR (200 MHz, $\left.\mathrm{CDCl}_{3}\right): \delta 2.73(\mathrm{~s}), 3.19$ (s), 4.31 (s), $4.86(\mathrm{~s})$, 7.02-7.06 (m), 7.29-7.45 (m), 7.78-7.97 (m). MS (ESI) $\mathrm{m} / z$ calcd for $\mathrm{C}_{18} \mathrm{H}_{15} \mathrm{BrClN}_{2} \mathrm{O}[\mathrm{M}+\mathrm{H}]^{+}$, 389.0; found, 389.4.

2-Chloro-6-fluoro-4-quinolinecarboxylic Acid (27a). A mixture of 6-fluoro-2-hydroxy-4-quinolinecarboxylic acid $\left(26 a^{41} 3.0 \mathrm{~g}, 14.5\right.$ $\mathrm{mmol}$ ) in $15 \mathrm{~mL}$ of $\mathrm{POCl}_{3}$ was heated to reflux for $2 \mathrm{~h}$ and then poured onto crushed ice. The precipitate was extracted with chloroform, and the organic layer was dried over sodium sulfate and concentrated under reduced pressure. Purification of the residue by washing with $n$-hexane gave acid 27 a $(2.3 \mathrm{~g}$, yield $70 \%)$, which was promptly used in the subsequent step. ${ }^{1} \mathrm{H}$ NMR $(200 \mathrm{MHz}$, DMSO$\left.d_{6}\right): \delta 7.75-7.85(\mathrm{~m}, 1 \mathrm{H}), 7.97(\mathrm{~s}, 1 \mathrm{H}), 8.06-8.14(\mathrm{~m}, 1 \mathrm{H}), 8.39-$ $8.46(\mathrm{~m}, 1 \mathrm{H}), 14.20(\mathrm{br} \mathrm{s}, 1 \mathrm{H})$.

6-Bromo-2-chloro-4-quinolinecarboxylic Acid (27b). A mixture of 6-bromo-2-hydroxy-4-quinolinecarboxylic acid (26b) (1.0 g, 3.7 mmol) in $10 \mathrm{~mL}$ of $\mathrm{POCl}_{3}$ was heated to reflux for $3 \mathrm{~h}$ and then poured onto crushed ice. The precipitate was extracted with ethyl acetate, and the organic layer was dried over sodium sulfated and concentrated under reduced pressure. Purification of the residue by washing with $n$-hexane gave acid $27 \mathrm{~b}$ (1.0 g, yield $94 \%)$, which was promptly used in the subsequent step. ${ }^{1} \mathrm{H}$ NMR $(200 \mathrm{MHz}$, DMSO$\left.d_{6}\right): \delta 7.95(\mathrm{~m}, 3 \mathrm{H}), 8.89(\mathrm{~s}, 1 \mathrm{H})$. MS (ESI, negative ions) $\mathrm{m} / \mathrm{z}$ calcd for $\mathrm{C}_{10} \mathrm{H}_{4} \mathrm{BrClNO}_{2}\left[\mathrm{M}-\mathrm{H}^{+}\right]^{-}$, 283.9; found, 284.1.

5-Phenylimidazo[1,5-a]quinoline-3-carboxylic Acid (32). A mixture of $8 \mathbf{b}(1.0 \mathrm{~g}, 2.90 \mathrm{mmol})$ in formic acid $(10 \mathrm{~mL})$ was stirred at room temperature overnight and then concentrated under reduced pressure to obtain acid 32 as an off-white solid $(0.75 \mathrm{~g}$, yield $90 \%$, mp 264-265 $\left.{ }^{\circ} \mathrm{C}\right) .{ }^{1} \mathrm{H}$ NMR (200 MHz, DMSO- $\left.d_{6}\right): \delta 7.45-7.81(\mathrm{~m}$, 
$9 \mathrm{H}), 8.58(\mathrm{~d}, J=8.2,1 \mathrm{H}), 9.25(\mathrm{~s}, 1 \mathrm{H}) 12.59(\mathrm{br} \mathrm{s}, 1 \mathrm{H})$. MS (ESI) $\mathrm{m} /$ $z$ calcd for $\mathrm{C}_{18} \mathrm{H}_{13} \mathrm{~N}_{2} \mathrm{O}_{2}[\mathrm{M}+\mathrm{H}]^{+}$, 289.1; found, 289.2 .

4-Methyl-5-phenylimidazo[1,5-a]quinoline-3-carboxylic Acid (33). A mixture of $8 \mathbf{e}(0.20 \mathrm{~g}, 0.558 \mathrm{mmol})$ in formic acid $(10 \mathrm{~mL})$ was stirred at room temperature overnight and then concentrated under reduced pressure to obtain acid 33 ( $0.15 \mathrm{~g}$, yield 89\%), which was used in the subsequent step without further purification.

2-Chloro-3-hydroxymethyl-4-phenylquinoline (34). To a $1 \mathrm{M}$ solution of lithium aluminum hydride (LAH, $20 \mathrm{~mL}, 20 \mathrm{mmol})$ cooled at $0-5{ }^{\circ} \mathrm{C}$, a solution of $30^{62}(3.0 \mathrm{~g}, 9.62 \mathrm{mmol})$ in THF $(40 \mathrm{~mL})$ was added and the resulting mixture was stirred at the same temperature for $15 \mathrm{~min}$. The LAH excess was then decomposed with water, and the reaction mixture was filtered and concentrated under reduced pressure. The residue was partitioned between dichloromethane and water, and the organic layer was washed with brine, dried over sodium sulfate, and concentrated under reduced pressure. Purification of the residue by flash chromatography with $n$-hexane-ethyl acetate $(1: 1)$ as the eluent afforded 34 (1.21 g, yield 47\%), which was used in the subsequent step without further purification. ${ }^{1} \mathrm{H}$ NMR $\left(200 \mathrm{MHz}, \mathrm{CDCl}_{3}\right): \delta 2.30(\mathrm{t}, J$ $=6.6,1 \mathrm{H}), 4.64(\mathrm{~d}, J=6.2,2 \mathrm{H}), 7.29-7.75(\mathrm{~m}, 8 \mathrm{H}), 8.02(\mathrm{~d}, J=8.3$, $1 \mathrm{H})$.

3-[(tert-Butyldimethylsilyloxy)methyl]-2-chloro-4-phenylquinoline (35). To a solution of $34(1.2 \mathrm{~g}, 4.45 \mathrm{mmol})$ in dichloromethane $(40 \mathrm{~mL})$ containing imidazole $(0.385 \mathrm{~g}, 5.66 \mathrm{mmol})$ and cooled at $0-$ $5{ }^{\circ} \mathrm{C}$, tert-butyldimethylsilyl chloride $(0.77 \mathrm{~g}, 5.1 \mathrm{mmol})$ was added. The resulting mixture was stirred at the same temperature for $15 \mathrm{~min}$ and then at room temperature for $2.5 \mathrm{~h}$. The reaction mixture was partitioned between dichloromethane and water, and the organic layer was washed with brine, dried over sodium sulfate, and concentrated under reduced pressure to afford 35 ( $1.4 \mathrm{~g}$, yield $82 \%)$, which was used in the subsequent step without further purification. ${ }^{1} \mathrm{H}$ NMR $(200$ $\left.\mathrm{MHz}, \mathrm{CDCl}_{3}\right): \delta 0.00(\mathrm{~s}, 6 \mathrm{H}), 0.85(\mathrm{~s}, 9 \mathrm{H}), 4.59(\mathrm{~s}, 2 \mathrm{H}), 7.32-7.72$ $(\mathrm{m}, 8 \mathrm{H}), 8.02(\mathrm{~d}, J=8.4,1 \mathrm{H})$. MS (ESI) $\mathrm{m} / z$ calcd for $\mathrm{C}_{22} \mathrm{H}_{27} \mathrm{ClNOSi}$ $[\mathrm{M}+\mathrm{H}]^{+}$, 384.2; found, 384.0.

Ethyl 4-[(tert-Butyldimethylsilyloxy)methyl]-5-phenylimidazo[1,5a]quinoline-3-carboxylate (36). This compound was prepared from $35(1.38 \mathrm{~g}, 3.59 \mathrm{mmol})$, ethyl isocyanoacetate $(1.3 \mathrm{~mL}, 11.9 \mathrm{mmol})$, and potassium tert-butoxide $(1.2 \mathrm{~g}, 10.7 \mathrm{mmol})$ according to the general procedure for the synthesis of $7 \mathbf{a}-\mathbf{i}, \mathbf{k}-\mathbf{m}, \mathbf{o}-\mathbf{y}$ to obtain pure 36 as a brown solid (1.35 g, yield $82 \%$ ), which was used in the subsequent step without further purification. ${ }^{1} \mathrm{H}$ NMR $(200 \mathrm{MHz}$, $\left.\mathrm{CDCl}_{3}\right): \delta-0.17(\mathrm{~s}, 6 \mathrm{H}), 0.71(\mathrm{~s}, 9 \mathrm{H}), 1.45(\mathrm{t}, J=7.0,3 \mathrm{H}), 4.43(\mathrm{q}, J$ $=7.0,2 \mathrm{H}), 5.00(\mathrm{~s}, 2 \mathrm{H}), 7.23-7.63(\mathrm{~m}, 8 \mathrm{H}), 8.06(\mathrm{~d}, J=8.2,1 \mathrm{H})$, $8.70(\mathrm{~s}, 1 \mathrm{H})$. MS (ESI) $m / z$ calcd for $\mathrm{C}_{27} \mathrm{H}_{33} \mathrm{~N}_{2} \mathrm{O}_{3} \mathrm{Si}[\mathrm{M}+\mathrm{H}]^{+}, 461.2$; found, 460.8 .

X-ray Crystallography. Single crystals of compounds $7 \mathbf{p}, \mathbf{s , t}$ and $10 a-c$ were submitted to X-ray data collection on an OxfordDiffraction Xcalibur Sapphire 3 diffractometer with a graphite monochromated Mo $\mathrm{K} \alpha$ radiation $(\lambda=0.71073 \AA)$ at $293 \mathrm{~K}$. The structures were solved by direct methods implemented in SHELXS-97 program. ${ }^{63}$ The refinements were carried out by full-matrix anisotropic least-squares on $F^{2}$ for all reflections for non-H atoms by means of the SHELXL-97 program. ${ }^{64}$ Crystallographic data (excluding structure factors) concerning the structures solved in this paper have been deposited with the Cambridge Crystallographic Data Centre as supplementary publication nos. CCDC 1437490 (7p), 1437488 (7s), 1437489 (7t), 1437487 (10a), 1437486 (10b), and 1446645 (10c). Copies of the data can be obtained, free of charge, on application to CCDC, 12 Union Road, Cambridge CB2 1EZ, UK; (fax: + 44 (0) 1223336 033; or e-mail: deposit@ccdc.cam.ac.uk).

Radioligand Binding Studies in Native Bovine and Human Cerebral Receptors. $\left[{ }^{3} \mathrm{H}\right]$ Flumazenil (specific activity $70.8 \mathrm{Ci} /$ mmol) was obtained from PerkinElmer Life Science (Milano, Italy). All other chemicals were at reagent grade and were obtained from commercial suppliers.

Bovine cortex was obtained from the local slaughterhouse. Human cortex samples were taken post-mortem at the Department of Pathological Anatomy, University of Pisa, during autopsy sessions. The subjects had died from causes not primarily involving the brain and had not suffered from any psychiatric or neurological disorders.
The time between death and tissue dissection/freezing ranged from 18 to $36 \mathrm{~h}$. The samples were immediately packed in dry ice and stored in a $-80^{\circ}$ freezer. The study was approved by the Ethics Committee of the University of Pisa, Italy.

Bovine and human cerebral cortex membranes were prepared in agreement with Martini et al. ${ }^{65}$ Briefly, cerebral cortex was homogenized in 10 volumes of ice cold $0.32 \mathrm{M}$ sucrose containing protease inhibitors. The homogenate was centrifuged at $1000 \mathrm{~g}$ for 10 min at $4{ }^{\circ} \mathrm{C}$, the resulting pellet was discarded, and the supernatant was recentrifuged at $48000 \mathrm{~g}$ for $15 \mathrm{~min}$ at $4{ }^{\circ} \mathrm{C}$. Then the pellet was osmotically shocked by suspension in 10 volumes of $50 \mathrm{mM}$ Triscitrate buffer at $\mathrm{pH} 7.4$ containing protease inhibitors and recentrifuged at $48000 \mathrm{~g}$ for $15 \mathrm{~min}$ at $4{ }^{\circ} \mathrm{C}$. The resulting membranes were frozen and washed by means of the procedure previously described for removing endogenous GABA from cerebral cortex. ${ }^{66}$ Finally, the pellet was suspended in 10 volumes of $50 \mathrm{mM}$ Tris-citrate buffer $\mathrm{pH} 7.4$ and used in the binding assay. Protein concentration was assayed by the method of Lowry et al. ${ }^{67}$ by means of bovine serum albumin as the standard.

$\left[{ }^{3} \mathrm{H}\right]$ Flumazenil binding studies were performed as previously reported. ${ }^{68}$ The $\left[{ }^{3} \mathrm{H}\right]$ flumazenil binding was performed in triplicate by incubating aliquots of the membrane fractions $(0.2-0.3 \mathrm{mg}$ of protein) at $0{ }^{\circ} \mathrm{C}$ for $90 \mathrm{~min}$ in $0.5 \mathrm{~mL}$ of $50 \mathrm{mM}$ Tris-citrate buffer, $\mathrm{pH} 7.4$, with approximately $0.2 \mathrm{nM}\left[{ }^{3} \mathrm{H}\right]$ flumazenil. Nonspecific binding was defined in the presence of $10 \mu \mathrm{M}$ diazepam. After incubation, the samples were diluted at $0{ }^{\circ} \mathrm{C}$ with $5 \mathrm{~mL}$ of the assay buffer and immediately harvested onto GF/B filters (Brandel) by means of a harvester and washed with ice-cold assay buffer. The filters were washed twice with $5 \mathrm{~mL}$ of the buffer, dried, and $4 \mathrm{~mL}$ of Ready Protein Beckman scintillation cocktail added; radioactivity was counted in a Packard LS 1600 liquid-phase scintillation $\beta$ counter.

The compounds were routinely dissolved into DMSO and added to the assay mixture to amount to a final volume of $0.5 \mathrm{~mL}$. Blank experiments were carried out to determine the effect of the solvent (2\%) on binding. At least six different concentrations spanning 3 orders of magnitude, adjusted approximately for the $\mathrm{IC}_{50}$ of each compound, were used. $\mathrm{IC}_{50}$ values were calculated by a nonlinear formula on a computer program (GraphPad, San Diego, CA) and converted into the corresponding $K_{\mathrm{i}}$ values by the Cheng and Prusoff equation with the $K_{\mathrm{d}}$ values of the radioligand in these different tissues already known. ${ }^{69}$ The $K_{\mathrm{d}}$ of $\left[{ }^{3} \mathrm{H}\right]$ flumazenil binding to cortex membrane from bovine and human was 0.85 and $0.91 \mathrm{nM}$, respectively. The GABA ratio was determined by calculating $K_{\mathrm{i}}$ without $\mathrm{GABA} / K_{\mathrm{i}}$ with GABA $50 \mu \mathrm{M}$ for each compound.

In Vitro Efficacy in ${ }^{36} \mathrm{Cl}^{-}$Uptake Assay in Rat Cerebrocortical Synaptoneurosomes. ${ }^{36} \mathrm{Cl}^{-}$(specific activity $9.69 \mu \mathrm{Ci} / \mathrm{g}$ ) was obtained from PerkinElmer Life Science (Milan, Italy). All other chemicals were reagent grade and were obtained from commercial suppliers.

The ${ }^{36} \mathrm{Cl}^{-}$uptake was measured in rat cerebrocortical synaptoneurosomes as described by Schwartz et al., ${ }^{48}$ with minor modifications. Briefly, the cerebral cortex was dissected from Sprague-Dawley male rats suspended 1:10 with ice-cold solution containing $145 \mathrm{mM} \mathrm{NaCl}, 5$ $\mathrm{mM} \mathrm{KCl}, 5 \mathrm{mM} \mathrm{MgCl} 2,1 \mathrm{mM} \mathrm{CaCl}, 10 \mathrm{mM}$ HEPES, pH 7 (T1 buffer), and $10 \mathrm{mM}$ D-glucose; they were homogenized with a glassglass homogenizer (five strokes) and filtered through three layers of nylon mesh $(160 \mu \mathrm{m})$ and a $10 \mu \mathrm{m}$ Millipore filter. The filtrates were centrifuged at $1000 \mathrm{~g}$ for $15 \mathrm{~min}$. After discarding the supernatant, the pellet was gently resuspended in $\mathrm{T} 1$ buffer and washed once more by centrifugation ( $1000 \mathrm{~g}$ for $15 \mathrm{~min}$ ). The final pellet containing the synaptoneurosomes was suspended 1:2 in T1 buffer and kept on ice until ready for assay (no longer than $30 \mathrm{~min}$ ).

Aliquots of synaptoneurosome suspensions (1.5-2 mg of protein) were preincubated at $30^{\circ} \mathrm{C}$ for $10 \mathrm{~min}$ prior to the addition of $0.2 \mu \mathrm{Ci}$ of ${ }^{36} \mathrm{Cl}^{-}$. Drugs were added simultaneously with the ${ }^{36} \mathrm{Cl}^{-}(0.35 \mathrm{~mL}$ total assay volume). ${ }^{36} \mathrm{Cl}^{-}$uptake was stopped $10 \mathrm{~s}$ later by the addition of $5 \mathrm{~mL}$ of ice-cold HEPES, followed by vacuum filtration through glass fiber filters (Whatman GF/B) that had been soaked with $0.05 \%$ polyethylenimine to reduce nonspecific binding of ${ }^{36} \mathrm{Cl}^{-}$. The filters were washed three more times with $5 \mathrm{~mL}$ of ice-cold buffer and 
placed into scintillation vials containing $4 \mathrm{~mL}$ of Ready Protein Beckman scintillation cocktail, and radioactivity was counted in a Packard LS 1600 liquid-phase scintillation $\beta$ counter. Data are expressed as percent stimulation of ${ }^{36} \mathrm{Cl}^{-}$uptake above basal level.

In Vitro Efficacy in Excitotoxic-Mediated Injury. Compounds. Trizma base, ascorbic acid, sodium pyruvate, sodium EGTA, $\beta$ nicotinamide adenine dinucleotide $(\mathrm{NAD}+), \beta$-nicotinamide adenine dinucleotide reduced form (NADH), and all artificial cerebrospinal fluid (ACSF) components were purchased from Sigma-Aldrich Co. (St Louis, MO, U.S.A.). Drugs molecules were solubilized into DMSO and diluted at the final desired concentration with ACSF immediately before the experiment. Final DMSO concentration in the ACSF used for the experiments was always lower than $0.1 \%$, and this had no effect per se on the biochemical parameters investigated. ${ }^{54,59}$ All other materials were from standard local commercial sources and of the highest grade available.

Animals. All animal care and experimental protocols were in strict compliance with the European Union Guidelines for the Care and the Use of Laboratory Animals (the European Union Directive 2010/63/ EU) and were approved by the Italian Department of Health (813/ 2015-PR).

Sprague-Dawley male rats (300-350 g; Charles River Italia, Calco, Italy) were kept in large cages under a 12:12 h day-night cycle at 20 ${ }^{\circ} \mathrm{C}$ ambient temperature. Drinking water and conventional laboratory rat food were available ad libitum. Before sacrifice, animals were anaesthetized by intraperitoneal injection of a mixture of Ketavet (30 $\mathrm{mg} / \mathrm{kg}$ ketamine; Gellini, Aprilia, Italy) and xylazine $(8 \mathrm{mg} / \mathrm{kg}$ Xilor; Bayer AG, Wuppertal, Germany).

Preparation of Slices. After the sacrifice of the animal (by decapitation) the whole brain was rapidly removed, chilled to $4{ }^{\circ} \mathrm{C}$ by immersion into cold ACSF (composition in mM: $120 \mathrm{NaCl}, 2.5 \mathrm{KCl}$, $1.3 \mathrm{MgCl}_{2}, 1.0 \mathrm{NaH}_{2} \mathrm{PO}_{4}, 1.5 \mathrm{CaCl}_{2}, 26 \mathrm{NaHCO}_{3}, 11$ glucose, saturated with $95 \% \mathrm{O}_{2}-5 \% \mathrm{CO}_{2}$, with a final $\mathrm{pH}$ of 7.4 , osmolality 285-290 mOsmol). The cortex was dissected and cut into $400 \mu \mathrm{m}$ thick slices by using a manual chopper (Stoelting Co., Wood Dale, IL, USA). Afterward, slices were maintained in oxygenated ACSF enriched with $400 \mu \mathrm{M}$ ascorbic acid for $1 \mathrm{~h}$ at room temperature to allow maximal recovery from slicing trauma. ${ }^{59}$

In Vitro Ischemia-Like Conditions. Cortical slices from a single brain were placed in covered incubation flasks containing ACSF (2 $\mathrm{mL}$ ) continuously bubbled with a $95 \% \mathrm{O}_{2}-5 \% \mathrm{CO}_{2}$ gas mixture and incubated at $37{ }^{\circ} \mathrm{C}$ for an additional period of $30 \mathrm{~min}$. Afterward, OGD was carried out by incubating slices for $30 \mathrm{~min}$ into ACSF in which glucose was replaced by an equimolar amount of sucrose and continuously bubbled with a $95 \% \mathrm{~N}_{2}-5 \% \mathrm{CO}_{2}$ gas mixture. After the OGD phase, the ischemic-like solution was replaced by fresh, oxygenated ACSF for an additional $90 \mathrm{~min}$ period (reoxygenation phase). The protective effect of the tested compounds was investigated by adding them to ACSF during the entire reoxygenation phase.

Assessment of Tissue Injury. Cell damage was assessed by measuring the amount of $\mathrm{LDH}$ released into the ACSF during the entire reperfusion period. ${ }^{54,59} \mathrm{LDH}$ activity was determined spectrophotometrically via the rate of decrease in absorbance at 340 $\mathrm{nm}$ of $\mathrm{NADH}$ during its oxidation to $\mathrm{NAD}^{+}$and the concomitant reduction of pyruvate to lactate.

Data Analysis. Each experimental block was performed by using brain slices derived from at least four rats. The data are reported as mean \pm SEM, and statistical analysis was performed by using one-way ANOVA followed by Dunnet post-test (GraphPad Software, San Diego, CA, USA). In all comparisons, the level of statistical significance $(P)$ was set at 0.05 .

In Vivo Efficacy. The experiments were carried out in accordance with the Animal Protection Law of the Republic of Italy, DL No. 116/ 1992, based on the European Communities Council Directive of November 24, 1986 (86/609/EEC). All efforts were made to minimize animal suffering and to reduce the number of animals involved. Male CD-1 albino mice (22-24 g) and male Swiss Webster (20-26 g) (Morini, Italy) were used. Twelve mice were housed per cage and fed a standard laboratory diet, with tap water ad libitum for $12 \mathrm{~h} / 12 \mathrm{~h}$ light-dark cycles (lights on at 7:00). The cages were brought into the experimental room the day before the experiment for acclimatization purposes. All experiments were performed between 10:00 and 15:00.

Rota-rod Test. The integrity of the animals' motor coordination was assessed using a Rota-rod apparatus (Ugo Basile, Varese, Italy) at a rotating speed of $16 \mathrm{rpm}$. The treatment was performed before the test. The numbers of falls from the rod were counted for $30 \mathrm{~s}, 30 \mathrm{~min}$ after drug administration, and the test was performed according to the method described by Vaught et al. ${ }^{70}$

Light-Dark Box Test. The apparatus $(50 \mathrm{~cm}$ long, $20 \mathrm{~cm}$ wide, and $20 \mathrm{~cm}$ high) consisted of two equal acrylic compartments, one dark and one light, illuminated by a $60 \mathrm{~W}$ bulb lamp and separated by a divider with a $10 \mathrm{~cm} \times 3 \mathrm{~cm}$ opening at floor level. Each mouse was tested by placing it in the center of the lighted area, away from the dark one, and allowing it to explore the novel environment for $5 \mathrm{~min}$. The number of transfers from one compartment to the other and the time spent in the illuminated side were measured. This test exploited the conflict between the animal's tendency to explore a new environment and its fear of bright light. ${ }^{71}$

Passive-Avoidance Test. The test was performed according to the step-through method described by Jarvik et al. ${ }^{72}$ The apparatus consisted of a two-compartment acrylic box with a lighted compartment connected to a darkened one by a guillotine door. As soon as the mouse entered the dark compartment, it received a thermal shock punishment. The latency times for entering the dark compartment were measured in the training test and after $24 \mathrm{~h}$ in the retention test. The maximum entry latency allowed in the training and retention sessions was, respectively, 60 and $180 \mathrm{~s}$.

Hole-Board Test. The hole-board test consisted of a $40 \mathrm{~cm}^{2}$ plane with 16 flush-mounted cylindrical holes $(3 \mathrm{~cm}$ diameter) distributed four by four in an equidistant, grid-like manner. Mice were placed on the center of the board one by one and allowed to move about freely for a period of $5 \mathrm{~min}$ each. Two electric eyes, crossing the plane from midpoint to midpoint of the opposite sides, thus dividing the plane into four equal quadrants, automatically signaled the movement of the animal (counts in $5 \mathrm{~min}$ ) on the surface of the plane (spontaneous motility). Miniature photoelectric cells in each of the 16 holes recorded (counts in $5 \mathrm{~min}$ ) the exploration of the holes (exploratory activity) by the mice. A total of $12-15$ mice per group were tested. ${ }^{73}$

Compound Administration. Diazepam (Valium 10, Roche) was dissolved into isotonic $(\mathrm{NaCl}$ 0.9\%) saline solution and injected subcutaneously. The new compounds were administered by the po route and were suspended in $1 \%$ carboxymethylcellulose sodium salt and sonicated immediately before use. Drug concentrations were prepared in such a way that the necessary dose could be administered in a $10 \mathrm{~mL} / \mathrm{kg}$ volume of carboxymethylcellulose $1 \%$ by the per os or subcutaneous route.

Statistical Analysis. All experimental result are given as the mean \pm SEM. Each value represents the mean of 25 mice. An analysis of variance, ANOVA, followed by Fisher's protected least significant difference procedure for post hoc comparison, were used to verify significance between two means of behavioral results. The data were analyzed with the StatView software for Macintosh (1992). P values of less than 0.05 were considered significant.

\section{ASSOCIATED CONTENT}

\section{S Supporting Information}

The Supporting Information is available free of charge on the ACS Publications website at DOI: 10.1021/acs.jmedchem.6b00034.

Crystallographic structures of compounds $7 \mathbf{p}, \mathbf{s , t}$ and 10a-c (PDF) Molecular formula strings (CSV) 


\section{AUTHOR INFORMATION}

\section{Corresponding Authors}

*For A.C.: phone, +39 577 234320; fax, +39 0577 234333; Email, andrea.cappelli@unisi.it.

*For M.A.: phone, +39 577 234173; E-mail maurizio.anzini@ unisi.it.

\section{Notes}

The authors declare no competing financial interest.

\section{ACKNOWLEDGMENTS}

The authors are grateful to Dr. Francesco Berrettini (CIADS, Università di Siena) for the X-ray data collection and to Prof. Stefania D'Agata D'Ottavi for the careful reading of the manuscript.

\section{ABBREVIATIONS USED}

GABA, $\gamma$-aminobutyric acid; CBR, central benzodiazepine receptor; CNS, central nervous system; LGICs, ligand-gated ion channels; $\mathrm{BDZ}$, benzodiazepine; SAR, structure-activity relationship; TBDMSCl, tert-butyldimethylsilyl chloride; GR, GABA ratio; PD, Parkinson's disease; HD, Huntington's disease; OGD/R, oxygen-glucose deprivation and reoxygenation; LDH, lactate dehydrogenase; ACSF, artificial cerebrospinal fluid

\section{REFERENCES}

(1) Thompson, A. J.; Lester, H. A.; Lummis, S. C. R. The structural basis of function in Cys-loop receptors. Q. Rev. Biophys. 2010, 43, 449-499.

(2) Smith, G. B.; Olsen, R. W. Functional domains of $G_{A B A}$ receptors. Trends Pharmacol. Sci. 1995, 16, 162-168.

(3) Argyropoulos, S. V.; Nutt, D. J. The use of benzodiazepines in anxiety and other disorders. Eur. Neuropsychopharmacol. 1999, 9, S407-S412.

(4) Park-Chung, M.; Malayev, A.; Purdy, R. H.; Gibbs, T. T.; Farb, D. $\mathrm{H}$. Sulfated and unsulfated steroids modulate $\gamma$-aminobutyric acid receptor A function through distinct sites. Brain Res. 1999, 830, 7287.

(5) Rupprecht, R.; Holsboer, F. Neuroactive steroids: mechanisms of action and neuropsychoharmacological perspectives. Trends Neurosci. 1999, 22, 410-416.

(6) Dorow, R. FG7142 and its anxiety inducing effects in humans. Br. J. Clin. Pharmacol. 1987, 23, 781-782.

(7) Williams, T. J.; Bowie, P. E. Midazolam sedation to produce complete amnesia for bronchoscopy: 2 years' experience at a district general hospital. Respir. Med. 1999, 93, 361-365.

(8) Stewart, S. A. The effects of benzodiazepines on cognition. J. Clin. Psychiatry 2005, 66 (suppl 2), 9-13.

(9) Lister, R. G. The amnestic action of benzodiazepines in man Neurosci. Biobehav. Rev. 1985, 9, 87-94.

(10) Ghoneim, M. M.; Mewaldt, S. P. Benzodiazepines and human memory: a review. Anesthesiology 1990, 72, 926-938.

(11) Chambers, M. S.; Atack, J. R.; Broughton, H. B.; Collinson, N.; Cook, S.; Dawson, G. R.; Hobbs, S. C.; Marshall, G.; Maubach, K. A.; Pillai, G. V.; Reeve, A. J.; MacLeod, A. M. Identification of a novel, selective $\mathrm{GABA}_{\mathrm{A}} \alpha_{5}$ receptor inverse agonist which enhances cognition. J. Med. Chem. 2003, 46, 2227-2240.

(12) Sarter, M.; Bruno, J. P.; Berntson, G. G. Psychotogenic properties of benzodiazepine receptor inverse agonists. Psychopharmacology 2001, 156, 1-13.

(13) Dorow, R.; Horowski, R.; Paschelke, G.; Amin, M.; Braestrup, C. Severe anxiety induced by FG 7142, a $\beta$-carboline ligand for benzodiazepine receptors. Lancet 1983, 322, 98-99.

(14) Barnard, E. A.; Skolnick, P.; Olsen, R. W.; Molhler, H.; Sieghart, W.; Biggio, G.; Braestrup, C.; Bateson, A. N.; Langer, S. Z. International Union of Pharmacology. XV. Subtypes of $\gamma$-aminobutyric acid A receptors: classification on the basis of subunit structure and receptor function. Pharmcol. Rev. 1998, 50, 291-314.

(15) Knoflach, F.; Rhyner, T.; Villa, M.; Kellenberger, S.; Drescher, U.; Malherbe, P.; Sigel, E.; Mohler, H. The $\gamma 3$-subunit of the $\mathrm{GABA}_{\mathrm{A}^{-}}$ receptor confers sensitivity to benzodiazepine receptor ligands. FEBS Lett. 1991, 293, 191-194.

(16) Ernst, M.; Brauchart, D.; Boresch, S.; Sieghart, W. Comparative modeling of GABA-A receptor: limits, insights, future developments. Neuroscience 2003, 119, 933-943.

(17) McKernan, R. M.; Rosahl, T. W.; Reynolds, D. S.; Sur, C.; Wafford, K. A.; Atack, J. R.; Farrar, S.; Myers, J.; Cook, G.; Ferris, P.; Garrett, L.; Bristow, L.; Marshall, G.; Macaulay, A.; Brown, N.; Howell, O.; Moore, K. W.; Carling, R. W.; Street, L. J.; Castro, J. L.; Ragan, C. I.; Dawson, G. R.; Whiting, P. J. Sedative but not anxiolytic properties of benzodiazepines are mediated by the $\mathrm{GABA}_{\mathrm{A}}$ receptor $\alpha 1$ subtype. Nat. Neurosci. 2000, 3, 587-592.

(18) Rudolph, U.; Möhler, H. Analysis of $\mathrm{GABA}_{\mathrm{A}}$ receptor function and dissection of the pharmacology of benzodiazepines and general anaesthetics through mouse genetics. Annu. Rev. Pharmacol. Toxicol. 2004, 44, 475-498.

(19) Atack, J. R.; Hutson, P. H.; Collinson, N.; Marshall, G.; Bentley, G.; Moyes, C.; Cook, S. M.; Collins, I.; Wafford, K.; McKernan, R. M.; Dawson, G. R. Anxiogenic properties of an inverse agonist selective for $\alpha 3$ subunit-containing $\mathrm{GABA}_{\mathrm{A}}$ receptors. Br. J. Pharmacol. 2005, 144, $357-366$.

(20) Rudolph, U.; Knoflach, F. Beyond classical benzodiazepines: novel therapeutic potential of $\mathrm{GABA}_{\mathrm{A}}$ receptor subtypes. Nat. Rev. Drug Discovery 2011, 10, 685-697.

(21) Gill, K. M.; Lodge, D. J.; Cook, J. M.; Aras, S.; Grace, A. A. A novel $\alpha 5 \mathrm{GABA}_{\mathrm{A}} \mathrm{R}$-positive allosteric modulator revereses hyperactivation of the dopamine system in the MAM model of schizophrenia. Neuropsychopharmacology 2011, 36, 1903-1911.

(22) Cook, J. M.; Clayton, T. S.; Jain, H. D.; Johnson, Y.-T.; Yang, J.; Rallapalli, S. K.; Wang, Z.-J.; Namjoshi, O. A.; Poe, M. M.-J. Gabaergic receptor subtype selective ligands and their uses. US 20150258128A1, September 17, 2015

(23) Cook, J. M.; Clayton, T. S.; Jain, H. D.; Rallapalli, S. K.; Johnson, Y. T.; Yang, J.; Poe, M. M.-J.; Namjoshi, O. A.; Wang, Z.-J. Gabaergic receptor subtype selective ligands and their uses. US 20120295892A1, November 22, 2012.

(24) He, X.; Huang, Q.; Ma, C.; Yu, S.; McKernan, R.; Cook, J. M. Pharmacophore/receptor models for $\mathrm{GABA}_{\mathrm{A}} / \mathrm{BzR} \alpha 2 \beta 3 \gamma 2, \alpha 3 \beta 3 \gamma 2$, $\alpha 4 \beta 3 \gamma 2$ recombinant subtypes. Included volume analysis and comparison to $\alpha 1 \beta 3 \gamma 2, \alpha 5 \beta 3 \gamma 2$ and $\alpha 6 \beta 3 \gamma 2$ subtypes. Drug Des. Discovery 2000, 17, 131-171.

(25) Clayton, T. S.; Poe, M. M.; Rallapalli, S.; Biawat, P.; Savic, M. M.; Rowlett, J. K.; Gallos, G.; Emala, C. W.; Kaczorowski, C. C.; Stafford, D. C.; Arnold, L. A.; Cook, J. M. A Review of the updated pharmacophore for the alpha $5 \mathrm{GABA}_{\mathrm{A}}$ benzodiazepine receptor model. Int. J. Med. Chem. 2015, 2015, 430248 http//dx.doi.org/10. $1155 / 2015 / 430248$.

(26) Savic, M. M.; Milinkovic, M. M.; Rallapalli, S.; Clayton, T. S.; Joksimovic, S.; Van Linn, M.; Cook, J. M. The differential role of $\alpha 1$ and $\alpha 5$ - containing $\mathrm{GABA}_{\mathrm{A}}$ receptors in mediating diazepam effects on spontaneous locomotor activity and water-maze learning and memory in rats. Int. J. Neuropsychopharmacol. 2009, 12, 1179-1193.

(27) Drexler, B.; Zinser, S.; Huang, S.; Poe, M. M.; Rudolph, U.; Cook, J. M.; Antkowiak, B. Enhancing the function of alpha5containing $\mathrm{GABA}_{\mathrm{A}}$ receptors promotes action potential firing of neocortical neurons during up-states. Eur. J. Pharmacol. 2013, 703, $18-24$.

(28) Anzini, M.; Braile, C.; Valenti, S.; Cappelli, A.; Vomero, S.; Marinelli, L.; Limongelli, V.; Novellino, E.; Betti, L.; Giannaccini, G.; Lucacchini, A.; Ghelardini, C.; Norcini, M.; Makovec, F.; Giorgi, G.; Fryer, R. I. Ethyl 8-fluoro-6-(3-nitrophenyl)- $4 H$-imidazo[1,5-a][1,4]benzodiazepine-3-carboxylate as novel, highly potent and safe antianxiety agent. J. Med. Chem. 2008, 51, 4730-4743.

(29) Anzini, M.; Valenti, S.; Braile, C.; Cappelli, A.; Vomero, S.; Alcaro, S.; Ortuso, F.; Marinelli, L.; Limongelli, V.; Novellino, E.; Betti, 
L.; Giannaccini, G.; Lucacchini, A.; Daniele, S.; Martini, C.; Ghelardini, C.; Di Cesare Mannelli, L.; Giorgi, G.; Mascia, M. P.; Biggio, G. New insight into central benzodiazepine receptor-ligand interactions: design, synthesis, biological evaluation, and molecular modelling of 3-substituted 6-phenyl-4H-imidazo[1,5-a][1,4]benzodiazepines and related compounds. J. Med. Chem. 2011, 54, 5694-5711.

(30) Petke, J. D.; Im, H. K.; Im, W. B.; Blakeman, D. P.; Pregenzer, J. F.; Jacobsen, E. J.; Hamilton, B. J.; Carter, D. B. Characterization of functional interactions of imidazoquinoxaline derivatives with benzodiazepine- $\gamma$-aminobutyric $\operatorname{acid}_{\mathrm{A}}$. Mol. Pharmacol. 1992, 42, 294-301.

(31) TenBrink, R. E.; Im, W. B.; Sethy, V. H.; Tang, A. H.; Carter, D. B. Antagonist, partial agonist, and full agonist imidazo[1,5-a]quinoxaline amides and carbamates acting through the $\mathrm{GABA}_{\mathrm{A}} /$ benzodiazepine receptor. J. Med. Chem. 1994, 37, 758-768.

(32) Jacobsen, E. J.; TenBrink, R. E.; Stelzer, L. S.; Belonga, K. L.; Carter, D. B.; Im, H. K.; Im, W. B.; Sethy, V. H.; Tang, A. H.; VonVoigtlander, P. F.; Petke, J. D. High-affinity partial agonist imidazo[1,5-a]quinoxaline amides, carbamates, and ureas at the $\gamma$ aminobutyric acid A /benzodiazepine receptor complex. J. Med. Chem. 1996, 39, 158-175.

(33) Jacobsen, E. J.; Stelzer, L. S.; Belonga, K. L.; Carter, D. B.; Im, W. B.; Sethy, V. H.; Tang, A. H.; VonVoigtlander, P. F.; Petke, J. D. 3Phenyl-substituted imidazo[1,5-a]quinoxalin-4-ones and imidazo[1,5a] quinoxaline ureas that have high-affinity at the $\mathrm{GABA}_{\mathrm{A}}$ /benzodiazepine receptor complex. J. Med. Chem. 1996, 39, 3820-3836.

(34) Mickelson, J. W.; Jacobsen, E. J.; Carter, D. B.; Im, H. K.; Im, W. B.; Schreur, P. J. K. D.; Sethy, V. H.; Tang, A. H.; McGee, J. E.; Petke, J. D. High-affinity $\gamma$-aminobutyric acid A /benzodiazepine ligands: Synthesis and structure-activity relationship studies of a new series of tetracyclic imidazoquinoxalines. J. Med. Chem. 1996, 39, 4654-4666.

(35) Jacobsen, E. J.; Stelzer, L. S.; TenBrink, R. E.; Belonga, K. L.; Carter, D. B.; Im, H. K.; Im, W. B.; Sethy, V. H.; Tang, A. H.; VonVoigtlander, P. F.; Petke, J. D.; Zhong, W. Z.; Mickelson, J. W. Piperazine imidazo[1,5-a]quinoxaline ureas as high-affinity $\mathrm{GABA}_{\mathrm{A}}$ ligands of dual functionality. J. Med. Chem. 1999, 42, 1123-1144.

(36) Im, H. K.; Im, W. B.; Pregenzer, J. F.; Stratman, N. C.; VonVoigtlander, P. F.; Jacobsen, E. J. Two imidazoquinoxaline ligands for the benzodiazepine site sharing a second low-affinity site on rat $\mathrm{GABA}_{\mathrm{A}}$ receptors but with the opposite functionality. Br. J. Pharmacol. 1998, 123, 1490-1494.

(37) Zhong, W. Z.; Williams, M. G.; Branstetter, D. G. Toxicokinetics in drug development: an overview of toxicokinetic application in the development of PNU-101017, an anxiolytic drug candidate. Curr. Drug Metab. 2000, 1, 243-254.

(38) Cappelli, A.; Gallelli, A.; Manini, M.; Anzini, M.; Mennuni, L.; Makovec, F.; Menziani, M. C.; Alcaro, S.; Ortuso, F.; Vomero, S. Further studies on the interaction of the 5-hydroxytryptamine ${ }_{3}$ (5$\mathrm{HT}_{3}$ ) receptor with arylpiperazine ligands. Development of a new 5$\mathrm{HT}_{3}$ receptor ligand showing potent acetylcholinesterase inhibitory properties. J. Med. Chem. 2005, 48, 3564-3575.

(39) Cappelli, A.; Butini, S.; Brizzi, A.; Gemma, S.; Valenti, S.; Giuliani, G.; Anzini, M.; Mennuni, L.; Campiani, G.; Brizzi, V.; Vomero, $\mathrm{S}$. The interactions of the $5-\mathrm{HT}_{3}$ receptor with quipazine-like arylpiperazine ligands. The journey track at the end of the first decade of the third millennium. Curr. Top. Med. Chem. 2010, 10, 504-526.

(40) Nayyar, A.; Jain, R. Synthesis and anti-tuberculosis activity of 2,4-disubstituted quinolines. Indian J. Chem., Sect. B: Org. Chem. Incl. Med. Chem. 2008, 47B, 117-128.

(41) Yen, V. Q.; Buu-Hoi, N. P.; Xuong, N. D. Fluorinated isatins and some of their heterocyclic derivatives. J. Org. Chem. 1958, 23, $1858-1861$.

(42) Cappelli, A.; Anzini, M.; Vomero, S.; Canullo, L.; Mennuni, L.; Makovec, F.; Doucet, E.; Hamon, M.; Menziani, M. C.; De Benedetti, P. G.; Bruni, G.; Romeo, M. R.; Giorgi, G.; Donati, A. Novel potent and selective central $5-\mathrm{HT}_{3}$ receptor ligands provided with different intrinsic efficacy. 2. Molecular basis of the intrinsic efficacy of arylpiperazine derivatives at the central $5-\mathrm{HT}_{3}$ receptors. J. Med. Chem. 1999, 42, 1556-1575.
(43) Castan, F.; Schambel, P.; Enrici, A.; Rolland, F.; Bigg, D. C. H. $\mathrm{New}$ arylpiperazine derivatives with high affinity for $5-\mathrm{HT}_{3}$ receptor sites. Med. Chem. Res. 1996, 6, 81-101.

(44) Braestrup, C.; Nielsen, M.; Honoré, T.; Jensen, L. H.; Petersen, E. N. Benzodiazepine receptor ligands with positive and negative efficacy. Neuropharmacology 1983, 22, 1451-1457.

(45) Braestrup, C.; Nielsen, M. Benzodiazepine receptors. In Handbook of Psychopharmacology; Iversen, L. L., Iversen, S. D., Snyder, S. H., Eds.; Plenum Press: New York, 1983, Vol. 17, pp 285384.

(46) Fryer, R. I.; Rios, R.; Zhang, P.; Gu, Z. Q.; Basile, A. S.; Skolnick, P. Structure-activity relationships of 2-pyrazolo[4,3-c] quinoline-3ones and their $\mathrm{N}$ - and $\mathrm{O}$-methyl analogues at benzodiazepine receptors. Med. Chem. Res. 1993, 3, 122-130.

(47) Fryer, R. I. Ligand interactions at central benzodiazepine receptor. In Comprehensive Medicinal Chemistry; Hansch, C., Sammes, P. G., Taylor, J. B., Eds; Pergamon: Oxford, UK, 1990, 3, 539-566.

(48) Schwartz, R. D.; Suzdak, P. D.; Paul, S. M. $\alpha$-Aminobutyric acid (GABA) - and barbiturate-mediated ${ }^{36} \mathrm{Cl}^{-}$uptake in rat brain synaptoneurosomes: evidence for rapid desensitization of the GABA receptor-coupled chloride ion channel. Mol. Pharmacol. 1986, 30, 419-426.

(49) Im, H. K.; Im, W. B.; Hamilton, B. J.; Carter, D. B.; VonVoigtlander, P. F. Potentiation of GABA-induced chloride currents by various benzodiazepine site agonists with $\alpha_{1} \gamma_{2}, \beta_{2} \gamma_{2}$ and $\alpha_{1} \beta_{2} \gamma_{2}$ subtypes of cloned $\mathrm{GABA}_{\mathrm{A}}$ receptors. Mol. Pharmacol. 1993, 44, 866870.

(50) Kleppner, S. R; Tobin, A. J. GABA signalling: therapeutic targets for epilepsy, Parkinson's disease and Huntington's disease. Expert Opin. Ther. Targets 2001, 5, 219-239.

(51) Gajcy, K.; Lochyński, S.; Librowski, T. A role of GABA analogues in the treatment of neurological diseases. Curr. Med. Chem. 2010, 17, 2338-2347.

(52) Rissman, R. A.; De Blas, A. L.; Armstrong, D. M. GABA receptors in aging and Alzheimer's disease. J. Neurochem. 2007, 103, $1285-1292$.

(53) Lauterbach, E. C.; Victoroff, J.; Coburn, K. L.; Shillcutt, S. D.; Doonan, S. M.; Mendez, M. F. Psychopharmacological neuroprotection in neurodegenerative disease: assessing the preclinical data. J. Neuropsychiatry Clin. Neurosci. 2010, 22, 8-18.

(54) Ricci, L.; Valoti, M.; Sgaragli, G.; Frosini, M. Neuroprotection afforded by diazepam against oxygen/glucose deprivation-induced injury in rat cortical brain slices. Eur. J. Pharmacol. 2007, 561, 80-84.

(55) Sethy, V. H.; Wu, H.; Oostveen, J. A.; Hall, E. D. Neuroprotective effects of the $\mathrm{GABA}_{\mathrm{A}}$ receptor partial agonist $\mathrm{U}$ 101017 in 3-acetylpyridine-treated rats. Neurosci. Lett. 1997, 228, 4549.

(56) Hall, E. D.; Fleck, T. J.; Oostveen, J. A. Comparative neuroprotective properties of the benzodiazepine receptor full agonist diazepam and the partial agonist PNU-101017 in the gerbil forebrain ischemia model. Brain Res. 1998, 798, 325-329.

(57) Hall, E. D.; Andrus, P. K.; Fleck, T. J.; Oostveen, J. A.; Carter, D. B.; Jacobsen, E. J. Neuroprotective properties of the benzodiazepine receptor, partial agonist PNU-101017 in the gerbil forebrain ischemia model. J. Cereb. Blood Flow Metab. 1997, 17, 875-883.

(58) Muir, J. K.; Lobner, D.; Monyer, H.; Choi, D. W. GABA receptor activation attenuates excitotoxicity but exacerbates oxygenglucose deprivation-induced neuronal injury in vitro. J. Cereb. Blood Flow Metab. 1996, 16, 1211-1218.

(59) Contartese, A.; Valoti, M.; Corelli, F.; Pasquini, S.; Mugnaini, C.; Pessina, F.; Aldinucci, C.; Sgaragli, G.; Frosini, M. A novel CB2 agonist, COR167, potently protects rat brain cortical slices against OGD and reperfusion injury. Pharmacol. Res. 2012, 66, 555-563.

(60) Paolino, M.; Mennuni, L.; Giuliani, G.; Anzini, M.; Lanza, M.; Caselli, G.; Galimberti, C.; Menziani, M. C.; Donati, A.; Cappelli, A. Dendrimeric tetravalent ligands for the serotonin-gated ion channel. Chem. Commun. 2014, 50, 8582-8585. 
(61) Hino, K.; Kawashima, K.; Oka, M.; Nagai, Y.; Uno, H.; Matsumoto, J. A novel class of antiulcer agents. 4-Phenyl-2-(1piperazinyl)quinolines. Chem. Pharm. Bull. 1989, 37, 110-115.

(62) Cappelli, A.; Giuliani, G.; Anzini, M.; Riitano, D.; Giorgi, G.; Vomero, S. Design, synthesis, and structure-affinity relationship studies in $\mathrm{NK}_{1}$ receptor ligands based on azole-fused quinolinecarboxamide moieties. Bioorg. Med. Chem. 2008, 16, 6850-6859.

(63) Sheldrick, G. M. SHELXS-97, Rel. 97-2, A Program for Automatic Solution of Crystal Structures; Göttingen University, 1997.

(64) Sheldrick, G. M. SHELXL-97, Rel. 97-2, A Program for Crystal Structure Refinement; Göttingen University, 1997.

(65) Martini, C.; Lucacchini, A.; Ronca, G.; Hrelia, S.; Rossi, C. A. Isolation of putative benzodiazepine receptors from rat brain membranes by affinity chromatography. J. Neurochem. 1982, 38, 1519.

(66) Martini, C.; Rigacci, T.; Lucacchini, A. $\left[{ }^{3} \mathrm{H}\right]$ Muscimol binding site on purified benzodiazepine receptor. J. Neurochem. 1983, 41, $1183-1185$.

(67) Lowry, O. H.; Rosebrough, N. J.; Farr, A. L.; Randall, R. J. Protein measurement with the folin phenol reagent. J. Biol. Chem. 1951, 193, 265-275.

(68) Bertelli, L.; Biagi, G.; Giorgi, I.; Manera, C.; Livi, O.; Scartoni, V.; Betti, L.; Giannaccini, G.; Trincavelli, L.; Barili, P. L. 1,2,3Triazolo[1,5-a] quinoxalines: Synthesis and binding to benzodiazepine and adenosine receptors. Eur. J. Med. Chem. 1998, 33, 113-122.

(69) Cheng, Y. C.; Prusoff, W. H. Relationship between the inhibition constant $\left(\mathrm{K}_{\mathrm{i}}\right)$ and the concentration of inhibition which causes $50 \%$ inhibition $\left(\mathrm{IC}_{50}\right)$ of an enzyme reaction. Biochem. Pharmacol. 1973, 22, 3099-3108.

(70) Vaught, J.; Pelley, K.; Costa, L. G.; Setler, P.; Enna, S. J. A comparison of the antinociceptive responses to GABA-receptor agonist THIP and baclofen. Neuropharmacology 1985, 24, 211-216.

(71) Walsh, D. M.; Stratton, S. C.; Harvey, F. J.; Beresford, I. J.; Hagan, R. M. The anxiolytic-like activity of GR159897, a non-peptide $\mathrm{NK}_{2}$ receptor antagonist, in rodent and primate models of anxiety. Psychopharmacology 1995, 121, 186-191.

(72) Jarvik, M. E.; Kopp, R. An improved one-trial passive avoidance learning situation. Psychol. Rep. 1967, 21, 221-224.

(73) Guerrini, G.; Costanzo, A.; Ciciani, G.; Bruni, F.; Selleri, S.; Costagli, C.; Besnard, F.; Costa, B.; Martini, C.; De Siena, G.; Malmberg-Aiello, P. Benzodiazepine receptor ligands. 8: Synthesis and pharmacological evaluation of new pyrazolo $[5,1-c][1,2,4]$ benzotriazine-5-oxide 3- and 8-disubstituted: High affinity ligands endowed with inverse-agonist pharmacological efficacy. Bioorg. Med. Chem. 2006, 14, 758-775. 